\title{
VIABILIDADE ECONÔMICA DA IRRIGAÇÃO DO FEIJÃO-CAUPI NO ESTADO DO PIAUÍ
}

\section{FRANCISCO EDINALDO PINTO MOUSINHO}

Tese apresentada à Escola Superior de Agricultura "Luiz de Queiroz", Universidade de São Paulo, para a obtenção do título de Doutor em Agronomia, Área de Concentração: Irrigação e Drenagem.

\section{P I R A C I C A B A}

Estado de São Paulo - Brasil

Junho - 2005 


\section{VIABILIDADE ECONÔMICA DA IRRIGAÇÃO DO FEIJÃO-CAUPI NO ESTADO DO PIAUÍ}

\section{FRANCISCO EDINALDO PINTO MOUSINHO}

Engenheiro Agrônomo

Orientador: Prof. Dr. JOSÉ ANTONIO FRIZZONE

Tese apresentada à Escola Superior de Agricultura "Luiz de Queiroz", Universidade de São Paulo, para a obtenção do título de Doutor em Agronomia, Área de Concentração: Irrigação e Drenagem.

P I R A C I C A B A

Estado de São Paulo - Brasil

Junho - 2005 
Dados I nt er naci onai s de Cat al ogação na Publi cação ( $C I P$ ) DI VI SÃO DE BI BLI OTECA E DOCUMENTAÇÃO - ESALQI USP

Mousinho, Francisco Edinaldo Pinto

Viabilidade econômica da irrigação do feijão-caupi no Estado do Piauí / Francisco Edinaldo Pinto Mousinho. - - Piracicaba, 2005.

103 p. il.

Tese (doutorado) - - Escola Superior de Agricultura Luiz de Queiroz, 2005. Bibliografia.

1. Balanço hídrico 2. Cultivo irrigado 3. Cultivo de sequeiro 4. Feijão

5. Geoprocessamento 6. Simulação - Estatística 7. Zoneamento agrícola I. Título

CDD 635.652

"Permi tida a cópi a tot al ou parcial deste documento, desde que citada a fonte - O aut or" 
À minha esposa, Francilene e às minhas filhas, Cibele e Letice, pelo amor, incentivo e compreensão durante esta jornada.

\section{DEDICO}

Aos meus pais, José Mousinho e Céres, e à minha irmã Luciana, pelo apoio, carinho e confiança.

\section{OFEREÇO}


"Algo que aprendi em uma longa vida: toda nossa ciência, medida contra a realidade, é primitiva e infantil - e ainda assim, é a coisa mais preciosa que temos".

Albert Einstein 


\section{AGRADECIMENTOS}

A Deus, que nos ilumina e nos encoraja para superar os momentos difíceis.

À Universidade Federal do Piauí, pela oportunidade concedida por meio da liberação das atividades de docência.

À Escola Superior de Agricultura "Luiz de Queiroz”, Universidade de São Paulo, pela oportunidade de realização do curso.

À Embrapa Meio-Norte pela disponibilização de sua estrutura física para a realização do trabalho.

À CAPES - Coordenação de Aperfeiçoamento de Pessoal de Nível Superior, pela concessão da bolsa de estudo, indispensável à realização do curso.

Ao Professor Dr. José Antonio Frizzone, pelos valiosos ensinamentos, orientações e pela confiança em mim depositada.

Ao Pesquisador da Embrapa Meio-Norte, Dr. Aderson Soares de Andrade Júnior, pelas orientações, sugestões, incentivo e disponibilização dos dados necessários à realização do trabalho.

Ao Departamento de Engenharia Rural - ESALQ/USP, aos seus funcionários e ao seu corpo docente, especialmente aos professores: Dr. Sérgio Nascimento Duarte, Dr. Marcos Vinícius Follegatti, Dr. Tarlei Arriel Botrel e Dr. Rubens Duarte Coelho, pelos ensinamentos, críticas e sugestões que muito contribuíram para desenvolvimento do trabalho.

Aos amigos Marcos Emanuel, Madaíla, Edson Cabral, Lázara, Nildo, Luis Gonzaga, Cleide, Miguel Angel, Cristiane, Rodrigo e Priscylla pelo companheirismo e amizade. 
Aos colegas de curso, em especial, Marconi, Anamaria, Roberta, Cláudio, Tonny, Tales Miler, Rogério, José Alves Júnior, Miguel Ferreira, Boanerges, Cleomar, Antônio, Yanê, Ronaldo, Ralini e Márcio, pela saudável convivência.

Às estagiárias da Embrapa Meio-Norte, Clarice e Clescy, pela ajuda na realização dos balanços hídricos.

Aos demais amigos, familiares e a todos que, direta ou indiretamente, contribuíram para esta realização. 


\section{SUMÁRIO}

Página

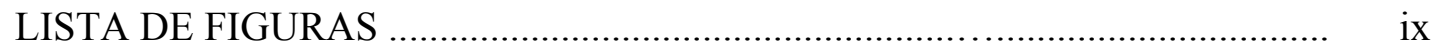

LISTA DE TABELAS ............................................................................. xiii

LISTA DE SÍMBOLOS, SIGLAS E ABREVIATURAS ….............................. xv

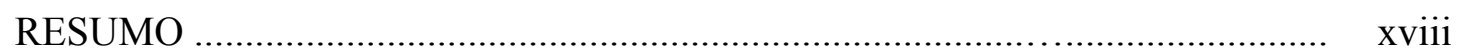

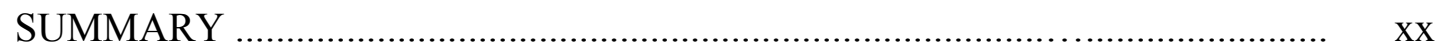

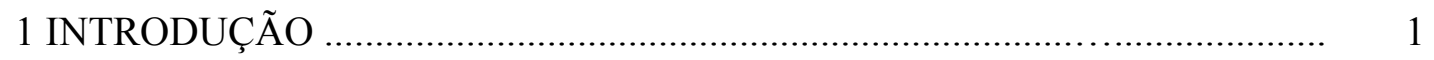

2 REVISÃO DE LITERATURA …........................................................... 3

$2.1 \mathrm{O}$ feijão-caupi - aspectos gerais .............................................................. 3

2.2 A água e o rendimento do feijão-caupi ..................................................... 5

2.3 Análise econômica sob condição de risco........................................................ 11

2.4 Espacialização de parâmetros agroclimáticos e econômicos.............................. 17

3 MATERIAL E MÉTODOS ...................................................................... 21

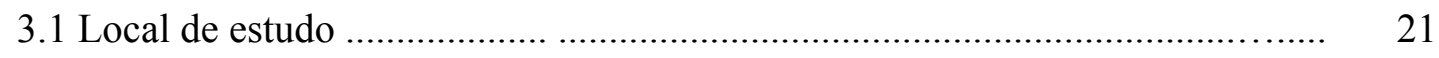

3.2 Precipitação pluviométrica .......................................................................... 22

3.3 Evapotranspiração de referência .................................................................. 23

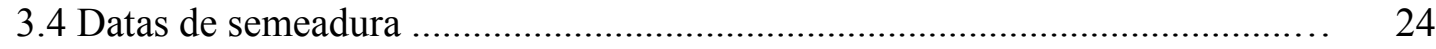

3.5 Parâmetros da cultura ............................................................................... 24

3.6 Parâmetros do solo ............................................................................................... 25

3.7 Balanço hídrico...................................................... 26

3.8 Rendimento relativo do feijão-caupi ......................................... 29

3.9 Simulação do rendimento relativo e lâmina bruta ........................... 31

3.10 Análise econômica sob condição de risco ............................. 32 
3.11 Espacialização das receitas líquidas ............................................................ 36

4 RESULTADOS E DISCUSSÃO ............................................ 39

4.1 CAD e viabilidade econômica da irrigação do feijão-caupi no estado do Piauí

4.2 Risco e viabilidade econômica da irrigação do feijão-caupi no estado do Piauí.....

4.3 Datas de semeadura e viabilidade econômica da irrigação do feijão-caupi no estado do Piauí

4.4 Locais de cultivo e viabilidade econômica da irrigação do feijão-caupi no estado do Piauí 48

5 CONCLUSÕES 54

ANEXOS 55

REFERÊNCIAS BIBLIOGRÁFICAS 80 APÊNDICE 98 


\section{LISTA DE FIGURAS}

Página

1 Localização geográfica dos postos pluviométricos onde foram obtidos os dados diários de precipitação pluviométrica

2 Representação da posição geográfica, em relação ao estado do Piauí, dos municípios referenciados nas Tabelas 4, 5, 6 e 7

3 Receitas líquidas (US\$ ha ${ }^{-1}$ ) obtidas com o cultivo irrigado do feijãocaupi no estado do Piauí, com semeadura em $1^{\mathrm{o}}$ de janeiro e diferentes níveis de risco $(\mathrm{R})$ e capacidade de água disponível no solo (CAD)

4 Receitas líquidas (US\$ ha ${ }^{-1}$ ) obtidas com o cultivo irrigado do feijãocaupi no estado do Piauí, com semeadura em $1^{\circ}$ de fevereiro e diferentes níveis de risco $(\mathrm{R})$ e capacidade de água disponível no solo $(\mathrm{CAD})$

5 Receitas líquidas (US\$ ha ${ }^{-1}$ ) obtidas com o cultivo irrigado do feijãocaupi no estado do Piaúí, com semeadura em $1^{\circ}$ de março e diferentes níveis de risco (R) e capacidade de água disponível no solo (CAD)

6 Receitas líquidas (US\$ ha ${ }^{-1}$ ) obtidas com o cultivo irrigado do feijãocaupi no estado do Piaú, com semeadura em $1^{\circ}$ de abril e diferentes níveis de risco $(\mathrm{R})$ e capacidade de água disponível no solo (CAD) 
7 Receitas líquidas (US\$ $\mathrm{ha}^{-1}$ ) obtidas com o cultivo irrigado do feijãocaupi no estado do Piauí, com semeadura em $1^{\circ}$ de maio e diferentes níveis de risco $(\mathrm{R})$ e capacidade de água disponível no solo (CAD)

8 Receitas líquidas (US\$ ha ${ }^{-1}$ ) obtidas com o cultivo irrigado do feijãocaupi no estado do Piauí, com semeadura em $1^{\circ}$ de junho e diferentes níveis de risco (R) e capacidade de água disponível no solo (CAD)

9 Receitas líquidas (US\$ ha ${ }^{-1}$ ) obtidas com o cultivo irrigado do feijãocaupi no estado do Piauí, com semeadura em $1^{\circ}$ de julho e diferentes níveis de risco $(\mathrm{R})$ e capacidade de água disponível no solo (CAD)

10 Receitas líquidas (US\$ ha ${ }^{-1}$ ) obtidas com o cultivo irrigado do feijãocaupi no estado do Piauí, com semeadura em $1^{\circ}$ de agosto e diferentes níveis de risco $(\mathrm{R})$ e capacidade de água disponível no solo (CAD)

11 Receitas líquidas (US\$ ha ${ }^{-1}$ ) obtidas com o cultivo irrigado do feijãocaupi no estado do Piauí, com semeadura em $1^{\circ}$ de setembro e diferentes níveis de risco $(\mathrm{R})$ e capacidade de água disponível no solo (CAD)

12 Receitas líquidas (US\$ ha ${ }^{-1}$ ) obtidas com o cultivo irrigado do feijãocaupi no estado do Piaú, com semeadura em $1^{\circ}$ de outubro e diferentes níveis de risco $(\mathrm{R})$ e capacidade de água disponível no solo (CAD)

13 Receitas líquidas (US\$ ha ${ }^{-1}$ ) obtidas com o cultivo irrigado do feijãocaupi no estado do Piauí, com semeadura em $1^{\circ}$ de novembro e diferentes níveis de risco $(\mathrm{R})$ e capacidade de água disponível no solo (CAD) 
14 Receitas líquidas (US\$ ha ${ }^{-1}$ ) obtidas com o cultivo irrigado do feijãocaupi no estado do Piauí, com semeadura em $1^{\circ}$ de dezembro e diferentes níveis de risco $(\mathrm{R})$ e capacidade de água disponível no solo (CAD)

15 Receitas líquidas (US\$ ha ${ }^{-1}$ ) obtidas com o cultivo de sequeiro do feijão-caupi no estado do Piaú, com semeadura em $1^{\circ}$ de janeiro e diferentes níveis de risco $(\mathrm{R})$ e capacidade de água disponível no solo (CAD)

16 Receitas líquidas (US\$ ha ${ }^{-1}$ ) obtidas com o cultivo de sequeiro do feijão-caupi no estado do Piaú́, com semeadura em $1^{\circ}$ de fevereiro e diferentes níveis de risco $(\mathrm{R})$ e capacidade de água disponível no solo (CAD)

17 Receitas líquidas (US\$ ha ${ }^{-1}$ ) obtidas com o cultivo de sequeiro do feijão-caupi no estado do Piaú́, com semeadura em $1^{\circ}$ de março e diferentes níveis de risco $(\mathrm{R})$ e capacidade de água disponível no solo (CAD)

18 Receitas líquidas (US\$ ha ${ }^{-1}$ ) obtidas com o cultivo de sequeiro do feijão-caupi no estado do Piauí, com semeadura em $1^{\circ}$ de abril e diferentes níveis de risco $(\mathrm{R})$ e capacidade de água disponível no solo (CAD)

19 Receitas líquidas (US\$ ha ${ }^{-1}$ ) obtidas com o cultivo de sequeiro do feijão-caupi no estado do Piaú́, com semeadura em $1^{\text {o }}$ de maio e diferentes níveis de risco $(\mathrm{R})$ e capacidade de água disponível no solo (CAD)

20 Receitas líquidas (US\$ ha ${ }^{-1}$ ) obtidas com o cultivo de sequeiro do feijão-caupi no estado do Piauí, com semeadura em $1^{\circ}$ de junho e diferentes níveis de risco $(\mathrm{R})$ e capacidade de água disponível no solo (CAD) 
21 Receitas líquidas (US\$ ha ${ }^{-1}$ ) obtidas com o cultivo de sequeiro do feijão-caupi no estado do Piaú, com semeadura em $1^{\circ}$ de julho e diferentes níveis de risco $(\mathrm{R})$ e capacidade de água disponível no solo (CAD)

22 Receitas líquidas (US\$ ha ${ }^{-1}$ ) obtidas com o cultivo de sequeiro do feijão-caupi no estado do Piaú, com semeadura em $1^{\circ}$ de agosto e diferentes níveis de risco $(\mathrm{R})$ e capacidade de água disponível no solo (CAD)

23 Receitas líquidas (US\$ ha ${ }^{-1}$ ) obtidas com o cultivo de sequeiro do feijão-caupi no estado do Piaú́, com semeadura em $1^{\circ}$ de setembro e diferentes níveis de risco $(\mathrm{R})$ e capacidade de água disponível no solo (CAD)

24 Receitas líquidas (US\$ ha ${ }^{-1}$ ) obtidas com o cultivo de sequeiro do feijão-caupi no estado do Piauí, com semeadura em $1^{\mathrm{o}}$ de outubro e diferentes níveis de risco $(\mathrm{R})$ e capacidade de água disponível no solo (CAD)

25 Receitas líquidas (US\$ ha ${ }^{-1}$ ) obtidas com o cultivo de sequeiro do feijão-caupi no estado do Piauí, com semeadura em $1^{\circ}$ de novembro e diferentes níveis de risco $(\mathrm{R})$ e capacidade de água disponível no solo (CAD)

26 Receitas líquidas (US\$ ha ${ }^{-1}$ ) obtidas com o cultivo de sequeiro do feijão-caupi no estado do Piaú́, com semeadura em $1^{\circ}$ de dezembro e diferentes níveis de risco $(\mathrm{R})$ e capacidade de água disponível no solo (CAD) 


\section{LISTA DE TABELAS}

Página

1 Coeficientes de cultivo $(\mathrm{Kc})$ para cada fase de desenvolvimento do feijão-caupi

2 Fator de resposta ao déficit hídrico (Ky) para cada fase de desenvolvimento do feijão-caupi

3 Percentuais da área do estado do Piauí ocupadas por diferentes classes de receita líquida (RL) obtidas com o cultivo de sequeiro do feijão-caupi em diferentes datas de semeadura, considerando a CAD de $40 \mathrm{~mm}$ e risco $75 \%$

4 Precipitação efetiva (Pef), lâmina bruta de irrigação necessária (Lb), rendimento simulado (RS), custo da energia (CE), custo total (CT) e receita líquida simulada (RL) para o cultivo irrigado do feijão-caupi em alguns locais do estado do Piauí com semeadura em $1^{\circ}$ de fevereiro, para uma CAD de $40 \mathrm{~mm}$ e um risco de $75 \%$

5 Precipitação efetiva (Pef), rendimento simulado (RS), custo da energia (CE), custo total (CT) e receita líquida simulada (RL) para o cultivo de sequeiro do feijão-caupi em alguns locais do estado do Piauí com semeadura em $1^{\circ}$ de fevereiro, para uma CAD de $40 \mathrm{~mm}$ e um risco de $75 \%$ 
6 Precipitação efetiva (Pef), lâmina bruta de irrigação necessária (Lb), rendimento simulado (RS), custo da energia (CE), custo total (CT) e receita líquida simulada (RL) para o cultivo irrigado do feijão-caupi em alguns locais do estado do Piauí com semeadura em $1^{\circ}$ de julho,

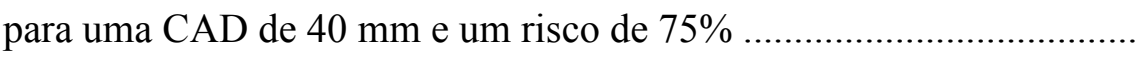

7 Precipitação efetiva (Pef), rendimento simulado (RS), custo da energia (CE), custo total (CT) e receita líquida simulada (RL) para o cultivo de sequeiro do feijão-caupi em alguns locais do estado do Piauí com semeadura em $1^{\circ}$ de julho, para uma de CAD $40 \mathrm{~mm}$ e um risco de $75 \%$ 


\section{LISTA DE SÍMBOLOS, SIGLAS E ABREVIATURAS}

$\lambda_{\mathrm{i}} \quad$ Fator de ponderação

$\mathrm{Z}_{\mathrm{Xo}}^{*} \quad$ Valor estimado da variável no local Xo

$\mathrm{Z}_{\mathrm{Xi}}^{*} \quad$ Valor da variável na posição vizinha $\mathrm{i}$, conhecida

$\hat{\gamma}(\mathrm{h}) \quad$ Semivariância

$\sigma \quad$ Desvio padrão da amostra

$\mu \quad$ Média da amostra

$\eta \quad$ Eficiência global do conjunto eletrobomba

$\gamma_{\mathrm{a}} \quad$ Peso específico da água

$\theta_{\mathrm{CC}} \quad$ Umidade do solo à capacidade de campo

$\theta_{\text {PMP }} \quad$ Umidade do solo no ponto de murcha permanente

AD Água disponível no solo

AFD Água facilmente disponível no solo

BHC Balanço hídrico de cultivo

C Custo de aquisição do equipamento de irrigação

CAD Capacidade de água disponível no solo

CE Custo da energia elétrica

CF Custo fixo de amortização

CP Custo de implantação da cultura

CTI Custo total de produção do feijão-caupi irrigado

CTS Custo total de produção do feijão-caupi de sequeiro 
DAS Dias após semeadura

Embrapa Empresa Brasileira de Pesquisa Agropecuária

$\mathrm{ET}_{0} \quad$ Evapotranspiração de referência

ETm Evapotranspiração máxima

ETr Evapotranspiração real

f Fração de esgotamento da água no solo

FAO Food and Agriculture Organization of the United Nations

FRC Fator de recuperação do capital

$\mathrm{Hm} \quad$ Altura manométrica total

I Lâmina bruta de irrigação

IBGE Instituto Brasileiro de Geografia e Estatística

INMET Instituto Nacional de Meteorologia

j Taxa anual de juros

Kc Coeficiente de cultivo

Ky $\quad$ Fator de resposta ao déficit hídrico

m Quantidade de número aleatórios gerados

n Vida útil do sistema de irrigação

N(h) Número de pares de dados separados por uma distância " $h$ "

Pef Precipitação efetiva

Pf Preço médio de venda do feijão-caupi

Pt Precipitação total

r Número aleatório gerado

RBI Receita bruta obtida pelo cultivo irrigado do feijão-caupi

RBS Receita bruta obtida pelo cultivo de sequeiro do feijão-caupi

RL Receita líquida

RLI Receita líquida obtida pelo cultivo irrigado do feijão-caupi

RLS Receita líquida obtida pelo cultivo de sequeiro do feijão-caupi

RS Rendimento relativo simulado

SIG Sistema de Informações Geográficas

SPRING Sistema de processamento de informações georeferenciadas 
SUDENE Superintendência de Desenvolvimento do Nordeste

Tc Tarifa de consumo de energia elétrica

YIr Rendimento real do feijão-caupi irrigado

Ym Produtividade máxima ou potencial da cultura

Yr Produtividade real da cultura

YSr Rendimento real do feijão-caupi cultivado em sequeiro

Z Profundidade efetiva do sistema radicular

$\mathrm{Z}(\mathrm{s}) \quad$ Valor da variável na posição "s"

$\mathrm{Z}(\mathrm{s}+\mathrm{h}) \quad$ Valor da variável em uma posição " $\mathrm{s}+\mathrm{h}$ " 


\title{
VIABILIDADE ECONÔMICA DA IRRIGAÇÃO DO FEIJÃO-CAUPI NO ESTADO DO PIAUÍ
}

\author{
Autor: FRANCISCO EDINALDO PINTO MOUSINHO \\ Orientador: Prof. Dr. JOSÉ ANTONIO FRIZZONE
}

\section{RESUMO}

O objetivo deste trabalho foi avaliar a viabilidade econômica da irrigação do feijão-caupi no estado do Piauí, utilizando técnicas de geoprocessamento. A partir de dados diários de precipitação pluviométrica, obtidos em 165 locais, e de valores diários de evapotranspiração de referência estimados para os mesmos locais pelo método de Thornthwaite (1948), realizou-se balanços hídricos de cultivo em escala diária para todos os anos das séries de dados pelo método de Thornthwaite \& Mather (1955), considerando-se o cultivo irrigado e de sequeiro do feijão-caupi, utilizando-se os parâmetros da cultura e três níveis de capacidade de água disponível no solo, 20 mm, 40 $\mathrm{mm}$ e $60 \mathrm{~mm}$, para doze datas de semeadura ao longo do ano, sendo estas fixadas no primeiro dia de cada mês. Estimou-se as lâminas brutas de irrigação necessárias durante o ciclo da cultura para a condição do cultivo irrigado e, através do déficit de evapotranspiração relativa obtida em cada balanço hídrico, obteve-se os rendimentos relativos para todas as combinações de cultivo, local, capacidade de água disponível no solo e data de semeadura. Utilizando-se o método de Monte Carlo foram simulados valores de rendimentos relativos e lâminas brutas de irrigação necessárias, para o cultivo irrigado, e valores de rendimento relativo, para o cultivo de sequeiro, para as mesmas combinações de local, data de semeadura e capacidade de água disponível no solo. A partir dos dados simulados foram estimados valores de rendimento relativo e lâminas brutas de irrigação, para as diversas situações, considerando-se os níveis de risco, 25\%, 
$50 \%$ e $75 \%$, sendo as receitas líquidas estimadas para estas mesmas situações e posteriormente espacializadas para o estado do Piauí e representadas por meio de mapas temáticos de receitas líquidas. $\mathrm{O}$ cultivo irrigado do feijão-caupi mostrou-se economicamente viável no estado do Piauí, independentemente da data de semeadura, $\mathrm{CAD}$ e grau de risco utilizados. As receitas líquidas variaram para as diversas regiões do estado do Piauí, em função da época de semeadura, CAD e nível de risco, especialmente para o cultivo de sequeiro. O cultivo de sequeiro do feijão-caupi mostrou-se viável para algumas combinações de local, data de semeadura, CAD e risco, estando mais condicionada à escolha dos locais e épocas de cultivo mais adequados, devido à variabilidade espacial e temporal das chuvas. Considerando-se uma estratégia de planejamento em nível estadual, a semeadura em $1^{\circ}$ de fevereiro foi a que se mostrou mais favorável, tanto para o cultivo irrigado quanto para o cultivo de sequeiro, pois proporcionou a obtenção de maiores valores de receitas líquidas, bem como maiores áreas do Estado ocupadas por estes. 


\title{
ECONOMIC FEASIBILITY OF COWPEA IRRIGATION IN THE PIAUI STATE
}

\author{
Author: FRANCISCO EDINALDO PINTO MOUSINHO \\ Adviser: Dr. JOSÉ ANTONIO FRIZZONE
}

\section{SUMMARY}

This study aimed at evaluating the economic feasibility of cowpea irrigation in the Piauí State by the use of geoprocessing techniques. Utilizing historical series of daily rainfall data, obtained at 165 different sites, daily reference evapotranspiration values estimated for the same sites by the Thornthwaite method (1948), and cowpea crop parameters as well as three levels of available water capacity in the soil, $20 \mathrm{~mm}, 40 \mathrm{~mm}$ and $60 \mathrm{~mm}$, the water balances were carried out in daily basis for all years of the series of data using the methodology proposed by Thornthwaite \& Mather (1955), considering irrigated and no irrigated crops, for twelve sowing dates along the year, being these fixed on the first day of every month. Based on the results of the crop water balance, it was estimated the gross irrigation depths during the cycle of the culture for the condition of the irrigated crop and based on the relative evapotranspiration deficit obtained in every water balance, it was estimated the relative incomes for irrigated and no-irrigated crops for all of the 165 studied places and for each combination of available water capacity in the soil and sowing dates. Values of relative incomes and gross depths of irrigation, for irrigated crop, and values of relative income for the no-irrigated crop for each place and for each combination of sowing date and available water capacity in the soil were simulated using the Monte Carlo's method. Values of relative income and gross irrigation depths for each place and for all situations, considering the risk levels of 
$25 \%, 50 \%$ and $75 \%$, were estimated based on the simulated data. The liquid incomes were estimated for all situations, and later it was spatialized for Piaui State and represented by thematic maps of liquid incomes. The irrigated cowpea crop was shown to be economically viable in the Piaui State, independently of the sowing date, available water capacity and the risk degree used. The liquid incomes varied for the several regions of Piaui State, as a consequence of the sowing date, available water capacity and risk level, especially for the no irrigated crop. The no irrigated cowpea crop was shown to be viable for some combinations of place, sowing date, available water capacity and risk, being more correlated to the choice of places and more suitable sowing dates, due to the spatial and temporal variability of the rains. Considering a planning strategy for Piaui State, for both the irrigated an no irrigated crop, the sowing on February 1 was the one that was shown to be more favorable, because it enabled higher values of liquid incomes and these values covered larger areas of the State. 


\section{INTRODUÇÃO}

A agricultura, em função dos fatores inerentes à planta, ao solo, ao clima e aos associados à economia, é uma atividade que apresenta um grau de risco relativamente alto. A disponibilidade hídrica é um dos fatores que mais contribuem para a ocorrência de riscos, principalmente nas regiões áridas e semi-áridas, por causa da irregularidade na distribuição temporal e espacial das chuvas, que condiciona a freqüência e a intensidade de períodos de déficit hídrico. Desta forma, a irrigação é uma prática necessária para se eliminar ou minimizar os riscos, suprindo a quantidade de água necessária para o adequado crescimento e desenvolvimento das plantas.

Dentre as diversas culturas, o feijão-caupi se destaca como uma das mais cultivadas na região Nordeste do Brasil, especialmente no estado do Piauí, sendo considerada a principal cultura de subsistência das populações da zona rural. Entretanto, os rendimentos obtidos com o seu cultivo ainda são extremamente baixos, geralmente inferiores a $300 \mathrm{~kg} \mathrm{ha}^{-1}$ (IBGE, 2002). A alta sensibilidade do feijoeiro ao déficit hídrico no solo, aliada às incertezas climáticas, principalmente as relacionadas com as variações pluviométricas entre anos e locais de cultivo, determinam esses baixos rendimentos e a oscilação da produção anual dessa cultura.

O conhecimento da demanda hídrica de uma cultura, baseando-se nas disponibilidades hídricas de diferentes regiões agroclimáticas, é de grande importância para um correto planejamento agrícola, tornando possível a regionalização do seu cultivo e a diminuição dos riscos, de modo a propiciar condições para a obtenção de elevados rendimentos.

Para a cultura do feijão-caupi, bons rendimentos de grãos têm sido obtidos quando o solo é mantido com um teor de água próximo à capacidade de campo. Desta 
forma, deve-se realizar um criterioso manejo do sistema solo-água-planta, de modo a se alcançar elevados retornos econômicos.

Alguns trabalhos de viabilidade econômica já foram realizados para a cultura do feijão-caupi. Entretanto, estes geralmente apresentam caráter local, sendo assim, de abrangência limitada. A espacialização de índices econômicos do desempenho dessa cultura, utilizando um sistema de informações geográficas, tem, então, uma grande importância, pois, regionalizando-se as informações, pode-se dispor de subsídios para um melhor planejamento e análise de alternativas para uma determinada região.

Por meio da utilização de dados de registros históricos de precipitação pluviométrica e evapotranspiração da cultura, pode-se ter, previamente, pela realização de um balanço de água no solo, as demandas totais e diárias de irrigação, em função da época e local de cultivo, bem como os retornos esperados e, através da espacialização destes parâmetros, pode-se planejar as datas de semeadura e regiões geográficas mais adequadas, possibilitando minimizar os riscos e garantir a sustentabilidade econômica da atividade agrícola.

Este trabalho teve por objetivo avaliar a viabilidade econômica da irrigação do feijão-caupi no estado do Piauí, considerando o risco climático advindo da irregularidade na distribuição temporal e espacial da precipitação pluviométrica, utilizando técnicas de geoprocessamento para a espacialização dos resultados. 


\section{REVISÃO DE LITERATURA}

\subsection{O feijão-caupi - considerações gerais}

O feijão-caupi (Vigna unguiculata (L.) Walp.) é uma leguminosa de ampla distribuição mundial, estando presente principalmente nas regiões tropicais do globo, pois estas têm características edafoclimáticas semelhantes ao seu provável berço de origem, a África. A FAO (2004) estima que no ano de 2003 foram cultivados no mundo cerca de 9,82 milhões de hectares de feijão-caupi, sendo que destes, aproximadamente 9,44 milhões de hectares foram cultivados na África. A produção mundial no mesmo ano foi de 3,72 milhões de toneladas de grãos secos, com um rendimento médio de $378 \mathrm{~kg} \mathrm{ha}^{-1}$, destacando-se a Nigéria como o maior produtor mundial, com 2,1 milhões de toneladas produzidas, seguida por Níger, que obteve uma produção de 0,4 milhão de toneladas.

No Brasil, embora os dados do IBGE (2002) referentes à produção nacional de feijão, englobem as espécies Vigna unguiculata e Phaseolus vulgaris, estima-se que são cultivados um pouco menos de 1,5 milhão de hectares de feijão-caupi. Devido às condições de adaptabilidade e do hábito alimentar da população, o feijão-caupi é cultivado predominantemente nas regiões Norte e Nordeste, alcançando, de 95\% a 100\% do total das áreas plantadas com feijão nos estados do Maranhão, Piauí, Ceará e Rio Grande do Norte (Santos et al., 2000). Vale ressaltar, que os valores referentes à área plantada e à produção nacional de feijão-caupi, apresentados pelo IBGE, divergem dos números da FAO (2004), mas representam a atual situação da produção nacional desta cultura. 
O estado do Ceará é o maior produtor nacional de feijão-caupi, seguido pelo Piauí. Na safra 2002/2003 a área plantada no Ceará foi de 618.600 hectares, resultando em uma produção de 211.800 toneladas, enquanto que, no Piaú, foram cultivados 218.100 hectares com uma produção de 68.500 toneladas (FNP, 2004).

O feijão-caupi, também conhecido como feijão-macassar ou feijão-de-corda, constitui-se na principal cultura de subsistência das regiões Norte e Nordeste do Brasil, especialmente no sertão nordestino. Essa cultura tem uma grande importância na alimentação das populações que vivem nessas regiões, principalmente as mais carentes, pois fornece um alimento de alto valor nutritivo, sendo um dos principais componentes da dieta alimentar, gerando, também, emprego e renda, tanto na zona rural quanto na zona urbana.

De acordo com Sales et al. (1988), o grão do feijão-caupi apresenta teores de proteínas variando de $20 \%$ a $26 \%$, apresentando importantes frações de lipídios, açúcares, cálcio, ferro, potássio, fósforo e aminoácidos essenciais como a isoleucina, leucina, fenilalanina, tirosina, metionina, dentre outros, com destaque para a última por estar presente em quantidades bem superiores ao feijão do gênero Phaseolus.

O feijão-caupi pode ser consumido na forma de vagem verde e grão, verde ou seco, além de outras formas de preparo. Para o consumo como vagem verde, a colheita é feita quando as vagens estão bem desenvolvidas, mas ainda com baixo teor de fibras. Para o consumo na forma de grãos verdes, as vagens são colhidas no início da maturação e para o consumo na forma de grão seco as vagens são colhidas secas, no ponto de maturação de campo (Vieira et al., 2000). Além da sua utilização na alimentação humana, o feijão-caupi pode, também, ser utilizado na alimentação animal, como forragem verde, feno, ensilagem e farinha, e ainda para adubação verde e cobertura do solo.

A planta do feijão-caupi apresenta flores completas, sendo os órgãos masculinos e femininos bem protegidos pelas pétalas, em número de cinco, de coloração branca, amarela ou violeta. Apresenta dez estames, sendo nove concrescidos, formando um tubo estaminal, e um livre. O estilete termina com um estigma recurvado, úmido e coberto de pêlos com a finalidade de aderir melhor os grãos de pólen. O ovário é estreito e alongado, 
com óvulos distribuídos em linha. A antese ocorre normalmente nas primeiras horas da manhã, condicionando a ocorrência da polinização, que se dá predominantemente através de insetos (Teófilo et al., 1999). O sistema radicular é pivotante, alcançando até $0,80 \mathrm{~m}$ de profundidade, tendo, como as demais leguminosas, a capacidade de fixação do nitrogênio do ar.

A cultura é bem adaptada às condições climáticas brasileiras, especialmente as da região Nordeste. De acordo com Oliveira \& Carvalho (1988), a temperatura mais adequada para o desenvolvimento do feijão-caupi encontra-se na faixa de $20^{\circ} \mathrm{C}$ a $30^{\circ} \mathrm{C}$. Altas temperaturas durante o florescimento podem ser prejudiciais à cultura, além de diminuir a nodulação nas raízes. Por outro lado, temperaturas abaixo de $20^{\circ} \mathrm{C}$ podem causar a paralisação do desenvolvimento das plantas.

No que se refere aos solos, o feijão-caupi pode ser cultivado em quase todos os tipos, especialmente nos Latossolos Amarelos, Latossolos Vermelho-Amarelos, Argissolos Vermelho-Amarelos e Neossolos Flúvicos. Em relação às características físicas e químicas do solo, como a maioria das culturas, desenvolve-se melhor naqueles ricos em matéria orgânica, com $\mathrm{pH}$ próximo de 6,0, textura média, profundos, bem drenados e de média a alta fertilidade. Todavia, outros solos, como os Latossolos e Neossolos Quartzarênicos, com baixa fertilidade, também podem ser utilizados, desde que sejam feitas as devidas correções de acidez e/ou fertilidade (Embrapa, 2003a).

\subsection{A água e o rendimento do feijão-caupi}

As exigências hídricas do feijoeiro, para a obtenção do máximo rendimento, variam de $300 \mathrm{~mm}$ a $400 \mathrm{~mm}$ durante o seu ciclo, dependendo das condições edafoclimáticas locais (Doorenbos \& Kassam, 2000).

Guimarães et al. (1996), verificaram que para a obtenção de elevadas produtividades de feijoeiro irrigado, foram necessárias aplicações de altas lâminas de água, superiores a $400 \mathrm{~mm}$. Guerra et al. (2000) trabalhando na região dos cerrados, em Planaltina-DF, obtiveram as mais altas produtividades de feijoeiro com a aplicação de lâminas em torno de $450 \mathrm{~mm}$ durante o ciclo da cultura. 
Nogueira \& Nogueira (1995), estudando a distribuição do sistema radicular do feijão-caupi em um solo arenoso nos Tabuleiros Costeiros do Piauí, avaliaram o efeito da aplicação de quatro lâminas de irrigação e três doses de fósforo sobre a produção de grãos da cv. BR-12 Canindé. Obtiveram a maior produtividade de grãos com a aplicação de uma lâmina de irrigação de $415,7 \mathrm{~mm}$ combinada com uma dose de fósforo de $180 \mathrm{~kg} \mathrm{ha}^{-1}$.

Rodrigues et al. (1999), avaliando a resposta de duas cultivares de feijão-caupi (BR-10 Piauí e BR-14 Mulato) à aplicação de quatro lâminas de irrigação (392,1mm; $335,9 \mathrm{~mm} ; 207,4 \mathrm{~mm}$ e $113,8 \mathrm{~mm}$ ), quanto ao rendimento de grãos e vagens verdes, nas condições edafoclimáticas de Parnaíba-PI, verificaram que, considerando a média das duas cultivares, os máximos rendimentos de vagens $\left(6.579 \mathrm{~kg} \mathrm{ha}^{-1}\right)$ e de grãos verdes (4.272 $\mathrm{kg} \mathrm{ha}^{-1}$ ) foram obtidos com a aplicação de uma lâmina de irrigação de 392,1 mm. Nas mesmas condições edafoclimáticas, Andrade et al. (1993) estimaram a evapotranspiração da cultura e o coeficiente de cultivo para o feijão-caupi cultivado na época do ano de maior demanda hídrica. Obtiveram valores de evapotranspiração da cultura variando de $5 \mathrm{~mm} \mathrm{dia}^{-1}$, no início do ciclo, a $9 \mathrm{~mm} \mathrm{dia}^{-1}$, aos 32 dias após o plantio, quando a cultura alcançou seu pleno desenvolvimento vegetativo. O consumo de água pela cultura em todo o seu ciclo foi de $380 \mathrm{~mm}$, correspondendo a um consumo médio de $6,3 \mathrm{~mm} \mathrm{dia}^{-1}$.

Andrade Júnior et al. (2002) obtiveram rendimentos de $2.809 \mathrm{~kg} \mathrm{ha}^{-1} \mathrm{e}$ $2.103 \mathrm{~kg} \mathrm{ha}^{-1}$ para as cultivares de feijão-caupi, BR-17 Gurguéia e BR-14 Mulato, respectivamente, em experimento realizado no litoral piauiense. Os referidos rendimentos foram obtidos com o emprego de 449,1 mm e 389,9 mm de água, respectivamente. Isso demonstra que o feijão-caupi, quando cultivado com um padrão de tecnologia para obtenção de altas produtividades, é uma planta bastante exigente em água.

Como as demais culturas, o rendimento do feijão é bastante afetado pela disponibilidade de água no solo. Deficiências ou excessos de água nas suas diferentes fases de desenvolvimento causam redução no seu rendimento em diferentes proporções (Silveira \& Stone, 1998). O déficit hídrico é um dos fatores que afetam a produção agrícola com maior freqüência e intensidade, influenciando praticamente todos os 
aspectos relacionados ao desenvolvimento vegetal, diminuindo a taxa de fotossíntese pela redução da área foliar e afetando vários outros processos, além de alterar o ambiente físico das culturas (Fontana et al., 1992). Seus efeitos dependem da sua intensidade, duração, época de ocorrência e da interação com outros fatores que interferem no rendimento das culturas (Cunha \& Bergamaschi, 1999).

Os efeitos do déficit hídrico são iniciados quando a evapotranspiração supera a taxa de absorção da água do solo pela cultura, estando associados à redução progressiva da disponibilidade de água no solo (Silveira \& Stone, 2001). A maioria das culturas apresenta períodos críticos quanto à deficiência hídrica, durante os quais a sua ocorrência pode causar grandes decréscimos no rendimento. A forma como o déficit hídrico se desenvolve na planta é bastante complexa, pois este afeta todos os aspectos relacionados ao seu desenvolvimento, sendo que os prejuízos estão diretamente relacionados à sua duração, severidade e do estágio de desenvolvimento da cultura (Follegatti et al., 1997).

De acordo com Andrade (1998), o feijoeiro apresenta profundidade efetiva do sistema radicular superficial, inferior a $0,40 \mathrm{~m}$. Portanto, a redução do conteúdo de água nas camadas superficiais do solo, causado por pequenos veranicos ou intervalos entre irrigações maiores, podem ser suficientes para a diminuição da disponibilidade hídrica para a cultura, reduzindo ou impedindo a absorção de água.

O conhecimento do desenvolvimento da cultura do feijão em função da água disponível no solo é de fundamental importância para se explicar as perdas de rendimento da cultura em condições de déficit hídrico (Leite et al., 1999). Desta forma, diversos trabalhos têm sido desenvolvidos procurando verificar o efeito dos déficits hídricos, nas diferentes fases de desenvolvimento, sobre o rendimento dessa cultura.

De acordo com Fancelli \& Dourado Neto (1999), a deficiência hídrica na fase de formação das vagens afeta o rendimento do feijoeiro pela redução da taxa de fotossíntese e do metabolismo da planta e pela queda e/ou diminuição do crescimento das vagens. Além do efeito direto sobre o desenvolvimento da cultura, o déficit hídrico leva à redução da eficiência de absorção de alguns nutrientes, como o nitrogênio e o fósforo.

Libardi (1996) verificou que a redução da disponibilidade hídrica durante o período reprodutivo do feijoeiro teve influência direta na redução do número de vagens 
por planta. Observou também, que a ocorrência de 10 e 17 dias de déficit hídrico na fase reprodutiva causou redução no rendimento de $42,6 \%$ e $62 \%$, respectivamente, quando comparadas à situação sem déficit hídrico.

Guimarães et al. (1996), observaram redução de 20\% no rendimento do feijoeiro quando ocorreram: 15 dias de déficit hídrico na pré-floração, 18 a 22 dias na floração e 15 dias na fase de enchimento de grãos. Massignam et al. (1998), em estudo para a determinação do período de desenvolvimento do feijoeiro mais crítico à deficiência hídrica, concluíram que este ocorre entre os seis dias antes e seis dias após a floração.

Cordeiro (1998) em estudo sobre a influência do déficit hídrico, em diferentes estágios fenológicos, sobre o rendimento do feijão-caupi, nas condições edafoclimáticas de Fortaleza-CE, verificou que a aplicação de déficit hídrico em apenas um estágio, provocou maior redução no rendimento quando ocorreu na fase de enchimento de grãos, sendo esta fase considerada a mais crítica. O déficit em dois estágios causou maior redução no rendimento quando aplicado nos estágios vegetativo e enchimento dos grãos. Quando o déficit foi aplicado em três estágios, causou a maior redução na produtividade, afetando significativamente a produtividade de grãos, o número médio de vagens por planta e o número médio de grãos por vagem.

Bastos et al. (2002), avaliando o crescimento e o desenvolvimento do feijão-caupi sob diferentes lâminas de irrigação, verificaram drástica redução da área foliar da cultura com o aumento do estresse hídrico.

Andrade Júnior et al. (2002) conduziram experimento nos Tabuleiros Costeiros do Piauí, visando avaliar o efeito da aplicação de quatro lâminas de água sobre o desempenho produtivo de duas cultivares de feijão-caupi (BR-17 Gurguéia e BR-14 Mulato), e constataram, também, efeito dos níveis de irrigação sobre o número de vagens por planta e produtividade de grãos das duas cultivares avaliadas.

Em um experimento conduzido em casa de vegetação em Areia-PB, utilizando a cultivar de feijão-caupi IPA-6, Nascimento et al. (2004) submeteram a cultura a quatro níveis de água disponível no solo $(40 \%, 60 \%, 80 \%$ e $100 \%$ da capacidade de água disponível no solo (CAD)) nas fases vegetativa e reprodutiva. Constataram que os níveis de deficiência hídrica influenciaram significativamente $(\mathrm{P}<0,01)$ o crescimento das 
plantas e a produção da cultura, sendo que os níveis de água disponível no solo de $40 \% \mathrm{e}$ $60 \%$ exerceram efeitos extremamente negativos sobre o rendimento da cultura, afetando especialmente o número de vagens por planta.

Lima (1996), verificando os resultados do efeito de cinco níveis de água disponível no solo sobre o crescimento e produtividade de duas cultivares de feijão-caupi (Pitiúba e João Paulo II), observou que o número de vagens por planta diminuiu com o aumento do déficit hídrico. A redução deste componente de produção foi o principal fator de decréscimo na produção de grãos de feijão-caupi.

Embora a fase reprodutiva do feijoeiro seja a mais sensível ao déficit hídrico, a sua ocorrência na fase vegetativa também reduz a produtividade dessa cultura, conforme constataram Stone \& Moreira (2001).

Carvalho et al. (2000), trabalhando em ambiente protegido em Lavras-MG, verificaram uma queda acentuada na produção do feijão-caupi à medida que o déficit hídrico no solo aumentou, independente da etapa fenológica em que este ocorreu. A queda foi mais acentuada quando o déficit ocorreu na fase de crescimento, atingindo uma produção nula no caso de déficit mais elevado (reposição de apenas $20 \%$ da água consumida). Para déficits hídricos de $80 \%$ e $20 \%$, ou seja, reposição de $20 \%$ e $80 \%$ da água consumida, as quedas de produção resultantes foram, respectivamente, $100 \%$ e $35 \%$ quando estes déficits ocorreram na fase de crescimento; $81 \%$ e $34 \%$ para os déficits ocorridos na etapa de floração e de $73 \%$ e $32 \%$ quando a deficiência hídrica ocorreu na fase de frutificação.

Bezerra \& Saunders (1992), avaliando o rendimento de cultivares de feijão-caupi submetidas a duas diferentes tensões de água no solo, no Vale do Curu-CE, verificaram que o rendimento médio de grãos diminuiu significativamente $(\mathrm{P}<0,05)$ com o potencial mátrico de água no solo. Obtiveram rendimentos de $1.503,7 \mathrm{~kg} \mathrm{ha}^{-1} \mathrm{e} 583,2 \mathrm{~kg} \mathrm{ha}^{-1}$, respectivamente, quando a tensão de água no solo foi mantida em $-40 \mathrm{kPa}$ e $-70 \mathrm{kPa}$. As evapotranspirações reais médias obtidas foram $4,3 \mathrm{~mm} \mathrm{dia}^{-1}$ e $3,4 \mathrm{~mm} \mathrm{dia}{ }^{-1}$, nos potenciais de $-40 \mathrm{kPa}$ e $-70 \mathrm{kPa}$, respectivamente.

Costa et al. (1997), avaliando o efeito do déficit hídrico imposto nas fases vegetativa (15 a 36 dias após a germinação) e reprodutiva (36 a 80 dias após a 
germinação), sobre a produção, componentes de produção e distribuição das raízes de feijão-caupi, cultivares Pitiúba, Setentão e Epace-10, cultivadas em casa de vegetação, verificaram que a deficiência hídrica na fase vegetativa determinou um adiamento do florescimento nas três cultivares. O número de vagens por planta, o número de flores por planta e o peso das vagens por planta foram reduzidos pelo déficit hídrico imposto nas duas fases.

Em experimento realizado na Fazenda Experimental Vale do Curu, em Pentecoste-CE, Cruz (1993) observou uma redução significativa do rendimento do feijãocaupi, quando submetido a déficit hídrico nas fases vegetativa e reprodutiva. Para as mesmas condições edafoclimáticas, Gondim et al. (2000), no intuito de determinar estratégias de manejo de água em feijão-caupi irrigado, verificaram que a época de maior consumo de água pelas plantas coincidiu com a floração e enchimento dos grãos.

Segundo Doorenbos e Kassam (2000), pode-se relacionar o rendimento de uma cultura e o suprimento de água, através da quantificação das suas necessidades hídricas e dos respectivos efeitos dos déficits hídricos sobre o seu rendimento. Citam ainda que, o estresse hídrico, representado pela deficiência relativa de evapotranspiração, e a produção relativa, são relacionados por meio de um coeficiente $(\mathrm{Ky})$, denominado de "fator de resposta da cultura". Esse coeficiente é variável em função das diferentes fases de desenvolvimento da cultura.

Os diferentes efeitos do déficit hídrico em cada fase de desenvolvimento de um cultura, traz como efeito indireto a variabilidade dos retornos econômicos obtidos para cada condição. Visando verificar esse efeito, estudos de análise econômica são importantes para o planejamento da atividade agrícola. Como exemplo, cita-se o trabalho de Cardoso et al. (1995) que realizaram uma análise agroeconômica da produção irrigada de sementes de feijão-caupi, cultivar BR-14 Mulato, nas condições edafoclimáticas de Teresina-PI e verificaram que a cultura apresentou uma elevada rentabilidade econômica, fornecendo uma relação benefício/custo de 4,78. 


\subsection{Análise econômica sob condição de risco}

De acordo com Francisco (1991), para a escolha da melhor alternativa de investimento, alguns indicadores podem ser usados, tais como as receitas, as despesas, o custo inicial, o valor residual e a vida útil econômica.

Frizzone (2005) classifica os critérios de análise econômica em dois grupos: 1) os que não consideram a variação do capital com o tempo e; 2) os que levam em consideração a variação que o capital sofre com o tempo. Como exemplo dos indicadores pertencentes ao primeiro grupo pode-se citar o tempo de retorno do capital investido e a relação receita/custo. $\mathrm{O}$ valor presente líquido, a taxa interna de retorno e a razão benefício/custo se enquadram no segundo grupo por considerarem a variação do capital com o tempo. O mesmo autor considera que os indicadores pertencentes ao segundo grupo, que se baseiam no fluxo de caixa, como a receita líquida, por exemplo, são os mais coerentes.

Embora não exista um método que permita conhecer antecipadamente, e com exatidão, os indicadores necessários para a análise econômica de um projeto ou atividade, a técnica da simulação e alguns princípios de decisão sob condições de risco, podem oferecer informações úteis para se incorporar a incerteza ao processo de análise de viabilidade econômica (Azevedo Filho, 1988).

Em regiões áridas e semi-áridas, a limitação da água é uma condição de grande importância para o planejamento da irrigação, sendo necessária a otimização do seu uso de modo a maximizar a receita líquida por unidade de volume de água utilizado (Calheiros et al., 1996). Estes mesmos autores, em estudo visando a obtenção de estratégias ótimas de irrigação do feijão considerando a água como fator limitante de produção, concluíram que a irrigação com déficit é uma estratégia importante no planejamento da irrigação, representando grande economia de água e capital, proporcionando produção e receitas líquidas satisfatórias.

O uso eficiente da água e a maximização da receita líquida do produtor, são cada vez mais necessários devido à disponibilidade hídrica cada vez menor e ao crescente aumento dos custos. De acordo com Algozin et al. (1988), estudos que envolvem 
estratégias de irrigação visando a otimização do uso da água, podem ser feitos tanto a partir de dados de campo, como através de simulações. Peiter (1998), relata que estudos a partir de dados de campo apresentam certas dificuldades, pois, de uma forma geral, são exigidas grandes áreas experimentais e diversas combinações de locais e épocas de cultivo, além das repetições anuais, gerando custos muito elevados. Assim, este autor destaca como alternativa a utilização da técnica da simulação, uma vez que por meio desta, pode-se testar diferentes estratégias de manejo, locais e épocas de cultivo, com significativa redução de tempo, mão-de-obra e recursos financeiros.

Andrade Júnior (2000) cita que a técnica da simulação pode ser empregada para a realização de estudos de análise de risco e previsão de fenômenos agroclimáticos e econômicos, onde possíveis valores podem ser obtidos a partir de uma série histórica. Esta característica é muito importante para estudos agroclimáticos, pois, na maioria dos casos, as séries de dados disponíveis são pequenas, o que poderia levar a obtenção de resultados tendenciosos (Genneville \& Boock, 1983).

A simulação pode ser realizada tanto através de modelos determinísticos quanto através de modelos estocásticos. Quando realizada através de um modelo estocástico, permite o cálculo de diferentes combinações que probabilisticamente poderiam ocorrer, obtendo-se como resultado não apenas um valor, mas uma distribuição de freqüência, onde o risco é representado pela variância (Brunelli, 1990; Dias, 1996; Frizzone \& Silveira, 2000).

Marchetti (1995) afirma que, na análise de investimentos produtivos, a abordagem determinística toma por base informações tidas como certas. Em conseqüência, fornece um único valor para as medidas de decisão, não incluindo uma estimativa quantitativa do risco. A abordagem probabilística, contrariamente, fornece como resultado uma distribuição de probabilidades das medidas de mérito, quantificando o risco envolvido.

A técnica da simulação é uma ferramenta altamente eficiente para a realização de estudos de rentabilidade econômica dos cultivos, tendo sido utilizada para estimar os rendimentos de culturas e avaliar níveis de manejo de irrigação apropriados sob condições de riscos climáticos. Trabalhos desse tipo foram desenvolvidos por Andrade 
Júnior (2000), que trabalhou com feijão-caupi e melancia nas condições edafoclimáticas dos Tabuleiros Costeiros e de Teresina, no Piauí, e Cardoso (2001), que trabalhou com o milho safrinha na região de Londrina-PR, dentre outros.

Dentre algumas técnicas de simulação existentes, destaca-se o método de Monte Carlo, que se baseia na comparação de números aleatórios com uma determinada função estatística, podendo ser ajustado à função de distribuição da variável em estudo, para a realização das simulações (Sousa, 1999; Frizzone, 2005). De acordo com Naylor et al. (1971), a metodologia Monte Carlo pode ser utilizada para simular não só a maioria das funções de probabilidade conhecidas, mas também as distribuições empíricas, onde os dados da variável em estudo não se ajustam a nenhuma distribuição de probabilidade teórica.

Diversos trabalhos foram realizados utilizando a simulação pelo método de Monte Carlo, sendo confirmada nestes a sua viabilidade e eficácia. Sousa \& Frizzone (1998) e Sousa (1999) utilizaram esta metodologia para a simulação de valores de evapotranspiração de referência e déficit de evapotranspiração e verificaram que os valores simulados mostraram-se bastante semelhantes aos valores observados, apresentando índices de concordância de Willmott e coeficientes de correlação superiores a 0,94 e 0,97, respectivamente, independente do número de simulações realizadas. Andrade Júnior (2000) utilizou a mesma metodologia para simular dados de chuva e evapotranspiração de referência diárias, em trabalho de análise de viabilidade econômica da irrigação nas microrregiões de Teresina e do Litoral Piauiense, constatando que a técnica simulou os referidos dados com precisão e exatidão. Biserra (1994) e Dias (1996), também utilizaram com sucesso a mesma técnica em estudos de análise de risco na avaliação de investimento em projetos e de custos de produção.

As estratégias de irrigação, devido às condições climáticas presentes na época e no local de cultivo, podem variar em função da água disponível no solo e do manejo da irrigação imposto à cultura. A estratégia ótima é aquela que maximiza a receita liquida do produtor e geralmente é diferente daquela que maximiza o rendimento físico da cultura. Porém, considerando-se o risco associado à atividade agrícola, principalmente devido às variações climáticas, a estratégia ótima pode não ser aquela que maximiza a receita 
líquida, mas sim, aquela que possibilite um determinado retorno do investimento ao produtor, com um menor risco.

Para Fancelli \& Dourado Neto (1999) a viabilidade da irrigação se dá pela minimização dos riscos e estabilização dos rendimentos, ocorrendo quando o fator limitante for a água e/ou preço de venda dos produtos. Sendo a água o fator limitante, deve-se levar em consideração a demanda hídrica, a ocorrência das chuvas e o nível de rendimento esperado.

Bastos et al. (2000) realizaram um estudo para identificar o nível de manejo econômico da irrigação do feijão-caupi para as condições edafoclimáticas de Teresina e Parnaíba-PI, via modelo de simulação, considerando cinco níveis de umidade do solo e quatro épocas de semeadura. Para o cultivo em Parnaíba, onde o solo era arenoso, observaram que as máximas receitas líquidas foram obtidas quando o reinício da irrigação se dava quando o solo apresentava um teor de umidade correspondente a $40 \%$ a $50 \%$ da CAD. Para o cultivo em Teresina, em um solo com maior capacidade de retenção de água, observaram que as máximas receitas líquidas foram obtidas quando o reinício da irrigação se dava quando o solo apresentava 30\% da CAD. Verificaram, também, que as receitas líquidas foram positivas para os dois locais em diversas épocas de semeadura.

Andrade Júnior (2000), em estudo da viabilidade econômica da irrigação nas microrregiões de Teresina e Litoral Piauiense, verificou que, para a cultura do feijãocaupi, o resultado econômico do cultivo irrigado foi melhor na microrregião de Teresina, independentemente da data de semeadura, nível de manejo de irrigação e risco, pois, neste local, o solo apresentava uma maior capacidade de retenção de água, sendo que as receitas líquidas foram maiores quando as irrigações foram mais freqüentes.

Segundo Bogges \& Ritchie (1988), a variabilidade climática, a resposta das culturas à água e as variações nos custos são fatores que muito contribuem para a ocorrência de um nível de risco inaceitável associado aos benefícios da irrigação.

No momento de um agricultor tomar a decisão com base apenas na obtenção da receita líquida máxima, este seria classificado como neutro em relação ao risco. 
Entretanto, esta não é a atitude esperada para um agricultor, pois estes são normalmente aversos ao risco ( Friedman \& Savage ${ }^{1}$, citados por Peres \& Matos, 1990)

Os riscos e as incertezas são inerentes à atividade agrícola e provém de fatores relacionados às incertezas do mercado e das oscilações de fatores climáticos, principalmente a chuva. O nível de risco pode ser diminuído pela irrigação (Franke, 1990), planejamento agrícola (Matzenauer et al., 1989), diversificação e rotação de culturas (Silva \& Dhein, 1994) ou melhorando o manejo das informações meteorológicas disponíveis.

Com a introdução do risco na teoria da produção, informações econômicas sobre novas tecnologias geradas pela pesquisa podem estar disponíveis aos agricultores, as quais não se referem apenas à rentabilidade de determinada tecnologia, mas também ao risco a que o agricultor estará se expondo na sua adoção (Porto et al., 1982).

Franke \& Dorfman (1998) afirmam que, para a quantificação do risco envolvido e do nível de manejo adequado para a otimização dos benefícios econômicos da irrigação, deve-se fazer um balanço hídrico diário no qual se verifique níveis de extração da capacidade de água disponível no solo e conseqüentemente, doses e turnos de irrigação mais viáveis. As diferentes frações de extração, traduzem necessidades de irrigação diferenciadas com seus respectivos níveis de probabilidade, que por sua vez, representam respostas e custos de irrigação diferenciados.

A caracterização de riscos climáticos tem sido feita para algumas culturas, tais como: arroz de sequeiro (Meireles et al., 1995; Silva et al., 1997), feijão (Meireles et al., 1997a, 1997b; Wrege et al., 1997; Silva et al., 1999), milho (Sans et al., 1997), soja (Farias et al., 1997), girassol (Marin et al., 2000; Rolim, 2000) e feijão-caupi (Andrade Júnior, 2000; Bastos et al., 2000), em vários Estados brasileiros, utilizando-se modelos de simulação.

Cardoso et al. (2004), verificaram um aumento nos riscos de estabelecimento do milho safrinha, para as condições edafoclimáticas de Londrina-PR, em função das

\footnotetext{
${ }^{1}$ FRIEDMAN, M.; SAVAGE, L.V. The utility analysis of choice involving risk. Journal of Political Economy, v. 56, n.4, p.279-304, 1948.
} 
deficiências hídricas impostas pela época de cultivo, detectando a inviabilidade do cultivo do milho em algumas épocas do ano.

Franke \& Dorfman (1998), em estudo de viabilidade econômica da irrigação na cultura do milho, verificaram que a atividade apresenta viabilidade econômica para diversas combinações de época de semeadura, nível de manejo da irrigação e nível de risco e à medida que o nível de risco aumentou, a irrigação em níveis menos intensos passou a apresentar viabilidade econômica. Verificaram, também, que a performance econômica da agricultura irrigada é inversamente proporcional ao comportamento das lâminas de irrigação suplementar necessárias; quanto maiores estas, menores são as receitas líquidas.

Andrade Júnior (2000), em análise da viabilidade econômica da irrigação das culturas do feijão-caupi e melancia, sob risco climático e econômico, em dois locais no estado do Piauí, também constatou que, as receitas líquidas oriundas do cultivo irrigado dessas culturas foram maiores à medida que o produtor se dispõe a correr um risco maior. Estudos deste tipo são ferramentas de grande potencial na análise probabilística da influência dos riscos climáticos sobre a rentabilidade das culturas e podem ser, também, integrados a um sistema de informação geográfica para espacialização de seus resultados, tornando possível uma análise econômica em nível regional.

Meireles (2000), trabalhando com o feijoeiro na região de Santo Antônio de Goiás-GO, visando a determinação das épocas de semeadura com menores riscos para a cultura, em condições de sequeiro e irrigado, utilizando as produtividades potencial e real, e a quebra relativa de produtividade simulada pelo modelo CROPGRO-Dry Bean, espacializou os resultados e verificou que para alguns locais e algumas épocas de semeadura, a utilização da irrigação suplementar é imprescindível, pois os riscos de quebra de rendimento de grãos, em função do déficit hídrico, chegaram a 95\%. 


\subsection{Espacialização de parâmetros agroclimáticos e econômicos}

De acordo com Oliveira (1990), em diversas localidades brasileiras vários estudos têm sido realizados visando verificar localmente a probabilidade de atendimento da demanda hídrica das culturas e sua viabilidade econômica a partir de dados climatológicos, principalmente pela análise da distribuição das chuvas e pelo método do balanço hídrico. Contudo, estas informações, pelo seu caráter local, são de utilização limitada. Desta forma, a espacialização das informações para uma determinada região tem uma enorme importância por disponibilizar informações regionais, possibilitando melhores estratégias de planejamento.

De acordo com Assad et al. (1998), as datas de plantio das diversas culturas em uma determinada região podem ser otimizadas, sendo isto realizado a partir da simulação dos termos de um balanço hídrico, cujos resultados quando georeferenciados, podem ser espacializados por meio de um Sistema de Informações Geográficas (SIG).

Existem diferentes métodos disponíveis nos SIG's para a espacialização de um atributo, quando o objetivo é mapear a sua variabilidade espacial. Entretanto, nem todos os modelos inferenciais propostos, respondem a questões básicas relacionadas à forma, tamanho e orientação do domínio a ser considerado na interpolação, não fornecendo, também, informações a respeito da incerteza associada aos valores estimados (Burrough \& McDonnel, 1998).

Quando uma certa variável apresenta continuidade espacial, comprovada pelo semivariograma experimental, deve-se utilizar técnicas especiais para a estimativa dos seus valores em locais não amostrados. A krigagem é o interpolador utilizado nos estudos geoestatísticos por ser não tendencioso e de variância mínima, assegurando a melhor estimativa. Dentre os tipos de krigagem existentes, a krigagem ordinária, de acordo com Felgueiras (2000), é um estimador que utiliza as médias locais ou tendências locais estimadas a partir das amostras vizinhas, ao invés de uma única média estacionária, como o faz um algoritmo de krigagem simples. Com o conhecimento do padrão de variabilidade espacial de um atributo, os seus valores em cada posição "s", não amostrada, são estimados sem a necessidade de se conhecer a média estacionária, 
segundo uma combinação linear dos valores de um subconjunto amostral local. A condição para isso é que o somatório dos ponderadores da krigagem ordinária seja igual a um.

Utilizando-se uma grade regular de valores estimados através da krigagem, podese elaborar mapas que representam a distribuição da variável em uma determinada região, os quais, constituem uma das maneiras mais ilustrativas para representar a espacialização ou regionalização de uma variável.

Vários trabalhos têm sido desenvolvidos visando a regionalização de informações utilizando técnicas geoestatísticas, principalmente para o estudo de parâmetros relacionados à ciência dos solos, fatores agroclimáticos, como evapotranspiração, chuva, temperatura, etc, e riscos envolvidos na produção de diversas culturas.

Heinemann \& Hoogenboom (2001), determinaram a necessidade de irrigação para a cultura do feijoeiro no nordeste da Bacia do Rio Tibagi, no estado do Paraná, utilizando o CROPGRO-Dry Bean associado a um sistema de informações geográficas para regionalizar as informações.

Sousa et al. (1999), trabalhando em um solo Aluvial na microbacia do Rio da Cruz, estado da Paraíba, mapearam a água disponível no solo (AD) em uma área de um hectare, representando-a por meio de mapas de isolinhas de valores de AD. Através da visualização da sua variabilidade espacial, dividiram a área em estudo em quatro classes de água disponível, permitindo o planejamento do manejo da irrigação conforme a $\mathrm{AD}$ em cada sub-área.

Faria et al. (2000), em um estudo de espacialização da demanda de irrigação suplementar para a cultura do milho no estado de Minas Gerais, para diferentes épocas de semeadura, considerando solos com três diferentes capacidades de retenção de água, constataram que a melhor época de semeadura para 85,6\% da área do Estado foi no período de setembro a outubro. Puderam também identificar, independentemente do tipo de solo, quatro regiões onde predominavam valores de demanda de irrigação suplementar real necessária para a cultura do milho superiores a $7 \mathrm{~mm} \mathrm{dia}^{-1}$, sendo estas localizadas nas áreas do médio Jequitinhonha, parte do Triângulo Mineiro, noroeste e extremo norte do Estado. 
Oliveira \& Carvalho (2003), realizaram um trabalho de regionalização das lâminas de irrigação suplementar e épocas de plantio do feijoeiro no estado de Goiás. Concluíram que com a regionalização das informações, as lâminas estimadas permitiram reduzir a quantidade de água aplicada, nos plantios de verão, safrinha e inverno, em $446,1 \% ; 235,7 \%$ e $66 \%$, respectivamente, gerando uma grande economia de água e energia para a região.

Gonçalves et al. (1998), trabalhando com o trigo no estado do Paraná, realizaram a regionalização das épocas de semeadura objetivando a redução dos riscos associados a fatores climáticos, e definiram épocas de semeadura com maiores probabilidades de se obter maiores rendimentos para nove zonas homogêneas no Estado. Constataram, que estes resultados, traziam sensíveis alterações nas épocas de semeadura anteriormente recomendadas, sendo estes resultados utilizados para as recomendações técnicas do cultivo do trigo e para normatizar a concessão de crédito aos agricultores.

Santana et al. (2003) desenvolveram um sistema de regionalização da demanda de irrigação suplementar para o estado de Minas Gerais denominado IRGNET, onde os dados poderiam ser disponibilizados na Internet. Avaliando o sistema, observaram que as maiores demandas de irrigação do feijoeiro, para duas épocas de semeadura, $1^{\circ}$ de maio e 15 de setembro, ocorreram nas regiões Norte, Vale do Rio Doce e Triângulo Mineiro. Quanto às classes de valores de lâminas necessárias durante o ciclo do feijoeiro, para a semeadura em $1^{\circ}$ de maio, a classe de $100 \mathrm{~mm}$ a $160 \mathrm{~mm}$ ocupou $35 \%$ da área do Estado, enquanto que para a semeadura em 15 de setembro, a classe de $120 \mathrm{~mm}$ a $160 \mathrm{~mm}$ ocupou $60,4 \%$ da área do Estado.

Visando delimitar áreas com menores riscos de ocorrência de déficit hídrico para a cultura do milho no Rio Grande do Sul em diversas datas de semeadura, utilizando um sistema de informações geográficas, Maluf et al. (2001) constataram que as regiões do Planalto, Alto e Médio Vales do Uruguai e Serra do Nordeste apresentaram as maiores disponibilidades hídricas do Estado. Analisando os mapas de risco de deficiência hídrica por período de semeadura, verificaram uma grande variação das áreas com menores riscos em função da época de semeadura, das condições de solo e do ciclo da cultura. 
Matzenauer et al. (1998), estudando o efeito da variabilidade das chuvas sobre a cultura da soja na região do Planalto Médio do Rio Grande do Sul, verificaram que a deficiência hídrica total no ciclo da cultura diminui à medida que se retarda a época de semeadura até dezembro. Verificaram, também, que os locais que apresentaram os maiores e menores valores médios de deficiência hídrica durante o ciclo da soja foram, respectivamente, Júlio de Castilhos e Passo Fundo.

Em estudo de zoneamento de riscos climáticos para o milho na região CentroOeste e estado de Minas Gerais, Sans et al. (2001) identificaram épocas de semeadura com menores riscos, sendo estes diretamente relacionados com a capacidade de água disponível no solo. Concluíram que a melhor época de semeadura para milho na safra de verão ocorre no mês de outubro e o atraso da semeadura implica em aumento dos riscos, sendo estes atribuídos à heterogeneidade de distribuição das chuvas aliada à variabilidade espacial dos solos.

Andrade Júnior et al. (2001) realizaram um zoneamento de risco climático para o cultivo de sequeiro do feijão-caupi no estado do Piauí, por meio da espacialização dos índices de satisfação das necessidades hídricas (relação entre a evapotranspiração real e evapotranspiração máxima), obtidos pela realização de balanços hídricos de cultivo simulando diversas datas de semeadura entre o período de 5 de novembro a 15 de janeiro e, em função dos tipos de solos existentes no Piauí, três níveis de CAD (30 mm, 45 mm e $55 \mathrm{~mm}$ ), sendo estes valores constantes ao longo do ciclo da cultura. Verificaram que, de uma forma geral, a região sudeste do Estado apresentou sempre os maiores riscos, independentemente da $\mathrm{CAD}$ e da data de semeadura, pois representa a região semi-árida do Estado, onde a ocorrência das chuvas é extremamente irregular e insuficiente para o suprimento hídrico da cultura. 


\section{MATERIAL E MÉTODOS}

\subsection{Local de estudo}

A área de abrangência do estudo foi o estado do Piauí, que apresenta uma área territorial de 251.529,182 $\mathrm{km}^{2}$ dividida em 222 municípios. O estado do Piauí apresenta três tipos climáticos, conforme a classificação de Köppen, sendo estes Aw, Aw' e BSh. O tipo Aw, quente e úmido com chuvas de verão, ocorre no centro-sul e sudoeste do Estado. A estação chuvosa ocorre de novembro a março, sendo dezembro, janeiro e fevereiro o trimestre mais chuvoso e junho, julho e agosto o mais seco, com as precipitações pluviométricas variando de $1.000 \mathrm{~mm}$ a $1.400 \mathrm{~mm}$ por ano. O tipo Aw', quente e úmido com chuvas de verão e outono, ocorre no norte do Estado, sendo que a estação chuvosa dessa região ocorre de janeiro a maio, sendo fevereiro, março e abril o trimestre mais chuvoso e agosto, setembro e outubro o mais seco, com média pluviométrica anual entre $1.000 \mathrm{~mm}$ e $1.800 \mathrm{~mm}$. O tipo BSh, semi-árido, ocorre no sudeste do Estado, sendo caracterizado por uma curta estação chuvosa no verão, entre os meses de dezembro e abril. As precipitações pluviométricas variam de $400 \mathrm{~mm}$ a 800 $\mathrm{mm}$ anuais, sendo janeiro, fevereiro e março o trimestre mais chuvoso e os meses de julho, agosto e setembro os mais secos e quentes do ano (Medeiros, 1996).

De acordo com os dados climatológicos do estado do Piauí, disponibilizados pelo Centro de Ciências Atmosféricas da Universidade Federal de Campina Grande, a média anual da umidade relativa do ar varia de 85\%, no centro-norte do Estado, a 55\%, no extremo sudeste, região semi-árida. A insolação, em alguns locais, ultrapassa 3.200 horas anuais e a temperatura média anual varia de $24,1^{\circ} \mathrm{C}$ a $27,8^{\circ} \mathrm{C}$. Os ventos são 
normalmente fracos ao longo do ano e, em geral, a velocidade média a $2 \mathrm{~m}$ de altura é inferior a $2 \mathrm{~m} \mathrm{~s}^{-1}$.

O estado do Piauí apresenta uma grande variabilidade de tipos de solo, destacando-se, em relação à área de abrangência, os Latossolos, Neossolos, Argissolos, Nitossolos e Luvissolos (Embrapa, 1999). De uma forma geral, apresentam de média a baixa fertilidade natural e grande variabilidade na capacidade de retenção de água, devido às diferentes composições granulométricas. No entanto, apresentam grande potencialidade agrícola devido às suas características físico-químicas e topográficas.

Em decorrência de sua posição geográfica, o estado do Piaúi apresenta uma típica zona de transição, possuindo, conjuntamente, aspectos do semi-árido nordestino, da pré-Amazônia e do Planalto Central do Brasil. Refletindo as condições de umidade das diversas zonas, as características da vegetação distribuem-se em faixas paralelas, com a caatinga arbórea e arbustiva predominando no sudeste, a floresta decidual no Baixo e Médio Parnaíba, cerrado e cerradão no centro-leste e sudoeste e as formações pioneiras de restinga, mangue e aluvial campestre, na zona litorânea. As formações vegetais são separadas por zonas de contato, nas quais ocorrem dois ou mais tipos de associações de plantas, constituindo agrupamentos de transição.

\subsection{Precipitação pluviométrica}

Utilizou-se neste estudo dados provenientes de registros diários de precipitação pluviométrica obtidos junto a postos pluviométricos da Superintendência de Desenvolvimento do Nordeste (SUDENE) e do Instituto Nacional de Meteorologia (INMET) instalados em 165 locais, sendo 145 localizados no estado do Piauí e os demais nos estados vizinhos do Maranhão, Bahia, Ceará e Pernambuco (Figura 1). Dos 165 postos pluviométricos apenas dois apresentam séries históricas de precipitação inferiores a 15 anos de dados, sendo que os demais apresentam entre 15 e 20 anos de registros diários de chuva. Os postos pluviométricos utilizados no estudo, bem como suas coordenadas geográficas e número de anos das séries históricas de dados, são apresentados no Apêndice 1. 


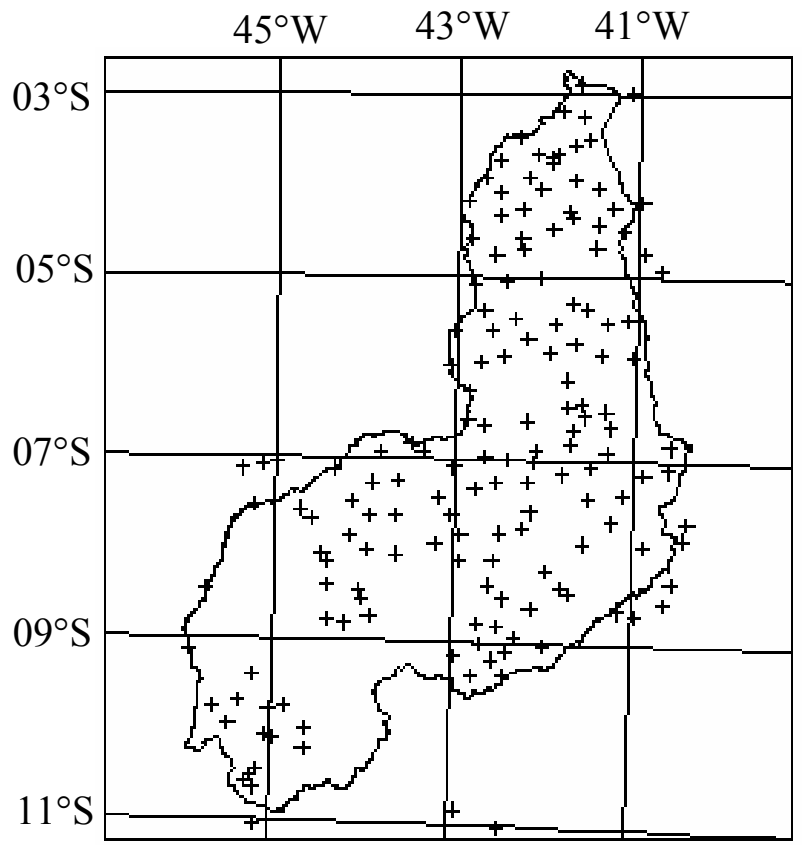

Figura 1 - Localização geográfica dos postos pluviométricos onde foram obtidos os dados diários de precipitação pluviométrica

\subsection{Evapotranspiração de referência}

A evapotranspiração de referência $\left(\mathrm{ET}_{0}\right)$, em escala diária, foi estimada para os mesmos 165 locais onde se dispunha dos dados pluviométricos, utilizando-se o método de Thornthwaite (1948). Por não se dispor de dados de temperatura média do ar para todos os locais, as mesmas foram estimadas utilizando-se as equações para a estimativa da média mensal de temperatura do ar para o estado do Piaú, propostas por Lima \& Ribeiro (1998), as quais se baseiam na latitude, longitude e altitude do local. A partir destas equações, foram obtidas, para cada mês do ano, as temperaturas médias do ar em cada um dos 165 locais, podendo-se assim estimar os valores mensais de $\mathrm{ET}_{0}$, sendo os valores diários obtidos para cada local dividindo-se os valores de $\mathrm{ET}_{0}$ mensal pelo número de dias do respectivo mês. 
Por não haver alterações expressivas nos valores diários de $\mathrm{ET}_{0}$ de um ano para $\mathrm{o}$ outro, para fins de execução dos balanços hídricos diários, os seus valores foram considerados iguais para todos os anos das séries históricas de precipitação pluviométrica.

\subsection{Datas de semeadura}

Foram utilizadas doze datas de semeadura diferentes, tendo como data padrão o primeiro dia de cada mês, tanto para a condição de sequeiro quanto para a condição de cultivo com a presença da irrigação.

\subsection{Parâmetros da cultura}

O feijão-caupi, em virtude das condições climáticas presentes no estado do Piauí, pode ser cultivado em qualquer época do ano, desde que haja suplementação hídrica, sendo que a duração do seu ciclo praticamente não varia ao longo do ano. Sendo assim, para fins de execução dos balanços hídricos diários, considerou-se o seu ciclo igual a 65 dias para todas as épocas de semeadura utilizadas. Este período de 65 dias vai da emergência das plântulas até a maturidade fisiológica dos grãos (Bezerra \& Freire Filho, 1984). Considerando-se que a emergência ocorre normalmente cinco dias após a semeadura, independentemente da época do ano, o ciclo total do feijoeiro, da semeadura à maturidade fisiológica, foi considerado igual a 70 dias para todos os locais e para todas as épocas de semeaduras utilizadas.

Os valores de coeficiente de cultivo $(\mathrm{Kc})$ utilizados para a estimativa da evapotranspiração máxima da cultura (ETm), nos seus diferentes estádios de desenvolvimento, foram obtidos a partir de trabalhos de pesquisa conduzidos em condições edafoclimáticas semelhantes (Bezerra \& Freire Filho, 1984; Saunders et al., 1985; Lima \& Silva, 1988; Andrade et al., 1993; Barros et al., 1998; Bezerra \& Oliveira, 1998; Santos et al., 1998; Bezerra et al., 1999), tendo como orientação os valores recomendados por Doorenbos \& Kassam (2000). 
As fases de desenvolvimento da cultura foram definidas de acordo com a recomendação de Doorenbos \& Kassam (2000) e por pesquisas locais, sendo: I - estabelecimento (da emergência até 10\% de cobertura do solo); II - desenvolvimento vegetativo (de 10\% de cobertura do solo ao início da floração); III - floração e frutificação (do início da floração até o início da maturação) e IV - maturação (início da maturação à colheita). Os valores de Kc utilizados para cada fase de desenvolvimento da cultura e a duração das respectivas fases são apresentados na Tabela 1.

Tabela 1. Coeficientes de cultivo (Kc) para cada fase de desenvolvimento do feijãocaupi

\begin{tabular}{ccc}
\hline Fase & Dias após semeadura (DAS) & Kc \\
\hline I & $0-20$ & 0,40 \\
II & $21-45$ & 0,80 \\
III & $46-60$ & 1,20 \\
IV & $61-70$ & 0,70 \\
\hline
\end{tabular}

Utilizou-se o valor da profundidade efetiva do sistema radicular do feijão-caupi igual a 0,25 m (Nogueira \& Nogueira, 1995), considerado constante durante o ciclo da cultura para fins da obtenção das diferentes CAD's.

\subsection{Parâmetros do solo}

Face à grande variabilidade de tipos de solos presentes no estado do Piauí e, conseqüentemente, das suas diferentes capacidades de retenção de água, os balanços hídricos foram executados para situações que fossem representativas da capacidade de retenção da maioria dos solos presentes no Estado.

A capacidade de água disponível no solo (CAD) pode ser definida como o armazenamento máximo de água no solo, disponível para as plantas, sendo calculada pela expressão:

$$
\mathrm{CAD}=\left(\theta_{\mathrm{CC}}-\theta_{\mathrm{PMP}}\right) \mathrm{Z}
$$


em que:

CAD - capacidade de água disponível no solo, L;

$\theta_{\mathrm{CC}}$ - umidade do solo na capacidade de campo, $\mathrm{L}^{3} \mathrm{~L}^{-3}$;

$\theta_{\mathrm{PMP}}$ - umidade do solo no ponto de murcha permanente, $\mathrm{L}^{3} \mathrm{~L}^{-3}$;

$\mathrm{Zi}$ - profundidade efetiva do sistema radicular, $\mathrm{L}$.

Embora haja uma variação da CAD ao longo do ciclo das culturas, por causa do crescimento do sistema radicular até atingir a profundidade efetiva e das características físicas do solo nas diferentes profundidades, para as condições deste trabalho, os valores de CAD foram considerados constantes ao longo do ciclo da cultura. Foram utilizados três valores de CAD para a realização dos balanços hídricos: $20 \mathrm{~mm}, 40 \mathrm{~mm}$ e $60 \mathrm{~mm}$, representando, respectivamente, os solos com menor capacidade de retenção de água, os solos de média capacidade e os solos de alta capacidade de retenção de água, sendo esses valores representativos dos diferentes tipos de solos existentes no estado do Piauí, de acordo com informações de $\mathrm{Melo}^{2}$.

\subsection{Balanço hídrico}

Os balanços hídricos de cultivo (BHC), em escala diária, foram realizados durante o ciclo do feijão-caupi, considerando-se o seu cultivo irrigado e de sequeiro, utilizando-se a metodologia proposta por Thornthwaite \& Mather (1955) e descrita por Pereira et al. (2002), sendo os mesmos executados para cada ano da série histórica de dados pluviométricos, para cada um dos 165 locais estudados, em cada uma das doze datas de semeadura e para os três valores de CAD. Para tal foi desenvolvida uma rotina computacional na linguagem de programação Visual Basic 6.0 (macros) vinculada à planilha eletrônica Excel 2000 (Microsoft), sendo incluída nesta, a opção para a realização de simulação utilizando o método de Monte Carlo.

\footnotetext{
${ }^{2}$ MELO, F. de B. Comunicação pessoal, 2000.
} 
Como nem toda a precipitação ocorrida em um determinado local torna-se disponível às plantas, para fins da sua utilização nos $\mathrm{BHC}$, estimou-se a precipitação efetiva diária através de uma percentagem fixa das precipitações totais diárias. O método da percentagem fixa é definido como a precipitação efetiva com uma probabilidade de excedência respectiva à percentagem aplicada, conforme descrevem Sampaio et al. (2000). Para as condições do presente estudo, foi utilizada a percentagem de 75\%, de acordo com as recomendação de Silva et al. (1988), Bernardo (1989) e Doorenbos e Pruitt (1997), utilizando a CAD como valor limite da precipitação efetiva, conforme adaptação proposta pela Embrapa (2003b), sendo:

$$
\begin{aligned}
& \operatorname{Pef}_{\mathrm{i}}=\mathrm{Pt}_{\mathrm{i}} \quad \text { se } \quad \mathrm{Pt}_{\mathrm{i}} \leq \mathrm{CAD} \\
& \mathrm{Pef}_{\mathrm{i}}=0,75 \mathrm{Pt}_{\mathrm{i}} \text { se } \mathrm{Pt}_{\mathrm{i}}>\mathrm{CAD}
\end{aligned}
$$

em que:

$$
\begin{aligned}
& \mathrm{Pef}_{\mathrm{i}} \text { - precipitação efetiva ocorrida no dia i, L; } \\
& \mathrm{Pt}_{\mathrm{i}} \text { - precipitação total ocorrida no dia i, L; }
\end{aligned}
$$

$\mathrm{Na}$ realização dos balanços hídricos para a cultura irrigada, considerou-se uma dotação de rega variável, utilizando uma lâmina de irrigação visando sempre elevar o armazenamento de água no solo à capacidade de campo antes que as plantas apresentem sinal da falta de água. Desta forma, a irrigação deve ser realizada antes das plantas atingirem este ponto. Conforme citam Pereira et al. (2002), este ponto representa um percentual da CAD denominado Água Facilmente Disponível (AFD), isto é, aquele que pode ser extraído do solo a partir do armazenamento máximo, sem que ocorra déficit hídrico à cultura, expressa por:

$$
\mathrm{AFD}=\mathrm{f} \mathrm{CAD}
$$

em que:

AFD - água facilmente disponível, L; 
$\mathrm{f}$ - fração de esgotamento da água no solo, adimensional.

Desta forma, na realização do balanço hídrico da cultura irrigada, realizou-se a irrigação quando foi consumida a água facilmente disponível.

A fração f, varia com o tipo da cultura e das suas necessidades hídricas em cada estágio de desenvolvimento, sendo, portanto, variável durante o ciclo da cultura. Entretanto, para fins práticos, adota-se valores fixos. Para as condições do presente estudo, utilizou-se o valor de f igual a 0,5 , de acordo com recomendações de Doorenbos \& Kassam (2000).

Na condição da cultura irrigada, para fins de estimativa da lâmina bruta de irrigação, considerou-se que a irrigação seria feita por aspersão convencional, sendo a eficiência do sistema pré-fixada em $75 \%$. Utilizou-se este valor de eficiência por ser um valor que, em nível de propriedade rural, pode ser perfeitamente obtido com o manejo adequado do sistema.

Os BHC's foram então realizados para cada local, combinando-se as doze datas de semeadura e três CAD's no solo, para as condições de sequeiro e irrigado. Os BHC's sob condição de sequeiro foram realizados de forma a se verificar a viabilidade econômica da implementação do cultivo irrigado do feijão-caupi.

Como resultado dos balanços hídricos diários durante o ciclo do feijão-caupi em cada local, foram obtidos, para as diversas combinações de data de semeadura e CAD, a evapotranspiração máxima da cultura (ETm) e a evapotranspiração real da cultura (ETr), para a condição de sequeiro, e valores de ETm e ETr, bem como valores de lâmina bruta de irrigação necessária, para a condição da cultura irrigada, sendo que para esta condição, por não haver déficit hídrico no solo, o valor de ETr foi igual a ETm. Os resultados dos balanços hídricos foram utilizados em etapa posterior para a estimativa do rendimento relativo e receita líquida proveniente do cultivo do feijão-caupi.

\subsection{Rendimento relativo do feijão-caupi}


A ocorrência de déficits hídricos pode se dar, tanto durante todo o ciclo da cultura, como também em uma ou mais fases do seu desenvolvimento. Para a cultura do feijão-caupi, alguns trabalhos comprovaram que a cultura, em termos de rendimento, reage diferentemente ao déficit hídrico em função da fase de desenvolvimento. Desta forma, o déficit hídrico ocorrido em uma ou mais fases está associado a uma redução percentual na produtividade máxima, sendo o rendimento relativo dado pela relação entre este rendimento máximo e o déficit de evapotranspiração em cada fase de desenvolvimento.

Quando existe uma dependência entre os efeitos dos déficits hídricos ocorridos em diferentes estádios fenológicos de uma cultura, a estimativa do seu rendimento relativo é melhor obtida pela utilização de um modelo multiplicativo entre o rendimento potencial e o déficit de evapotranspiração (Frizzone, 1998). Um dos modelos multiplicativos foi proposto por Rao et al. (1988) e é apresentado por Frizzone (2005), sendo dado por:

$$
\mathrm{Yr}=\mathrm{Ym}\left\{\prod_{\mathrm{i}=1}^{4}\left[1-\mathrm{Ky}_{\mathrm{i}}\left(1-\frac{\mathrm{ETr}_{\mathrm{i}}}{\mathrm{ETm}_{\mathrm{i}}}\right)\right]\right\}
$$

em que:

$\mathrm{Yr}$ - produtividade real da cultura, $\mathrm{kg} \mathrm{ha}^{-1}$;

Ym - produtividade máxima ou potencial da cultura, $\mathrm{kg} \mathrm{ha}^{-1}$;

$\mathrm{Ky}_{\mathrm{i}}$ - fator de resposta da cultura ao déficit hídrico na fase i, adimensional;

$\mathrm{ETr}_{\mathrm{i}}$ - evapotranspiração real da cultura na fase $\mathrm{i}, \mathrm{mm}$;

$\mathrm{ETm}_{\mathrm{i}}$ - evapotranspiração máxima da cultura na fase i, mm.

Embora os valores de Ky para a maioria das culturas tenham sido determinados supondo-se que a relação entre o rendimento relativo e a evapotranspiração relativa $(\mathrm{ETr} / \mathrm{ETm})$ seja linear e válida apenas para déficits hídricos de até $50 \%$, ou seja, $(1-\mathrm{ETr} / \mathrm{ETm})=0,5$, e como não se conhecia, a priori, o grau de déficit sofrido pela cultura nas diversas situações simuladas, utilizou-se os mesmos valores de Ky para todas as condições de déficit hídrico. 
Os valores de $\mathrm{Ky}$, para cada fase da cultura, utilizados para as estimativas do rendimento relativo, são apresentados na Tabela 2. Os mesmos foram definidos com base em Doorenbos \& Kassam (2000) e em trabalhos realizados em condições edafoclimáticas semelhantes conduzidos por Cordeiro et al. (1998).

Tabela 2. Fator de resposta ao déficit hídrico $(\mathrm{Ky})$ para cada fase de desenvolvimento do feijão-caupi

\begin{tabular}{ccc}
\hline Fase & Dias após semeadura (DAS) & Ky \\
\hline I & $0-20$ & 0,20 \\
II & $21-45$ & 0,35 \\
III & $46-60$ & 1,10 \\
IV & $61-70$ & 0,20 \\
\hline
\end{tabular}

Segundo Doorenbos \& Kassam (2000), o rendimento potencial ou máximo de uma cultura (Ym) é aquele obtido pelo cultivo de uma variedade altamente produtiva e adaptada, em condições ótimas de suprimento dos fatores de produção e sem limitação de qualquer fator que possa comprometer seu pleno desenvolvimento, como pragas, doenças e ervas daninhas. Face à grande dificuldade da ocorrência destas condições em nível de campo, uma estimativa aproximada do rendimento potencial pode ser obtida a partir de valores potenciais de produtividade, em nível de campo ou experimentais, obtidos nas condições edafoclimáticas de interesse.

Considerando os resultados de pesquisa locais e informações de produtores, para as condições deste estudo assumiu-se como rendimento potencial da cultura do feijãocaupi para o estado do Piauí o valor de $2.500 \mathrm{~kg} \mathrm{ha}^{-1}$. Para garantir uma maior margem de segurança dos resultados, este valor representa cerca de $80 \%$ dos níveis de rendimento obtidos em experimentos conduzidos no Estado por Cardoso et al. (1987), Cardoso et al. (1991) e Cardoso et al. (1997).

Embora os balanços hídricos tenham fornecido valores diários de ETr e ETm, os valores utilizados na eq. (5) foram valores médios de cada fase de desenvolvimento da 
cultura. Desta forma, foram obtidas séries de valores de rendimento relativo com igual número de anos das séries de dados pluviométricos, para cada um dos 165 locais e para todas as combinações de data de semeadura e CAD.

\subsection{Simulação do rendimento relativo e lâmina bruta}

Como etapa anterior à simulação, realizou-se o teste de aderência de Kolmogorov-Smirvov, ao nível de significância de 5\%, para as séries de rendimento relativo e lâmina bruta obtidos nos BHC's. Sendo confirmado o ajuste dos dados à distribuição de probabilidade normal e utilizando-se os parâmetros desta distribuição, média e desvio padrão, procedeu-se a realização de mil simulações utilizando o método de Monte Carlo, o que resultou para cada local analisado a obtenção de mil valores de rendimento relativo, para cada uma das combinações de datas de semeadura e CAD, para o cultivo de sequeiro; mil valores de rendimento relativo e mil valores de lâmina bruta para as combinações de datas de semeadura e CAD, para o cultivo sob irrigação.

O processo de simulação pelo método de Monte Carlo, considerando o ajuste dos dados à distribuição normal, foi realizado utilizando-se a expressão apresentada por Frizzone \& Silveira (2000) aplicada à distribuição normal:

$$
\mathrm{RSi}=\frac{\sigma}{\sqrt{\frac{\mathrm{m}}{12}}} \sum_{\mathrm{i}=1}^{\mathrm{m}} \mathrm{r}_{\mathrm{i}}+\left(\mu-\frac{\mathrm{m}}{2} \frac{\sigma}{\sqrt{\frac{\mathrm{m}}{12}}}\right)
$$

em que:

$\mathrm{RSi}$ - rendimento relativo simulado;

$\sigma$ - desvio padrão da amostra;

$\mathrm{m}$ - quantidade de número aleatórios gerados;

$\mu$ - média da amostra; 
$\mathrm{r}_{\mathrm{i}}-$ número aleatório gerado.

Com vistas a eliminar os termos da raiz quadrada da eq. (6), optou-se pela utilização de doze números aleatórios para a simulação de cada valor (RSi). Com isso, a eq. (6) ficou simplificada em:

$$
\mathrm{RSi}=\sigma \sum_{\mathrm{i}=1}^{\mathrm{m}} \mathrm{r}_{\mathrm{i}}+(\mu-6 \sigma)
$$

\subsection{Análise econômica sob condição de risco}

$\mathrm{Na}$ análise econômica, considerou-se apenas o risco climático, ocasionado pela variabilidade das precipitações, sendo este inserido em virtude das estimativas probabilísticas de valores de lâmina bruta e rendimento relativo para a cultura irrigada e de valores de rendimento relativo para a cultura de sequeiro.

Os níveis de risco utilizados foram $25 \%, 50 \%$ e $75 \%$, constituindo, portanto, o complemento percentual para se atingir a condição de certeza em relação aos valores de probabilidade de ocorrência $75 \%, 50 \%$ e $25 \%$, respectivamente.

A partir dos mil valores de rendimentos relativos e lâminas brutas obtidos pela simulação e utilizando-se a função inversa da distribuição normal, foram estimados valores de rendimento relativo e lâmina bruta, quando foi o caso, com probabilidade de ocorrência de $75 \%, 50 \%$ e $25 \%$, ou seja, com níveis de risco $25 \%$, 50\% e $75 \%$, respectivamente.

Para fins de análise, tendo em vista a atual situação de gestão dos recursos hídricos no Piauí e que a quase totalidade das propriedades rurais do Estado enquadramse na classe rural de consumo, na qual não incide a cobrança de tarifa de demanda nem as tarifas horo-sazonais, o custo da água foi estimado pelo custo da energia elétrica consumida por um sistema de irrigação por aspersão convencional capaz de aplicar a lâmina requerida pela cultura durante o seu ciclo. Desta forma, o custo da energia elétrica foi estimado pela equação adaptada de Frizzone (2005): 


$$
\mathrm{CE}_{\mathrm{ijkr}}=\frac{10 \mathrm{I}_{\mathrm{ijkr}} \operatorname{Hm} \gamma_{\mathrm{a}}}{3,610^{6} \eta} \mathrm{Tc}
$$

em que:

$\mathrm{CE}_{\mathrm{ijkr}}$ - custo de energia elétrica, durante o ciclo do feijão-caupi no local i, época de semeadura j, capacidade água disponível $\mathrm{k}$, risco $\mathrm{r}, \mathrm{US} \$ \mathrm{ha}^{-1}$;

$\mathrm{I}_{\mathrm{ijkr}}$ - lâmina bruta de irrigação necessária durante o ciclo do feijão-caupi no local i, na época de semeadura j, capacidade água disponível $\mathrm{k}$ e risco r, mm;

$\mathrm{Hm}$ - altura manométrica total, $60 \mathrm{~m}$;

$\gamma_{\mathrm{a}}$ - peso específico da água, $9.806,65 \mathrm{~N} \mathrm{~m}^{-3}$;

$\eta$ - eficiência global do conjunto eletrobomba, 0,65 ;

Tc - tarifa de consumo de energia elétrica referente ao período do ciclo do feijão-caupi, 0,08523 US\$ $\mathrm{kWh}^{-1}$.

Para a estimativa do custo da energia elétrica (CE), o valor da tarifa utilizado representa a tarifa de consumo obtida junto à Companhia Energética do Piauí no mês de fevereiro de $2005\left(0,221587 \mathrm{R} \$ \mathrm{kWh}^{-1}\right)$, e convertido em dólar à taxa de câmbio $\mathrm{R} \$ 2,60 \mathrm{US \$}^{-1}$, representando o valor cobrado para o consumidor rural, sem os subsídios da Lei Estadual de incentivo à irrigação. O valor da altura manométrica utilizada $(60 \mathrm{~m})$, representa uma situação hipotética representativa da maioria dos sistemas de irrigação por aspersão convencional instalados no estado do Piauí, sendo este obtido junto a empresas de elaboração de projetos e consultoria de irrigação que atuam no Estado e à Embrapa Meio-Norte.

O custo de implantação da cultura ou custo de produção (CP) utilizado para as análises, exceto o custo da água, foi de US\$ 322,91 ha ${ }^{-1}$. Este custo é um valor médio representativo das condições de mercado do Piauí para um nível de tecnologia compatível com a utilização da irrigação. No referido custo não foram incluídos os 
custos de mão-de-obra, comercialização, seguros e manutenção, pois estes, geralmente, representam um pequeno percentual do custo total.

O custo fixo anualizado $(\mathrm{CF})$ referente à amortização do sistema de irrigação por aspersão convencional foi de US\$283,17 ha ${ }^{-1}$, sendo este estimado por meio do fator de recuperação de capital:

$$
\mathrm{CF}=\mathrm{C} \text { FRC }
$$

sendo:

$$
F R C=\left[\frac{(1+j)^{n} j}{(1+j)^{n}-1}\right]
$$

em que:

CF - custo fixo anual de amortização do equipamento de irrigação;

C - custo de aquisição de um sistema de irrigação por aspersão convencional, 1600,00 US\$ ha ${ }^{-1}$;

FRC - Fator de recuperação do capital;

$\mathrm{j}$ - taxa anual de juros, 0,12 ;

$\mathrm{n}$ - vida útil do sistema de irrigação, 10 anos.

Os custos totais de produção da cultura foram dados por:

$$
\begin{array}{ll}
\mathrm{CTI}_{\mathrm{ijkr}}=\mathrm{CP}+\mathrm{CE}_{\mathrm{ijkr}}+\mathrm{CF} & \text { (cultura irrigada) } \\
\mathrm{CTS}_{\mathrm{ijkr}}=\mathrm{CP} & \text { (sequeiro) }
\end{array}
$$

em que:

$\mathrm{CTI}_{\mathrm{ijkr}}$ - custo total de produção do feijão-caupi irrigado, no local i, época de semeadura j, capacidade água disponível k e risco r, US\$ ha ${ }^{-1}$; 
$\mathrm{CTS}_{\mathrm{ijkr}}$ - custo total de produção do feijão-caupi de sequeiro, no local i, época de semeadura $\mathrm{j}$, capacidade água disponível $\mathrm{k}$ e risco $\mathrm{r}$, US\$ ha ${ }^{-1}$;

$\mathrm{CP}$ - custo de implantação da cultura, US\$ 322,91 ha ${ }^{-1}$;

$\mathrm{CE}_{\mathrm{ijkr}}$ - custo de energia elétrica, durante o ciclo do feijão-caupi no local i, época de semeadura $\mathrm{j}$, capacidade água disponível $\mathrm{k}$ e risco $\mathrm{r}, \mathrm{US} \$ \mathrm{ha}^{-1}$;

CF - custo fixo anual de amortização do sistema de irrigação, US\$ 283,17 ha ${ }^{-1}$.

O preço de venda do feijão-caupi utilizado para a realização do estudo foi de US\$ $0,46 \mathrm{~kg}^{-1}$, sendo este em nível de produtor rural e refere-se ao preço médio obtido junto à CEASA-PI, convertido em dólar de acordo com a cotação do câmbio em fevereiro de 2005, quando US\$1,00 $=\mathrm{R} \$ 2,60$.

As receitas líquidas (RL) esperadas com o cultivo do feijão-caupi irrigado e de sequeiro, em cada local e para cada condição simulada, com determinado nível de risco, foram estimadas a partir dos rendimentos relativos e das lâminas brutas obtidos para cada situação utilizando as expressões:

$$
\begin{array}{ll}
\mathrm{RLI}_{\mathrm{ijkr}}=\mathrm{RBI}_{\mathrm{ijkr}}-\mathrm{CTI}_{\mathrm{ijkr}} & \text { (cultura irrigada) } \\
\mathrm{RLS}_{\mathrm{ijkr}}=\mathrm{RBS}_{\mathrm{ijkr}}-\mathrm{CTS}_{\mathrm{ijkr}} & \text { (sequeiro) }
\end{array}
$$

sendo:

$$
\begin{array}{ll}
\mathrm{RBI}_{\mathrm{ijkr}}=\mathrm{YIr}_{\mathrm{ijkr}} \text { Pf } & \text { (cultura irrigada) } \\
\mathrm{RBS}_{\mathrm{ijkr}}=\mathrm{YSr}_{\mathrm{ijkr}} \text { Pf } & \text { (sequeiro) }
\end{array}
$$

em que:

$\mathrm{RLI}_{\mathrm{ijkr}}$ - receita líquida obtida pelo cultivo irrigado do feijão-caupi no local $\mathrm{i}$, época de semeadura $\mathrm{j}$, capacidade água disponível $\mathrm{k}$, risco $\mathrm{r}$, US\$ ha ${ }^{-1}$; 
$\mathrm{RLS}_{\mathrm{ijkr}}$ - receita líquida obtida pelo cultivo de sequeiro do feijão-caupi no local $\mathrm{i}$, época de semeadura j, capacidade água disponível $\mathrm{k}$, risco $\mathrm{r}$, US\$ ha ${ }^{-1}$;

$\mathrm{RBI}_{\mathrm{ijkr}}$ - receita bruta obtida pelo cultivo irrigado do feijão-caupi no local $\mathrm{i}$, época de semeadura $\mathrm{j}$, capacidade água disponível $\mathrm{k}$, risco $\mathrm{r}, \mathrm{US} \$ \mathrm{ha}^{-1}$;

$\mathrm{RBS}_{\mathrm{ijkr}}$ - receita bruta obtida pelo cultivo de sequeiro do feijão-caupi no local $\mathrm{i}$, época de semeadura $\mathrm{j}$, capacidade água disponível $\mathrm{k}$, risco $\mathrm{r}$, US\$ ha ${ }^{-1}$;

$\mathrm{CTI}_{\mathrm{ijkr}}$ - custo total de produção do feijão-caupi irrigado, no local i, época de

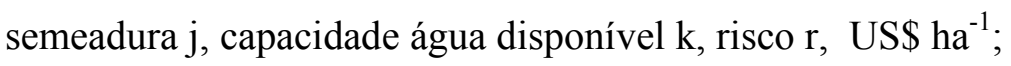

$\mathrm{CTS}_{\mathrm{ijkr}}$ - custo total de produção do feijão-caupi de sequeiro, no local i, época de

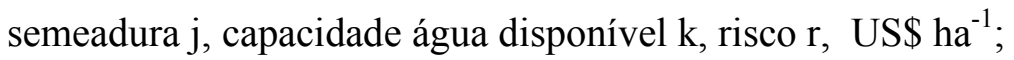

$\mathrm{YIr}_{\mathrm{ijkr}}$ - rendimento real do feijão-caupi irrigado, no local i, época de semeadura $\mathrm{j}$, capacidade água disponível $\mathrm{k}$, risco $\mathrm{r}, \mathrm{US}_{\mathrm{N}} \mathrm{ha}^{-1}$;

$\mathrm{YSr}_{\mathrm{ijkr}}$ - rendimento real do feijão-caupi cultivado em sequeiro, no local i, época de semeadura j, capacidade água disponível $\mathrm{k}$, risco $\mathrm{r}$, US\$ ha ${ }^{-1}$;

Pf - preço médio de venda do feijão-caupi, 0,46 US\$ $\mathrm{kg}^{-1}$.

\subsection{Espacialização das receitas líquidas}

De acordo com Gonçalves (1997), a realização de qualquer estudo estatístico ou geoestatístico assume a condição de normalidade dos dados, embora esta hipótese geralmente não seja testada. Segundo Hamlett et al. (1986), a análise exploratória dos valores de uma determinada variável, distribuída no espaço, é um procedimento indispensável em estudos geoestatísticos, pois por intermédio deste se verifica o seu ajuste à distribuição normal. Gonçalves et al. (2001) também ressaltaram a importância de uma cuidadosa análise de variáveis espacialmente distribuídas como etapa prévia de uma análise geoestatística.

Desta forma, como etapa inicial para a espacialização das receitas líquidas obtidas dos cultivos irrigado e de sequeiro do feijão-caupi para o estado do Piauí, sob risco de $25 \%, 50 \%$ e $75 \%$, e elaboração dos respectivos mapas temáticos, para todas as combinações de época de semeadura e $\mathrm{CAD}$, foram realizadas as análises exploratórias 
dos respectivos dados obtidos nos 165 locais, com vistas a verificar o ajuste dos mesmos à distribuição normal.

Confirmada a hipótese de normalidade dos dados, considerando que para a realização de estudos geoestatísticos o ajuste dos mesmos a esta distribuição pode ser apenas aproximado (Warrick \& Nielsen ${ }^{3}$, citados por Gonçalves et al., 2001), foram gerados os semivariogramas experimentais utilizando o software GS+ - geostatistics for the environmental sciences (Robertson, 1998), por meio do estimador apresentado por Journel (1989):

$$
\hat{\gamma}(h)=\frac{1}{2 N(h)} \sum_{1}^{N(h)}[Z(s)-Z(s+h)]^{2}
$$

em que:

$\hat{\gamma}(\mathrm{h})$ - semivariância;

$\mathrm{Z}(\mathrm{s})$ - valor da variável na posição "s";

$\mathrm{Z}(\mathrm{s}+\mathrm{h})$ - valor da variável em uma posição "s+h";

$\mathrm{N}(\mathrm{h})$ - número de pares de dados separados por uma distância "h".

Após a geração dos semivariogramas experimentais, foi realizado o ajuste dos mesmos a um modelo matemático teórico. A partir da análise dos modelos de semivariogramas ajustados, bem como dos seus coeficientes: efeito pepita, alcance e patamar, foi realizado o estudo da variabilidade espacial das receitas líquidas obtidas do cultivo do feijão-caupi no estado do Piauí considerando as diversas situações de cultivo e risco impostas à cultura.

Confirmada a continuidade espacial dos valores de receitas líquidas oriundas do cultivo do caupi nas diversas situações, os mesmos foram estimados para cada posição

\footnotetext{
${ }^{3}$ WARRICK, A.W.; NIELSEN, D.R. Spatial variability of soil physical properties on the field. In: HILLEL, D. (Ed.). Applications of soil physics. New York: Academic Press, 1980. p.319-344.
} 
(s), não amostrada, por meio da "krigagem" ordinária, utilizando-se o software Spring 4.1 (Câmara et al., 1996).

O estimador da krigagem ordinária é dado por:

$$
\mathrm{Z}_{\mathrm{Xo}}^{*}=\sum_{\mathrm{i}=1}^{\mathrm{n}} \lambda_{\mathrm{i}} \mathrm{Z}_{\mathrm{Xi}}
$$

sendo:

$$
\sum_{i=1}^{n} \lambda_{i}=1
$$

em que:

$Z^{*} \mathrm{Xo}_{0}$-valor estimado da variável no local Xo;

$Z^{*}{ }_{X i}$ - valor da variável na posição vizinha $i$, conhecida;

$\lambda \mathrm{i}$ - fator de ponderação.

A partir da grade resultante da interpolação por "krigagem" ordinária, os valores de receita líquida foram espacializados para o estado do Piauí, utilizando-se o software Spring 4.1 (Câmara et al. 1996). Realizou-se o fatiamento em nove classes temáticas de receitas líquidas, obtendo-se, assim, os mapas temáticos de receitas líquidas dos cultivos irrigado e de sequeiro do feijão-caupi, para cada combinação de data de semeadura, CAD e risco, recortando-se o plano de informação para os limites do Estado. 


\section{RESULTADOS E DISCUSSÃO}

\subsection{CAD e viabilidade econômica da irrigação do feijão-caupi no estado do Piaú́}

Os mapas temáticos de receitas líquidas simuladas auferidas pelo cultivo do feijão-caupi no estado do Piauí, para as diversas combinações de $\mathrm{CAD}$, risco climático e data de semeadura, são apresentados nas Figuras 3 a 14 - Anexo A, para a situação do cultivo irrigado, e Figuras 15 a 26, Anexo B, para a situação do cultivo de sequeiro. Para o cultivo irrigado, observa-se que, independentemente da época de semeadura e do nível de risco adotado, as receitas líquidas aumentaram com o crescimento da CAD de $20 \mathrm{~mm}$ para $60 \mathrm{~mm}$, pois quanto maior a CAD menores foram as lâminas de irrigação a serem aplicadas e vice-versa. Com o aumento das lâminas de irrigação, maiores foram os custos referentes à aplicação de água, que neste caso, representaram o custo com energia elétrica para o bombeamento, aumentando o custo total de produção e diminuindo, assim, as receitas líquidas. Este resultado está de acordo com os obtidos por Franke \& Dorfman (1998), que concluíram que o desempenho econômico da agricultura irrigada é inversamente proporcional ao comportamento das lâminas de irrigação necessárias; quanto maiores estas, menores são as receitas líquidas. Essa variação das receitas líquidas em função das CAD's utilizadas, embora fosse um fato esperado, não chegou a inviabilizar o cultivo irrigado do feijão-caupi, pois para todas as CAD's utilizadas as receitas líquidas esperadas permaneceram num patamar relativamente alto, superiores a US\$ 450,00 ha ${ }^{-1}$, em toda a área do estado do Piauí, independentemente da data de semeadura e do nível de risco adotado.

Tomando-se, por exemplo, as receitas líquidas obtidas com o cultivo irrigado do feijão-caupi semeado em $1^{\mathrm{o}}$ de janeiro (Figura 3 - Anexo A), observa-se que, 
considerando um nível de risco de $25 \%$, ou seja, $75 \%$ de probabilidade de ocorrência, com uma CAD de $20 \mathrm{~mm}$, as receitas líquidas esperadas permaneceram entre US\$ 450,00 ha ${ }^{-1}$ e US\$ 525,00 ha ${ }^{-1}$. Quando a CAD passou para $40 \mathrm{~mm}$, mantendo-se o mesmo nível de risco (25\%), as receitas líquidas entre US\$ 450,00 ha ${ }^{-1} \mathrm{e}$ US\$ 525,00 $\mathrm{ha}^{-1}$ foram obtidas em, aproximadamente, 97,5\% da área do Estado; enquanto que no restante do Estado as receitas líquidas esperadas aumentam e ficam superiores a US\$525,00 $\mathrm{ha}^{-1}$. Aumentando-se a CAD para $60 \mathrm{~mm}$ e mantendo-se as demais condições constantes, as receitas líquidas em 19\% da área do Estado passam a ser maiores que US\$ 525,00 ha ${ }^{-1}$, e nos demais locais estas ficam entre US\$ 450,00 ha ${ }^{-1}$ e US\$ 525,00 ha ${ }^{-1}$. O mesmo comportamento das receitas líquidas em função da CAD pode ser observado para os níveis de risco $50 \%$ e $75 \%$, sendo a variação das receitas líquidas em função da CAD proporcionalmente maior em função do aumento do risco. Análise semelhante pode ser feita para as demais combinações de CAD e risco, nas diversas datas de semeaduras utilizadas neste estudo (Anexo A).

A variação das receitas líquidas em função da $\mathrm{CAD}$, para o cultivo irrigado do feijão-caupi, embora ocorra para todas as condições utilizadas neste estudo, foi maior nas épocas de ocorrência de chuvas (janeiro a abril, no centro-norte e novembro a março, no centro-sul do Estado) como pode ser observado nas Figuras 3 a 6, 13 e 14, apresentadas no Anexo A. Isso ocorreu porque, com a variação da capacidade de armazenamento de água do solo, a grande variabilidade espacial da distribuição das chuvas no Estado contribui para uma maior variabilidade das lâminas a serem aplicadas por irrigação, tendo reflexo direto sobre as receitas líquidas esperadas. Para as épocas de semeadura onde a ocorrência das chuvas é limitada e com pouca oscilação interanual, as lâminas de irrigação têm uma pequena variação entre os diversos locais do Estado, fato observado entre maio e setembro. Para a semeadura nesta época do ano, as receitas líquidas apresentam uma menor variação com a alteração da $\mathrm{CAD}$, ficando dentro de uma única classe de valores, US\$ 450,00 $\mathrm{ha}^{-1}$ a US\$ 525,00 ha ${ }^{-1}$, para todas as CAD's e níveis de risco utilizados, conforme visualiza-se nas Figuras 7 a 11 - Anexo A.

Para uma mesma $\mathrm{CAD}$, as receitas líquidas tiveram tendência de crescimento à medida que o risco envolvido aumentou, fato já evidenciado em outros trabalhos como 
os de Franke \& Dorfman (1998) e Andrade Júnior (2000), para as culturas do milho e feijão-caupi, respectivamente.

Considerando o feijão-caupi cultivado sem irrigação, onde o rendimento da cultura é altamente dependente da ocorrência das chuvas, a variação das receitas líquidas com a CAD foi maior quando comparada às obtidas com o cultivo irrigado, sendo estas crescentes com o aumento da CAD de $20 \mathrm{~mm}$ para $60 \mathrm{~mm}$. Nesse caso, a CAD foi fator limitante, chegando a inviabilizar o cultivo do feijão-caupi, quando combinada com determinados níveis de risco e épocas de semeadura onde a insuficiência das chuvas em determinadas regiões é restritiva ao cultivo, tal como pode ser observado nas Figuras 15 a 26 (Anexo B).

Para o cultivo de sequeiro do feijão-caupi com semeadura em $1^{\circ}$ de fevereiro, por exemplo, Figura 16 - Anexo B, mesmo com a ocorrência de chuvas em praticamente toda a área do Estado, considerando-se um risco de $25 \%$, para a CAD de $20 \mathrm{~mm}$ o cultivo foi inviável em $86 \%$ da área do Estado e menores que US\$ 225,00 ha ${ }^{-1}$, no restante da área. Considerando-se esse valor de receita líquida (US\$225,00 ha-1), como um valor mínimo atrativo para os produtores rurais da região, essa combinação de CAD e risco não seria atrativa financeiramente. Quando a CAD passou para $60 \mathrm{~mm}$, o percentual da área do Estado onde o cultivo foi inviável, caiu para 35\%, ocorrendo notadamente, na região semi-árida, muito embora em $80 \%$ da área do Estado as receitas líquidas tenham ficado abaixo de US\$225,00 $\mathrm{ha}^{-1}$. Considerando-se a possibilidade de um produtor se expor a um risco maior, ou seja, um risco de $75 \%$, onde as receitas líquidas poderiam ser igualadas ou superadas em apenas um em cada quatro anos, para a CAD de $20 \mathrm{~mm}$, a inviabilidade do cultivo estaria restrita à região sudeste do Estado, zona semi-árida, com $74 \%$ da área do Estado apresentando valores de receita líquida abaixo de US\$225,00 ha ${ }^{-1}$. Se a CAD fosse de $60 \mathrm{~mm}$, para esta mesma condição de risco e data de semeadura, o cultivo seria viável em todo o estado do Piaú, com o receita líquida mínima acima de US\$225,00 ha ${ }^{-1}$, exceto na região sudeste do Estado, com o crescimento das receitas líquidas acompanhando o padrão de crescimento dos valores de chuva durante o ciclo da cultura, ou seja, do sudeste para o noroeste do Estado, com as receitas líquidas esperadas chegando a ultrapassar os US\$ 525,00 ha ${ }^{-1}$. 
Para o cultivo de sequeiro com semeadura em $1^{\circ}$ de novembro (Figura $25-$ Anexo B), com o ciclo da cultura estendendo-se até o início de janeiro do ano seguinte, em cujo período as chuvas ocorrem em maior quantidade mais ao sul do Piauí, para um risco de 75\%, a utilização de um solo que resultasse em uma CAD de $20 \mathrm{~mm}$, tornaria o cultivo viável somente em $19 \%$ da área do Estado, sendo esta localizada ao sul, com receitas líquidas chegando apenas aos US\$ 300,00 ha ${ }^{-1}$. Ao se aumentar a CAD para $40 \mathrm{~mm}$, o cultivo já passaria a ser viável em 53\% da área do Estado, com aumento, também, dos valores das receitas líquidas, alcançando estas até US\$ 375,00 ha ${ }^{-1}$. Passando-se a CAD para $60 \mathrm{~mm}$, o cultivo seria viável em 65\% da área do Estado, com esta área se estendendo do sul até o centro do Estado e as receitas líquidas decrescendo neste sentido a partir de valores maiores que US\$ 525,00 ha ${ }^{-1}$ obtidos no sul do Estado, sendo que, em cerca de $25 \%$ da área do Estado as receitas líquidas superariam os US\$ 225,00 $\mathrm{ha}^{-1}$.

\subsection{Risco e viabilidade econômica da irrigação do feijão-caupi no estado do Piauí}

Considerando-se o risco envolvido no cultivo do feijão-caupi, as receitas líquidas tiveram comportamento diretamente proporcional a este, pois quanto maior o nível de risco, menores as lâminas requeridas e maiores os rendimentos esperados, resultando, conseqüentemente, em maiores receitas líquidas. Desta forma, à medida que o produtor se dispõe a correr um risco maior, as receitas líquidas esperadas tendem a aumentar, para todas as combinações possíveis de data de semeadura e CAD. Esse resultado está de acordo com os obtidos por Andrade Júnior (2000) e Franke (1996), em análise de viabilidade econômica sob condições de risco para as culturas do feijão-caupi e milho, respectivamente.

Para fins de decisão econômica sob condições de risco, esta depende do grau de aversão ao risco do produtor, sendo estes normalmente aversos ao risco preferindo obter um determinado retorno econômico com um menor risco. Considerando o cultivo irrigado do feijão-caupi, devido ao custo da água ser relativamente pequeno, dada a atual situação de gestão dos recursos hídricos no estado do Piauí, e a irrigação proporcionar 
uma maior estabilidade da produção, o crescimento das receitas líquidas com o aumento do risco foi bastante discreto. Neste caso, o cultivo do feijão-caupi no estado do Piauí foi economicamente viável para os três níveis de risco analisados e para todas as combinações de CAD e data de semeadura, sendo que as receitas líquidas sempre permaneceram superiores a US\$ 450,00 ha $\mathrm{ha}^{-1}$ (Figuras 3 a 14 - Anexo A). Desta forma, a viabilidade econômica da irrigação do feijão-caupi se confirma, independentemente do risco a ser considerado.

A variação das receitas líquidas com o risco, para cada combinação de data de semeadura e CAD, considerando-se o cultivo do feijão-caupi irrigado, pode ser visualizada nas Figuras 3 a 14 - Anexo A. Por exemplo, considerando-se o cultivo do feijão-caupi com semeadura em $1^{\circ}$ de fevereiro, Figura 4 - Anexo A, para uma CAD de $60 \mathrm{~mm}$, o risco de $25 \%$ proporcionaria receitas líquidas maiores que US $\$ 525,00 \mathrm{ha}^{-1}$ na região norte do Estado, representando cerca de 19\% de sua área, ficando o restante entre US\$ 450,00 ha ${ }^{-1}$ e US\$ 525,00 ha-1. Desta forma, em três de cada quatro anos, as receitas líquidas superariam US\$ 525,00 $\mathrm{ha}^{-1}$ em $19 \%$ da área do Piauí; enquanto que no restante do Estado as receitas ficariam no intervalo de US\$ 450,00 $\mathrm{ha}^{-1}$ a US\$ 525,00 ha ${ }^{-1}$. Quando o risco aumentou para 50\%, em 2 de cada 4 anos, as receitas líquidas maiores que US\$ 525,00 ha ${ }^{-1}$ passariam a ocorrer em $68 \%$ da área do Estado e para um risco de $75 \%$, ou seja, em um de cada quatro anos, praticamente em todo o Estado as receitas ficariam acima de US\$ 525,00 ha ${ }^{-1}$, considerando a CAD de $60 \mathrm{~mm}$. Para a semeadura em $1^{\circ}$ de julho, Figura 9 - Anexo A, época em que praticamente não ocorrem chuvas consideráveis no Estado, o aumento do risco de 25\% para 75\%, considerando-se a CAD de $60 \mathrm{~mm}$, proporcionou um aumento bastante discreto nas receitas líquidas esperadas, ao ponto das classes de receitas liquidas em todo o Estado permanecerem entre US\$ 450,00 ha $\mathrm{ha}^{-1}$ US \$ 525,00 ha ${ }^{-1}$ para as demais combinações de risco e CAD.

Na hipótese do cultivo de sequeiro, para os três níveis de risco utilizados $(25 \%$, $50 \%$ e $75 \%$ ), o cultivo do feijão-caupi mostrou-se viável economicamente somente em algumas regiões do Estado e para algumas combinações de data de semeadura e CAD. Dependendo do grau de aversão ao risco do produtor, pode-se definir estratégias quanto 
às regiões e épocas de semeadura para determinadas CAD's, visando a obtenção de resultados economicamente viáveis do cultivo de sequeiro do feijão-caupi. Considerando-se, por exemplo, o cultivo de sequeiro com semeadura em $1^{\circ}$ de janeiro (Figura 15 - Anexo B), para uma CAD de $20 \mathrm{~mm}$, o cultivo mostrou-se inviável em praticamente todo o Estado, quando o risco a que o produtor estivesse exposto fosse de $25 \%$. Para esta mesma CAD, com o aumento do risco para $75 \%$, as receitas líquidas aumentaram proporcionando a obtenção de valores acima de US\$225,00 ha ${ }^{-1}$ na região noroeste do Estado, região esta de maior índice pluviométrico, tornando o cultivo atrativo para o produtor nesta área. Para a CAD de $60 \mathrm{~mm}$, mesmo com um risco menor (25\%), o cultivo foi inviável somente no sudeste do Estado, zona semi-árida, e com o aumento do risco para $75 \%$ o cultivo passou a ser viável economicamente em todo o Estado. Neste caso, as receitas líquidas na região sudeste do Estado permaneceram menores que US\$ $150,00 \mathrm{ha}^{-1}$, com crescimento considerável na direção sudestenoroeste, atingindo valores superiores a US\$ 525,00 $\mathrm{ha}^{-1}$.

\subsection{Datas de semeadura e viabilidade econômica da irrigação do feijão-caupi no estado do Piauí}

Pela análise das Figuras 3 a 14 - Anexo A, verifica-se que o cultivo irrigado do feijão-caupi no Piauí mostrou-se economicamente viável para todas as datas de semeadura utilizadas, independentemente da CAD e do nível de risco adotados, indicando que a prática da irrigação garante a viabilidade econômica do cultivo do feijão-caupi independentemente da época do ano. Esta indicação difere dos resultados obtidos por Bastos et al. (2000), que concluíram que o cultivo irrigado do feijão-caupi, em Teresina-PI, com semeadura em 15 de agosto e 15 de setembro, não é recomendável economicamente. No entanto, os referidos autores realizaram estudo simulando o cultivo na estação seca e considerando haver déficit hídrico à cultura devido ao manejo da irrigação, enquanto que neste trabalho a irrigação proporcionou o rendimento potencial da cultura pela ausência de déficit hídrico. 
Em trabalho semelhante a este, sendo, porém, realizado para apenas dois locais no estado do Piauí, microrregiões de Teresina e Litoral Piauiense, Andrade Júnior (2000) constatou que o cultivo irrigado do feijão-caupi foi viável independentemente da época do ano, desde que a irrigação fosse feita com um nível de manejo adequado, de modo a manter o solo sempre com uma umidade próxima à capacidade de campo.

As receitas líquidas variaram em função da data de semeadura, para uma mesma condição de $\mathrm{CAD}$ e risco, devido à ocorrência de chuvas no período de cultivo, o que contribuiu para a diminuição das lâminas brutas necessárias e, conseqüentemente, dos custos de produção. Entretanto, face ao custo relativamente baixo da água, a variação das receitas liquidas devido à época de cultivo foi pequena, podendo ser visualmente notada nos mapas temáticos apenas para combinações de CAD e risco maiores. Desta forma, mesmo nas épocas de ocorrência das chuvas, o cultivo irrigado foi mais atrativo do que o de sequeiro, conforme pode-se visualizar pelo comportamento das receitas líquidas nas Figuras 3 a 14 - Anexo A, e 15 a 26 - Anexo B, ressaltando-se porém, que nestas épocas, devido às condições climáticas, a cultura está mais sujeita a problemas fitossanitários. Resultado contrário foi obtido por Andrade Júnior (2000), que concluiu que o cultivo irrigado do feijão-caupi em dois locais do estado do Piauí, não se mostrou mais atrativo do que o de sequeiro, sendo que nas épocas de ocorrência das chuvas o cultivo de sequeiro foi mais atrativo do que o irrigado. Este resultado pode ser atribuído ao fato de que este autor considerou a ocorrência de déficit hídrico mesmo com a utilização da irrigação, resultando em queda de rendimento da cultura.

Para o cultivo irrigado do feijão-caupi, adotando-se o risco de $25 \%$ e CAD de $20 \mathrm{~mm}$, por exemplo, para todas as datas de semeadura utilizadas as receitas líquidas em todo o Estado permaneceram entre US\$ 450,00 ha ${ }^{-1}$ e US\$ 525,00 ha ${ }^{-1}$. Ao se combinar o nível de risco de $75 \%$ com a CAD de $60 \mathrm{~mm}$, as semeaduras em $1^{\circ}$ de janeiro e $1^{\circ}$ de fevereiro (Figuras 3 e 4 - Anexo A) proporcionariam receitas líquidas maiores que US\$ 525,00 ha ${ }^{-1}$ em praticamente todo o Estado. Para as datas de semeadura a partir de abril até outubro, período onde as chuvas são escassas, as receitas líquidas esperadas apresentam uma pequena redução em toda a área do Estado, passando para o intervalo de US\$ 450,00 ha- ${ }^{-1}$ a US\$ 525,00 ha- . Valores acima de US\$ 525,00 ha-1 foram obtidos 
em algumas regiões, quando a semeadura ocorre de novembro em diante, conforme visualiza-se nas Figuras 3 a 14 - Anexo A.

A semeadura em $1^{\circ}$ de fevereiro, considerando uma estratégia de planejamento do cultivo irrigado do feijão-caupi em nível estadual, foi a que se mostrou mais favorável, pois apresentou maiores áreas do Estado ocupadas com classes de receitas líquidas mais elevadas. Nesta época, as precipitações pluviométricas que ocorrem em todo o Estado, contribuem para o suprimento hídrico da cultura, reduzindo os custos de produção pela redução das lâminas de irrigação a serem aplicadas. Para a semeadura nesta data, Figura 4 - Anexo A, observa-se que, para um risco de 75\% mesmo em uma condição de CAD igual a $20 \mathrm{~mm}$, as receitas líquidas foram superiores a US\$ 525,00 ha ${ }^{-1}$ em 24\% da área do Estado, notadamente na sua região norte. Quando a CAD passou para $60 \mathrm{~mm}$, mantendo-se o mesmo nível de risco, as receitas líquidas foram superiores a US\$ 525,00 $\mathrm{ha}^{-1}$ em quase 96\% da área do Estado.

Para o cultivo do feijão-caupi sem irrigação, existe viabilidade econômica apenas para algumas datas de semeadura, notadamente de janeiro a abril e de outubro a dezembro e para algumas combinações de $\mathrm{CAD}$, risco e região de cultivo. Nas datas de semeaduras de maio a setembro (Figuras 19 a 23 - Anexo B), o cultivo de sequeiro mostrou-se inviável para todos os locais do Estado e para todas as combinações de CAD e risco, devido aos elevados déficits hídricos ocorridos durante o ciclo da cultura, causados pela escassez das chuvas, o que restringiu e até mesmo impossibilitou a produção da cultura. Estes resultados estão de acordo com os obtidos Bastos et al. (2000) e Andrade Júnior (2000), que constataram que não é possível o cultivo de sequeiro do feijão-caupi, nos municípios de Teresina e Parnaíba-PI, no segundo semestre do ano, devido aos baixos índices pluviométricos. Desta forma, verifica-se que para o cultivo de sequeiro do feijão-caupi, a escolha da época adequada para o cultivo torna-se indispensável para a obtenção de retornos econômicos satisfatórios.

Andrade Júnior (2000) verificou que o cultivo de sequeiro do feijão-caupi no município de Teresina, nas datas de semeaduras $1^{\circ}$ de fevereiro e $1^{\circ}$ de março, foi mais rentável que o irrigado. Contudo, este autor considerou haver déficit hídrico no cultivo irrigado devido à condições de manejo de irrigação, resultando em queda de rendimento; 
enquanto que, neste trabalho, a cultura não sofreu déficit hídrico, sendo garantido o rendimento potencial da cultura através da irrigação.

A Tabela 3 apresenta os percentuais de cada classe temática de receitas líquidas obtidas com o cultivo de sequeiro do feijão-caupi para diferentes datas de semeadura, considerando-se uma CAD de $40 \mathrm{~mm}$ e um risco de $75 \%$. Para a semeadura em $1^{\circ}$ de janeiro, o cultivo mostrou-se viável em mais de 99\% da área do Estado e 75\% da área do Estado apresentando receitas líquidas maiores que US\$225,00 ha $\mathrm{ha}^{-1}$, com tendência de crescimento destas no sentido sudeste-noroeste, acompanhando as isoietas de chuva no Estado, atingindo valores de até US\$ 525,00 $\mathrm{ha}^{-1}$. Observou-se uma pequena área onde o cultivo se mostrou inviável, localizada bem ao sudeste do Estado, Figura 15 - Anexo B. Para as mesmas condições de CAD e risco, na semeadura em $1^{\circ}$ de fevereiro o cultivo passa a ser viável em $100 \%$ da área do Estado, com o padrão de crescimento das receitas semelhante ao exemplo anterior e aumentando as áreas ocupadas por valores de US\$ 75,00 ha ${ }^{-1}$ a US\$ 225,00 $\mathrm{ha}^{-1}$ e aparecimento de classes de receitas líquidas acima de US\$ 525,00 ha ${ }^{-1}$ (Figura 16 - Anexo B).

Para a semeadura para $1^{\circ}$ de março, mantendo-se a mesma combinação de risco e $\mathrm{CAD}$, apesar de ainda existir uma pequena região do Estado apresentando valores acima de US\$ 525,00 ha ${ }^{-1}$, ocorre a queda de valores de receitas líquidas com o aumento das áreas com valores abaixo de US\$ 150,00 ha ${ }^{-1}$, com 19,9\% da área do Estado apresentando receitas líquidas negativas. A semeadura ocorrendo em $1^{\circ}$ de abril, Figura 18 - Anexo B, somente no norte do Estado o cultivo é viável, com $82,2 \%$ da área do Estado apresentando receitas líquidas negativas. Para a semeadura no período de $1^{\mathrm{o}}$ de maio a $1^{\circ}$ de setembro, o cultivo não irrigado mostrou-se inviável em todo o Estado, ocorrendo o crescimento dos valores de receitas líquidas, e de maiores percentuais da área do Estado ocupados por estas, com o atraso da semeadura a partir de outubro até dezembro, aparecendo novamente áreas onde o cultivo é viável, notadamente na região sul do Estado, como pode-se constatar pela observação das Figuras 19 a 26 - Anexo B. 
Tabela 3. Percentuais da área do estado do Piauí ocupadas por diferentes classes de receita líquida (RL) obtidas com o cultivo de sequeiro do feijão-caupi em diferentes datas de semeadura, considerando a CAD de $40 \mathrm{~mm}$ e risco $75 \%$

RL

Datas de semeadura (dia/mês)

$\begin{array}{lllllllllllll}\left.{\text { (US } \$ h^{-1}}^{-1}\right) & 1 / 1 & 1 / 2 & 1 / 3 & 1 / 4 & 1 / 5 & 1 / 6 & 1 / 7 & 1 / 8 & 1 / 9 & 1 / 10 & 1 / 11 & 1 / 12\end{array}$

$\begin{array}{lllllllllllll}<0 & 0,8 & 0 & 19,9 & 82,2 & 100,0 & 100,0 & 100,0 & 100,0 & 100,0 & 78,1 & 47,2 & 4,1\end{array}$

$\begin{array}{lllllllllllll}0-75 & 5,4 & 0,9 & 23,3 & 3,5 & 0,0 & 0,0 & 0,0 & 0,0 & 0,0 & 7,0 & 19,5 & 15,6\end{array}$

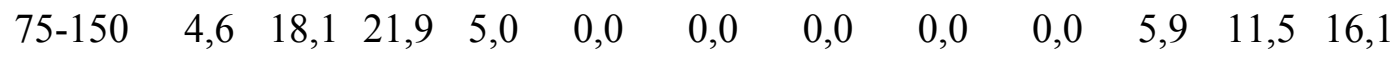

$\begin{array}{lllllllllllll}150-225 & 14,3 & 21,0 & 4,7 & 3,3 & 0,0 & 0,0 & 0,0 & 0,0 & 0,0 & 5,2 & 6,0 & 17,4\end{array}$

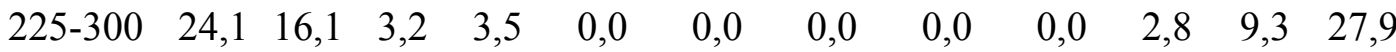

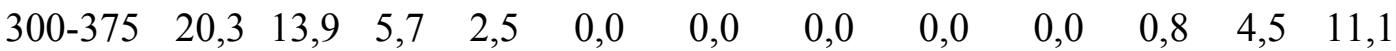

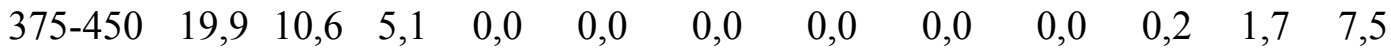

$\begin{array}{lllllllllllll}450-525 & 10,6 & 9,0 & 9,6 & 0,0 & 0,0 & 0,0 & 0,0 & 0,0 & 0,0 & 0,0 & 0,3 & 0,3\end{array}$

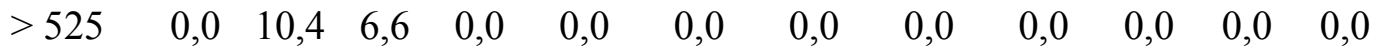

\subsection{Locais de cultivo e viabilidade econômica da irrigação do feijão-caupi no estado do Piauí}

Para o cultivo irrigado do feijão-caupi no estado do Piauí, não houve restrição quanto ao local de cultivo, pois as receitas líquidas foram sempre positivas e maiores do que US\$ 450,00 ha ${ }^{-1}$ em todas as regiões do Estado, para todas as combinações de CAD e risco simuladas, conforme visualiza-se nas Figuras 3 a 14 - Anexo A. As receitas líquidas esperadas cresceram do sudeste para o noroeste do Estado, acompanhando o crescimento do índice pluviométrico. Desta forma, as menores receitas líquidas foram sempre obtidas no sudeste do Estado (região semi-árida), e as maiores, na região noroeste do Estado, onde ocorrem os maiores índices pluviométricos, por reduzir os custos relativos à aplicação de água. Todavia, por estes custos serem relativamente pequenos, a amplitude dos valores de receitas líquidas foi também pequena, o que permitiu a obtenção de valores de receitas líquidas dentro de apenas duas classes temáticas, de US\$ 450,00 ha ${ }^{-1}$ a US\$ 525,00 ha ${ }^{-1}$ e maiores que US\$ 525,00 ha ${ }^{-1}$, para 
todos as regiões do Estado e para todas as combinações de CAD, risco e época de cultivo. Como exemplo, para a simulação da semeadura em $1^{\circ}$ de julho, época em que praticamente não ocorrem chuvas no Piauí (Figura 9 - Anexo A), para todas as combinações de CAD e risco, as receitas se mantêm entre US\$ 450,00 ha ${ }^{-1}$ e US\$ 525,00 $\mathrm{ha}^{-1}$ em todo o estado do Piauí.

Considerando-se o cultivo de sequeiro, algumas regiões apresentaram restrição ao cultivo, especialmente no sudeste do Estado, onde mesmo com a combinação mais favorável de data de semeadura, $\mathrm{CAD}$ e risco, o cultivo apresentou baixos retornos econômicos pelo fato de que as chuvas ocorridas durante o ciclo da cultura não serem suficientes para a obtenção de um rendimento compatível. Este resultado concorda com os resultados obtidos por Morais et al. (2001) quando afirmaram que a distribuição espacial da precipitação pluvial em uma determinada região é um dos fatores que refletem diretamente os diferentes níveis de desenvolvimento regional, principalmente o agrícola, pois dentre todas as atividades produtivas a agricultura é a que apresenta maior dependência da ocorrência das chuvas, sendo esta a principal responsável pela variabilidade espacial das produções agrícolas anuais.

Na região sudeste do Estado (zona semi-árida), o cultivo de sequeiro do feijãocaupi só mostrou-se economicamente viável quando a semeadura ocorre em janeiro ou fevereiro (Figuras 15 e 16 - Anexo B), desde que em solos com CAD acima de $40 \mathrm{~mm}$ e, ainda assim, estando o agricultor disposto a se expor a um risco alto (75\%).

Nas regiões norte, centro-sul e sudoeste do Estado, incluindo o vale do Rio Gurguéia, o cultivo de sequeiro do feijão-caupi nas épocas de ocorrência de chuvas, mostrou-se viável para um maior número de combinações de $\mathrm{CAD}$ e risco, conforme constata-se pela visualização das Figuras 15, 16, 17 e 26 - Anexo B. Tomando-se, por exemplo, a semeadura em $1^{\circ}$ de fevereiro (Figura 16 - Anexo B), nestas regiões, o cultivo do feijão-caupi para as combinações de risco 50\% e 75\% com as CAD's de $40 \mathrm{~mm}$ e $60 \mathrm{~mm}$, mostrou-se economicamente viável, muito embora as receitas líquidas para algumas condições tenham sido relativamente baixas. Desta forma, a viabilidade do cultivo de sequeiro do feijão-caupi nestas regiões, está condicionada à semeadura em 
algumas datas e em solos com maiores CAD's, com o agricultor estando disposto a correr um risco maior.

As Tabelas 4 e 5 apresentam valores de precipitação pluviométrica efetiva e lâminas brutas necessárias durante o ciclo da cultura, rendimento esperado, custo da energia, custos totais de produção e receitas líquidas esperadas para alguns municípios do estado do Piauí (indicados na Figura 2), para as condições do cultivo irrigado e de sequeiro, respectivamente, considerando uma CAD de $40 \mathrm{~mm}$ e um risco de $75 \%$, para a semeadura em $1^{\circ}$ de fevereiro. As Tabelas 6 e 7 apresentam os mesmos índices, considerando a data de semeadura em $1^{\circ}$ de julho. Observa-se que a irrigação, mesmo na semeadura em fevereiro, onde ocorrem chuvas em todo o Estado, proporcionou aumento expressivo das receitas líquidas, especialmente onde as chuvas são mais irregulares, como no município de São Raimundo Nonato, onde a receita líquida esperada passou de US\$181,10 ha ${ }^{-1}$ (cultivo de sequeiro) para US\$ 523,34 ha ${ }^{-1}$ (cultivo irrigado).

Para a semeadura em $1^{\circ}$ de julho, considerando o cultivo de sequeiro (Tabela 7), observa-se que, em todos os municípios avaliados, o cultivo foi inviável, por causa dos baixos índices pluviométricos, o que impossibilitou a produção da cultura, resultando receitas líquidas negativas. Porém, com a prática da irrigação, o mesmo tornou-se economicamente viável, com as receitas líquidas ficando acima de US\$450,00 ha ${ }^{-1}$ para todos os municípios (Tabela 6). Isto ocorre porque, embora as lâminas brutas requeridas em alguns locais ultrapassem os $300 \mathrm{~mm}$, o custo da água foi relativamente pequeno, não havendo uma redução expressiva das receitas líquidas. Vale ressaltar que os custos médios relativos à aplicação da água obtidos neste trabalho, representados pelo custo da energia elétrica para o bombeamento, assemelharam-se aos obtidos por Andrade Júnior (2000), em estudo de viabilidade econômica do cultivo irrigado do feijão-caupi em Teresina e no litoral piauiense. Tomando-se, por exemplo, o município de Floriano, que fica no centro-oeste do Estado, onde o cultivo de sequeiro do feijão-caupi semeado em julho é inviável, a irrigação garantiu o rendimento potencial da cultura com uma lâmina requerida durante o ciclo de $368 \mathrm{~mm}$, gerando um custo com energia de US\$78,89 ha ${ }^{-1}$, cerca de $11,5 \%$ do custo total, resultando numa receita líquida de US\$ 465,02 ha ${ }^{-1}$. 
Para os municípios de Teresina e Parnaíba, considerando-se o cultivo irrigado com semeadura em $1^{\circ}$ de julho, por exemplo, para o total suprimento hídrico da cultura foi necessário a aplicação de lâminas de irrigação de $320 \mathrm{~mm}$ e $342 \mathrm{~mm}$, garantindo uma receita líquida de US\$ 475,41 ha ${ }^{-1}$ e US\$ 470,60 ha ${ }^{-1}$, respectivamente. Essas lâminas brutas de irrigação requeridas são semelhantes às obtidas por Bastos et al. (2002) e Andrade Júnior (2000), em trabalhos com o feijão-caupi nestes dois municípios.

Tabela 4. Precipitação efetiva (Pef), lâmina bruta de irrigação necessária (Lb), rendimento simulado (RS), custo da energia (CE), custo total (CT) e receita líquida simulada (RL) para o cultivo irrigado do feijão-caupi em alguns locais do estado do Piauí com semeadura em $1^{\circ}$ de fevereiro, para uma CAD de 40 $\mathrm{mm}$ e um risco de $75 \%$

\begin{tabular}{lcccccccc}
\hline Local & $\begin{array}{c}\text { Lat } \\
(\mathrm{sul})\end{array}$ & $\begin{array}{c}\text { Long } \\
(\text { oeste })\end{array}$ & $\begin{array}{c}\text { Pef } \\
(\mathrm{mm})\end{array}$ & $\begin{array}{c}\mathrm{Lb} \\
(\mathrm{mm})\end{array}$ & $\begin{array}{c}\mathrm{RS} \\
\left(\mathrm{kg} \mathrm{ha}^{-1}\right)\end{array}$ & $\begin{array}{c}\text { CE } \\
\left(\mathrm{US} \mathrm{ha}^{-1}\right)\end{array}$ & $\begin{array}{c}\mathrm{CT} \\
\left(\mathrm{US} \mathrm{ha}^{-1}\right)\end{array}$ & $\begin{array}{c}\mathrm{RL} \\
\left(\mathrm{US}^{\prime-1}\right)\end{array}$ \\
\hline Parnaíba & $02^{\circ} 54^{\prime}$ & $41^{\circ} 46^{\prime}$ & 497 & 56 & 2500 & 12,34 & 618,47 & 531,52 \\
Teresina & $05^{\circ} 05^{\prime}$ & $42^{\circ} 48^{\prime}$ & 630 & 18 & 2500 & 3,96 & 610,04 & 539,96 \\
Floriano & $06^{\circ} 46^{\prime}$ & $43^{\circ} 01^{\prime}$ & 633 & 43 & 2500 & 9,31 & 615,40 & 534,60 \\
Picos & $07^{\circ} 05^{\prime}$ & $41^{\circ} 28^{\prime}$ & 342 & 63 & 2500 & 13,52 & 619,60 & 530,40 \\
S. Rdo. Nonato & $09^{\circ} 01^{\prime}$ & $42^{\circ} 42^{\prime}$ & 335 & 96 & 2500 & 20,58 & 626,66 & 523,34 \\
Uruçuí & $07^{\circ} 14^{\prime}$ & $44^{\circ} 33^{\prime}$ & 386 & 83 & 2500 & 17,89 & 623,97 & 526,02 \\
Corrente & $10^{\circ} 27^{\prime}$ & $45^{\circ} 10^{\prime}$ & 455 & 74 & 2500 & 15,87 & 621,95 & 528,04 \\
\hline
\end{tabular}


Tabela 5. Precipitação efetiva (Pef), rendimento simulado (RS), custo da energia (CE), custo total $(\mathrm{CT})$ e receita líquida simulada $(\mathrm{RL})$ para o cultivo de sequeiro do feijão-caupi em alguns locais do estado do Piaú com semeadura em $1^{\circ}$ de fevereiro, para uma CAD de $40 \mathrm{~mm}$ e um risco de $75 \%$

\begin{tabular}{lccccccc}
\hline Local & $\begin{array}{c}\text { Lat } \\
(\mathrm{sul})\end{array}$ & $\begin{array}{c}\text { Long } \\
(\mathrm{oeste})\end{array}$ & $\begin{array}{c}\text { Pef } \\
(\mathrm{mm})\end{array}$ & $\begin{array}{c}\mathrm{RS} \\
\left(\mathrm{kg} \mathrm{ha}^{-1}\right)\end{array}$ & $\begin{array}{c}\mathrm{CE} \\
\left(\mathrm{USS} \mathrm{ha}^{-1}\right)\end{array}$ & $\begin{array}{c}\mathrm{CT} \\
\left(\mathrm{US} \mathrm{h} \mathrm{h}^{-1}\right)\end{array}$ & $\begin{array}{c}\mathrm{RL} \\
\left(\mathrm{US} \mathrm{h} \mathrm{h}^{-1}\right)\end{array}$ \\
\hline Parnaíba & $02^{\circ} 54^{\prime}$ & $41^{\circ} 46^{\prime}$ & 497 & 1626 & ---- & 322,91 & 425,06 \\
Teresina & $05^{\circ} 05^{\prime}$ & $42^{\circ} 48^{\prime}$ & 630 & 1993 & ---- & 322,91 & 593,92 \\
Floriano & $06^{\circ} 46^{\prime}$ & $43^{\circ} 01^{\prime}$ & 633 & 1589 & ---- & 322,91 & 408,03 \\
Picos & $07^{\circ} 05^{\prime}$ & $41^{\circ} 28^{\prime}$ & 342 & 1414 & ---- & 322,91 & 327,50 \\
S. Rdo. Nonato & $09^{\circ} 01^{\prime}$ & $42^{\circ} 42^{\prime}$ & 335 & 1096 & ---- & 322,91 & 181,10 \\
Uruçuí & $07^{\circ} 14^{\prime}$ & $44^{\circ} 33^{\prime}$ & 386 & 1329 & ---- & 322,91 & 288,10 \\
Corrente & $10^{\circ} 27^{\prime}$ & $45^{\circ} 10^{\prime}$ & 455 & 1257 & ---- & 322,91 & 255,23 \\
\hline
\end{tabular}

Tabela 6. Precipitação efetiva (Pef), lâmina bruta de irrigação necessária (Lb), rendimento simulado (RS), custo da energia (CE), custo total (CT) e receita líquida simulada $(\mathrm{RL})$ para o cultivo irrigado do feijão-caupi em alguns locais do estado do Piauí com semeadura em $1^{\circ}$ de julho, para uma CAD de $40 \mathrm{~mm}$ e um risco de $75 \%$

\begin{tabular}{lcccccccc}
\hline Local & $\begin{array}{c}\text { Lat } \\
(\mathrm{sul})\end{array}$ & $\begin{array}{c}\text { Long } \\
(\text { oeste })\end{array}$ & $\begin{array}{c}\text { Pef } \\
(\mathrm{mm})\end{array}$ & $\begin{array}{c}\mathrm{Lb} \\
(\mathrm{mm})\end{array}$ & $\begin{array}{c}\mathrm{RS} \\
\left(\mathrm{kg} \mathrm{ha}^{-1}\right)\end{array}$ & $\begin{array}{c}\mathrm{CE} \\
\left(\mathrm{US} \mathrm{ha}^{-1}\right)\end{array}$ & $\begin{array}{c}\mathrm{CT} \\
\left(\mathrm{USS} \mathrm{ha}^{-1}\right)\end{array}$ & $\begin{array}{c}\mathrm{RL} \\
\left(\mathrm{US} \mathrm{ha}^{-1}\right)\end{array}$ \\
\hline Parnaíba & $02^{\circ} 54^{\prime}$ & $41^{\circ} 46^{\prime}$ & 69 & 342 & 2500 & 73,32 & 679,40 & 470,60 \\
Teresina & $05^{\circ} 05^{\prime}$ & $42^{\circ} 48^{\prime}$ & 38 & 320 & 2500 & 68,51 & 674,59 & 475,41 \\
Floriano & $06^{\circ} 46^{\prime}$ & $43^{\circ} 01$ & 17 & 368 & 2500 & 78,89 & 684,97 & 465,02 \\
Picos & $07^{\circ} 05^{\prime}$ & $41^{\circ} 28^{\prime}$ & 7 & 327 & 2500 & 70,15 & 676,23 & 473,76 \\
S. Rdo. Nonato & $09^{\circ} 01^{\prime}$ & $42^{\circ} 42^{\prime}$ & 6 & 251 & 2500 & 53,83 & 659,90 & 490,10 \\
Uruçuí & $07^{\circ} 14^{\prime}$ & $44^{\circ} 33^{\prime}$ & 19 & 308 & 2500 & 65,98 & 672,06 & 477,94 \\
Corrente & $10^{\circ} 27^{\prime}$ & $45^{\circ} 10^{\prime}$ & 6 & 234 & 2500 & 50,19 & 656,27 & 493,73 \\
\hline
\end{tabular}


Tabela 7. Precipitação efetiva (Pef), rendimento simulado (RS), custo da energia (CE), custo total (CT) e receita líquida simulada (RL) para o cultivo de sequeiro do feijão-caupi em alguns locais do estado do Piauí com semeadura em $1^{\circ}$ de julho, para uma CAD de $40 \mathrm{~mm}$ e um risco de $75 \%$

\begin{tabular}{lccccccc}
\hline Local & $\begin{array}{c}\text { Lat } \\
(\mathrm{sul})\end{array}$ & $\begin{array}{c}\text { Long } \\
(\text { oeste })\end{array}$ & $\begin{array}{c}\text { Pef } \\
(\mathrm{mm})\end{array}$ & $\begin{array}{c}\mathrm{RS} \\
\left(\mathrm{kg} \mathrm{ha}^{-1}\right)\end{array}$ & $\begin{array}{c}\mathrm{CE} \\
\left(\mathrm{US} \mathrm{h} \mathrm{h}^{-1}\right)\end{array}$ & $\begin{array}{c}\mathrm{CT} \\
\left(\mathrm{US} \mathrm{ha}^{-1}\right)\end{array}$ & $\begin{array}{c}\mathrm{RL} \\
\left({\left.\mathrm{US} \$ \mathrm{ha}^{-1}\right)}^{-1}\right.\end{array}$ \\
\hline Parnaíba & $02^{\circ} 54^{\prime}$ & $41^{\circ} 46^{\prime}$ & 69 & 0 & ---- & 322,91 & $-322,91$ \\
Teresina & $05^{\circ} 05^{\prime}$ & $42^{\circ} 48^{\prime}$ & 38 & 0 & ---- & 322,91 & $-322,91$ \\
Floriano & $06^{\circ} 46^{\prime}$ & $43^{\circ} 01^{\prime}$ & 17 & 0 & ---- & 322,91 & $-322,91$ \\
Picos & $07^{\circ} 05^{\prime}$ & $41^{\circ} 28^{\prime}$ & 7 & 0 & ---- & 322,91 & $-322,91$ \\
S. Rdo. Nonato & $09^{\circ} 01^{\prime}$ & $42^{\circ} 42^{\prime}$ & 6 & 0 & ---- & 322,91 & $-322,91$ \\
Uruçuí & $07^{\circ} 14^{\prime}$ & $44^{\circ} 33^{\prime}$ & 19 & 0 & ---- & 322,91 & $-322,91$ \\
Corrente & $10^{\circ} 27^{\prime}$ & $45^{\circ} 10^{\prime}$ & 6 & 0 & ---- & 322,91 & $-322,91$ \\
\hline
\end{tabular}

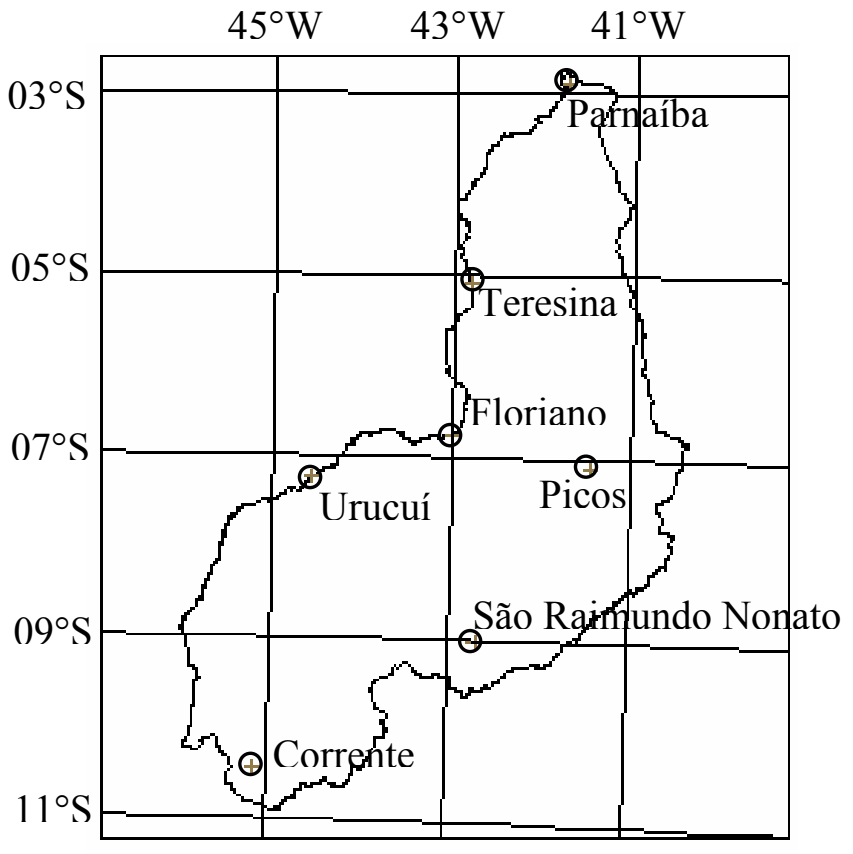

Figura 2 - Representação da posição geográfica, em relação ao estado do Piauí, dos municípios referenciados nas Tabelas 4, 5, 6 e 7 


\section{CONCLUSÕES}

Considerando as condições em que o estudo foi realizado e com base nos resultados obtidos, conclui-se que:

- O cultivo irrigado do feijão-caupi mostrou-se economicamente viável em todo o estado do Piauí, independentemente da data de semeadura, CAD e grau de risco utilizados.

- As receitas líquidas auferidas pelo cultivo do feijão-caupi variaram para as diversas regiões do estado do Piauí, em função da época de semeadura, da CAD e do nível de risco, especialmente na ausência da irrigação.

- O cultivo de sequeiro do feijão-caupi mostrou-se viável economicamente para algumas combinações de local, época de semeadura, CAD e nível de risco, estando mais condicionado à escolha dos locais e épocas de cultivo mais adequados, face à grande variabilidade espacial e temporal das chuvas.

- A semeadura em $1^{\circ}$ de fevereiro foi a que se mostrou mais favorável ao cultivo do feijão-caupi no Piauí, tanto para a condição com irrigação quanto para a de sequeiro, pois proporcionou a obtenção de maiores valores de receitas líquidas, bem como maiores áreas do Estado ocupadas por estes. 
ANEXOS 
Anexo A - Mapas de RL auferidas pelo cultivo irrigado do feijão-caupi no Piaú́

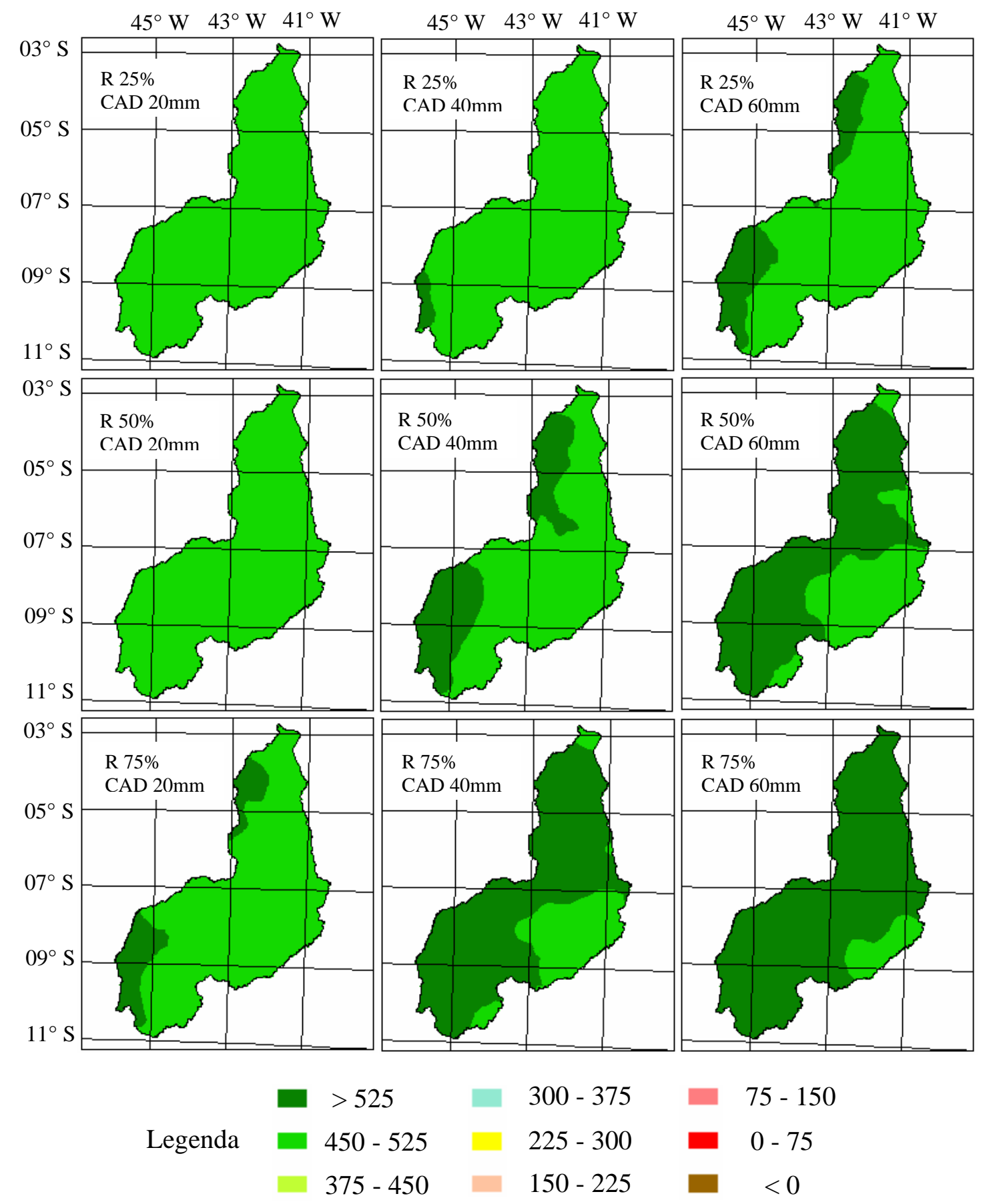

Figura 3 - Receitas líquidas (US\$ ha ${ }^{-1}$ ) obtidas com o cultivo irrigado do feijãocaupi no estado do Piauí, com semeadura em $1^{\circ}$ de janeiro e diferentes níveis de risco (R) e capacidade de água disponível no solo (CAD) 

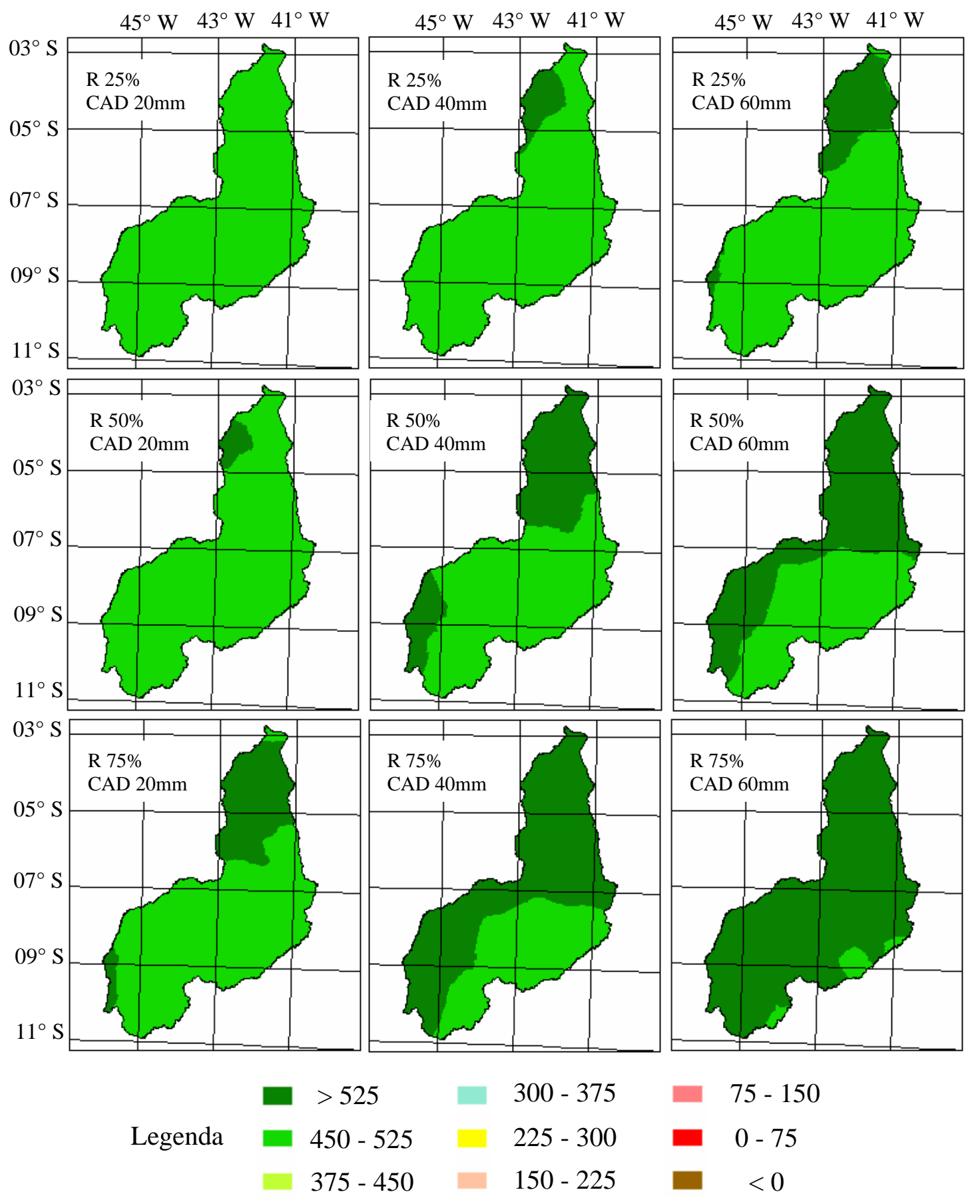

$$
\begin{aligned}
& 300-375 \\
& 225-300 \\
& 150-225
\end{aligned}
$$

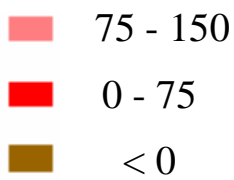

Figura 4 - Receitas líquidas (US\$ ha ${ }^{-1}$ ) obtidas com o cultivo irrigado do feijão-caupi no estado do Piauí, com semeadura em $1^{\circ}$ de fevereiro e diferentes níveis de risco (R) e capacidade de água disponível no solo (CAD) 

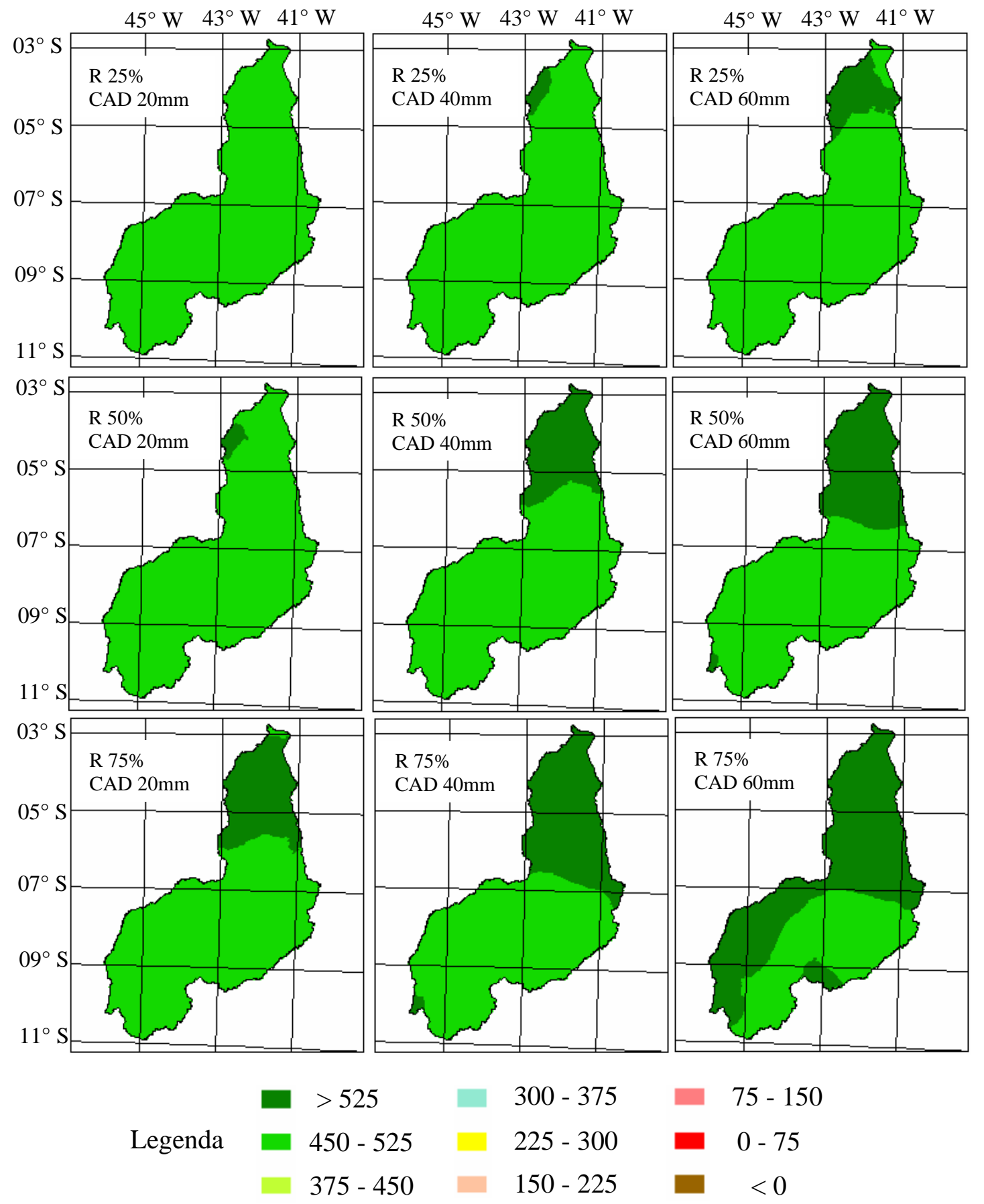

Figura 5 - Receitas líquidas (US\$ ha ${ }^{-1}$ ) obtidas com o cultivo irrigado do feijão-caupi no estado do Piauí, com semeadura em $1^{\circ}$ de março e diferentes níveis de risco (R) e capacidade de água disponível no solo (CAD) 

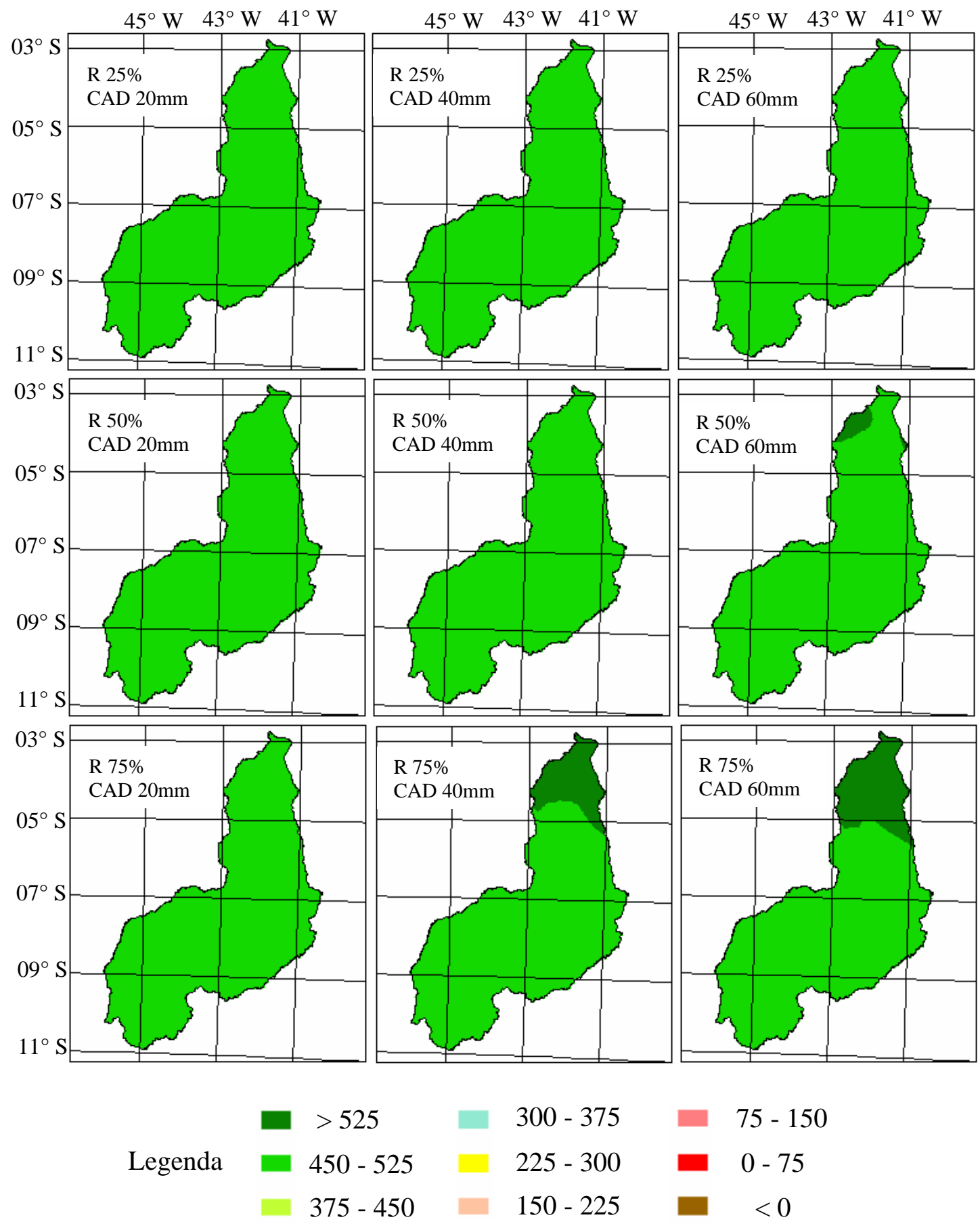

Figura 6 - Receitas líquidas (US\$ ha ${ }^{-1}$ ) obtidas com o cultivo irrigado do feijãocaupi no estado do Piauí, com semeadura em $1^{\circ}$ de abril e diferentes níveis de risco (R) e capacidade de água disponível no solo (CAD) 

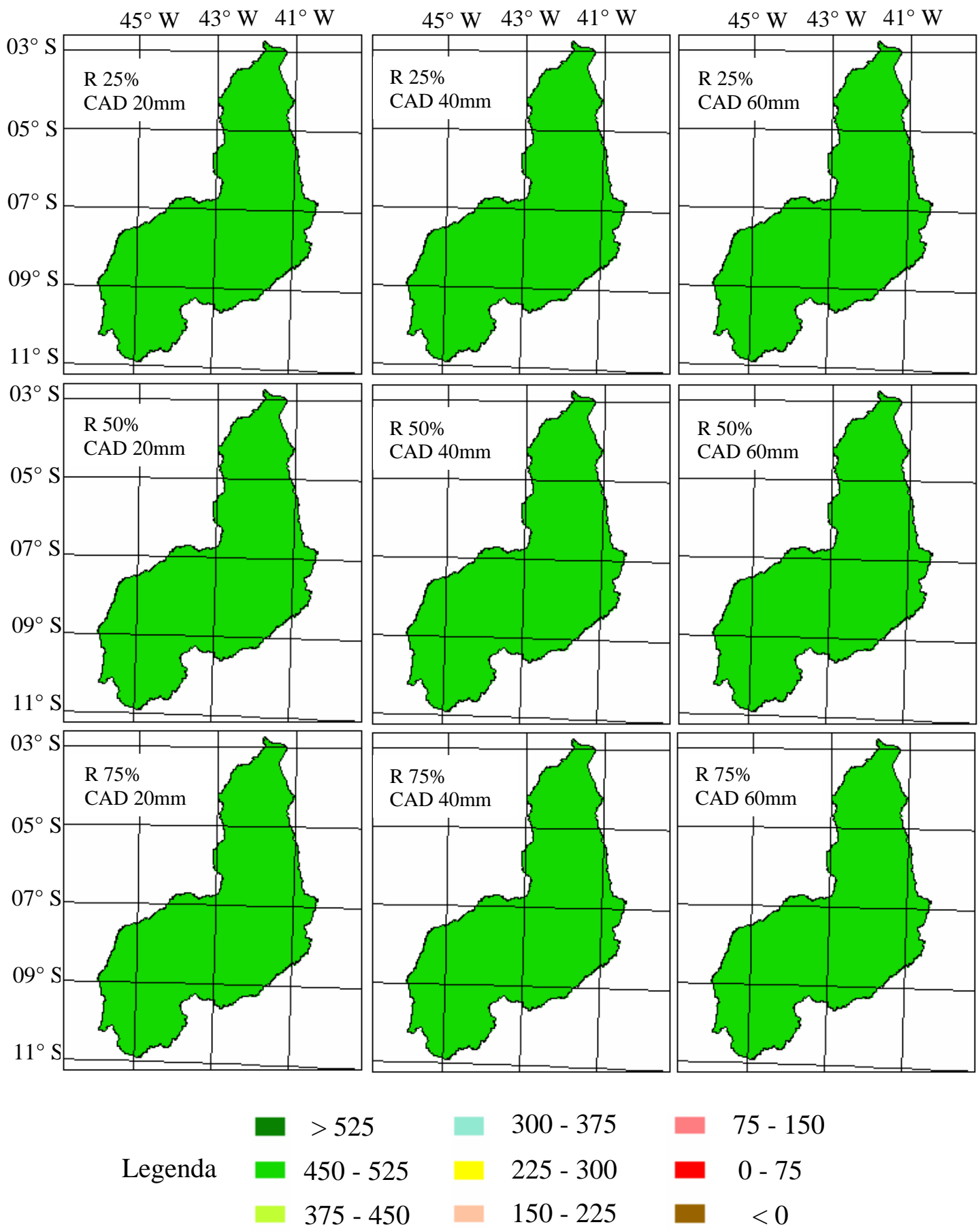

Figura 7 - Receitas líquidas (US\$ ha ${ }^{-1}$ ) obtidas com o cultivo irrigado do feijão-caupi no estado do Piauí, com semeadura em $1^{\circ}$ de maio e diferentes níveis de risco (R) e capacidade de água disponível no solo (CAD) 

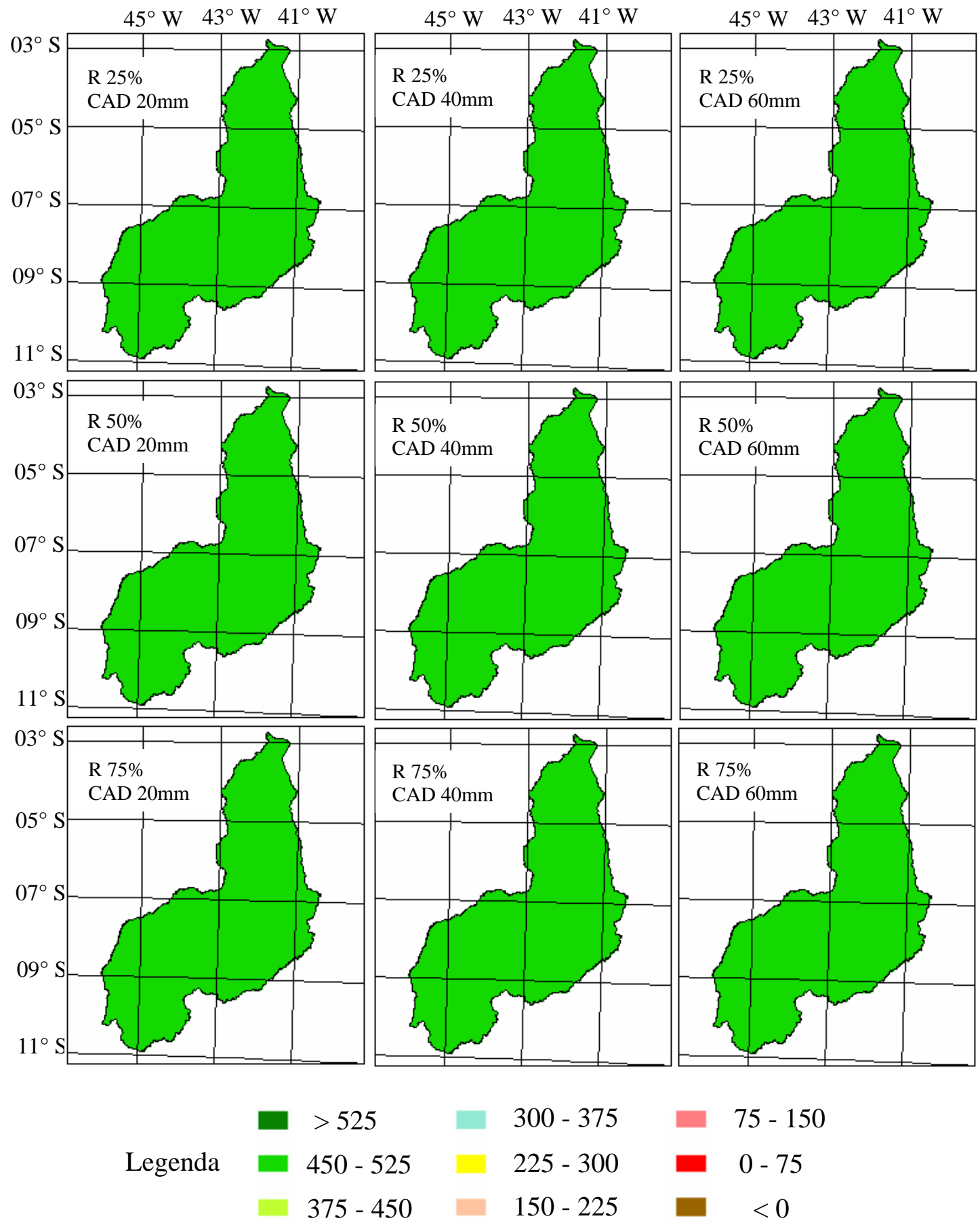

Figura 8 - Receitas líquidas (US\$ ha ${ }^{-1}$ ) obtidas com o cultivo irrigado do feijão-caupi no estado do Piauí, com semeadura em $1^{\circ}$ de junho e diferentes níveis de risco (R) e capacidade de água disponível no solo (CAD) 

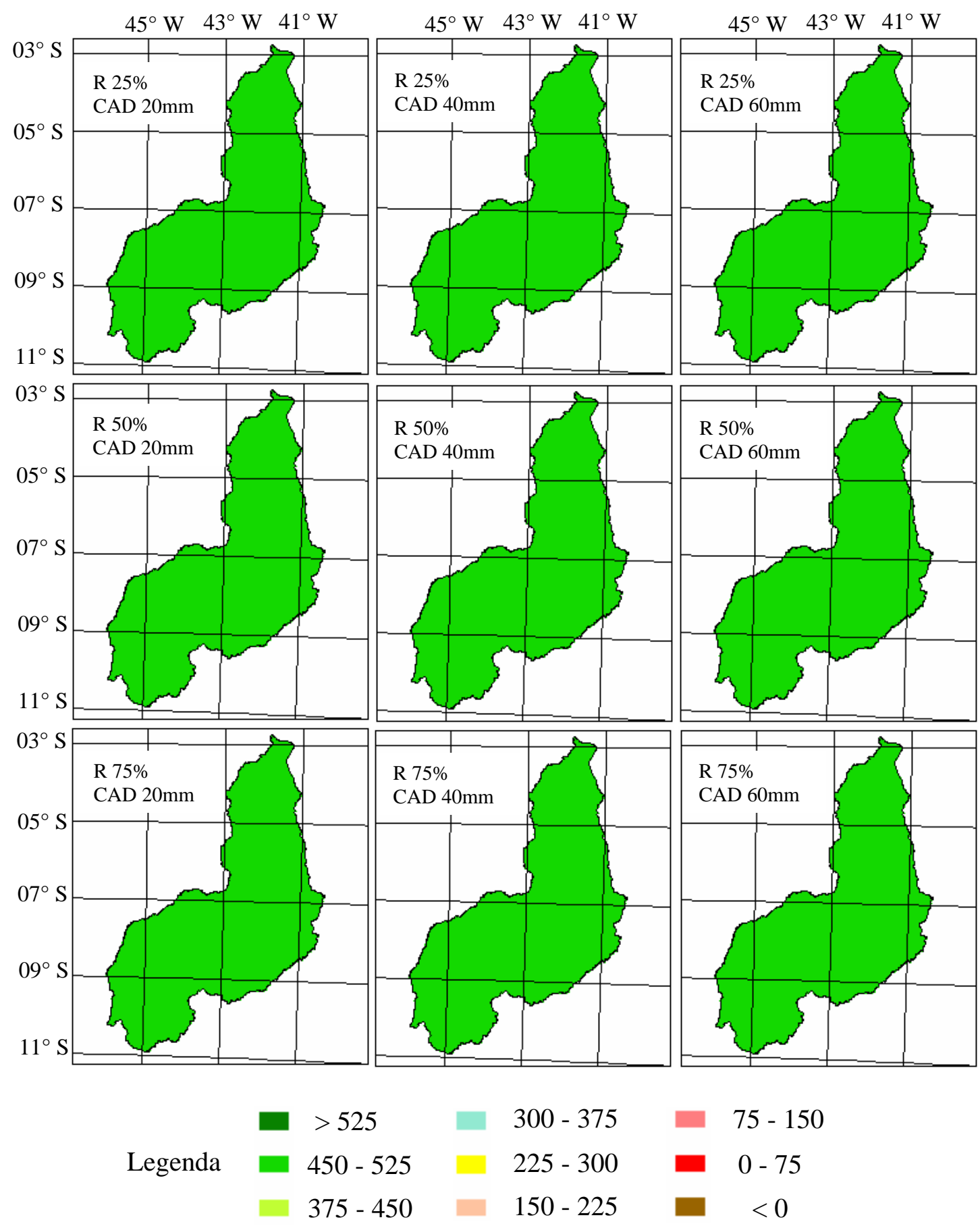

Figura 9 - Receitas líquidas (US\$ ha ${ }^{-1}$ ) obtidas com o cultivo irrigado do feijão-caupi no estado do Piauí, com semeadura em $1^{\circ}$ de julho e diferentes níveis de risco (R) e capacidade de água disponível no solo (CAD) 

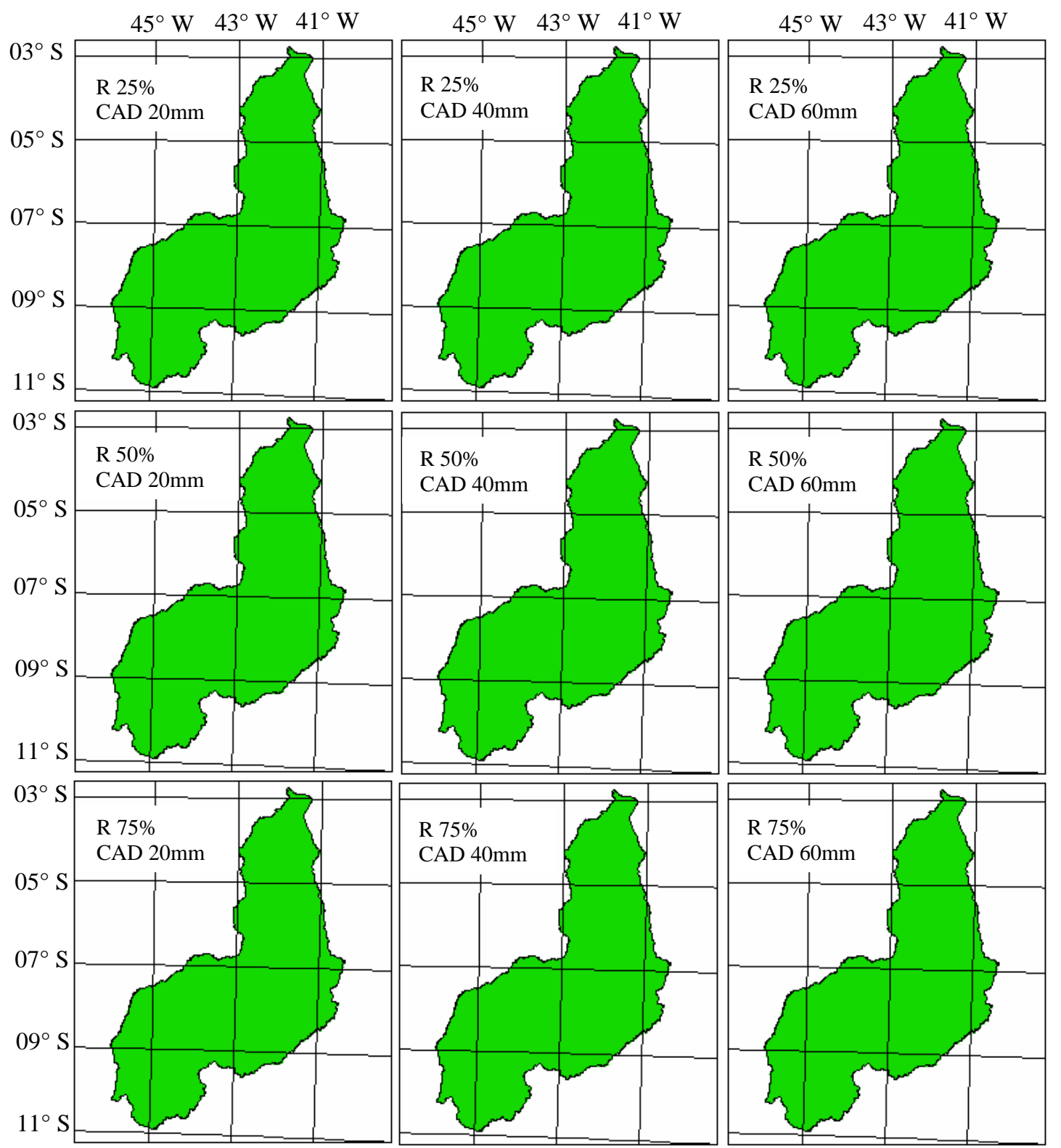

$$
\begin{array}{cllccc} 
& >525 & 300-375 & & 75-150 \\
\text { Legenda } & 450-525 & 225-300 & & 0-75 \\
& 375-450 & 150-225 & <0
\end{array}
$$

Figura 10 - Receitas líquidas (US\$ ha ${ }^{-1}$ ) obtidas com o cultivo irrigado do feijãocaupi no estado do Piauí, com semeadura em $1^{\circ}$ de agosto e diferentes níveis de risco (R) e capacidade de água disponível no solo (CAD) 


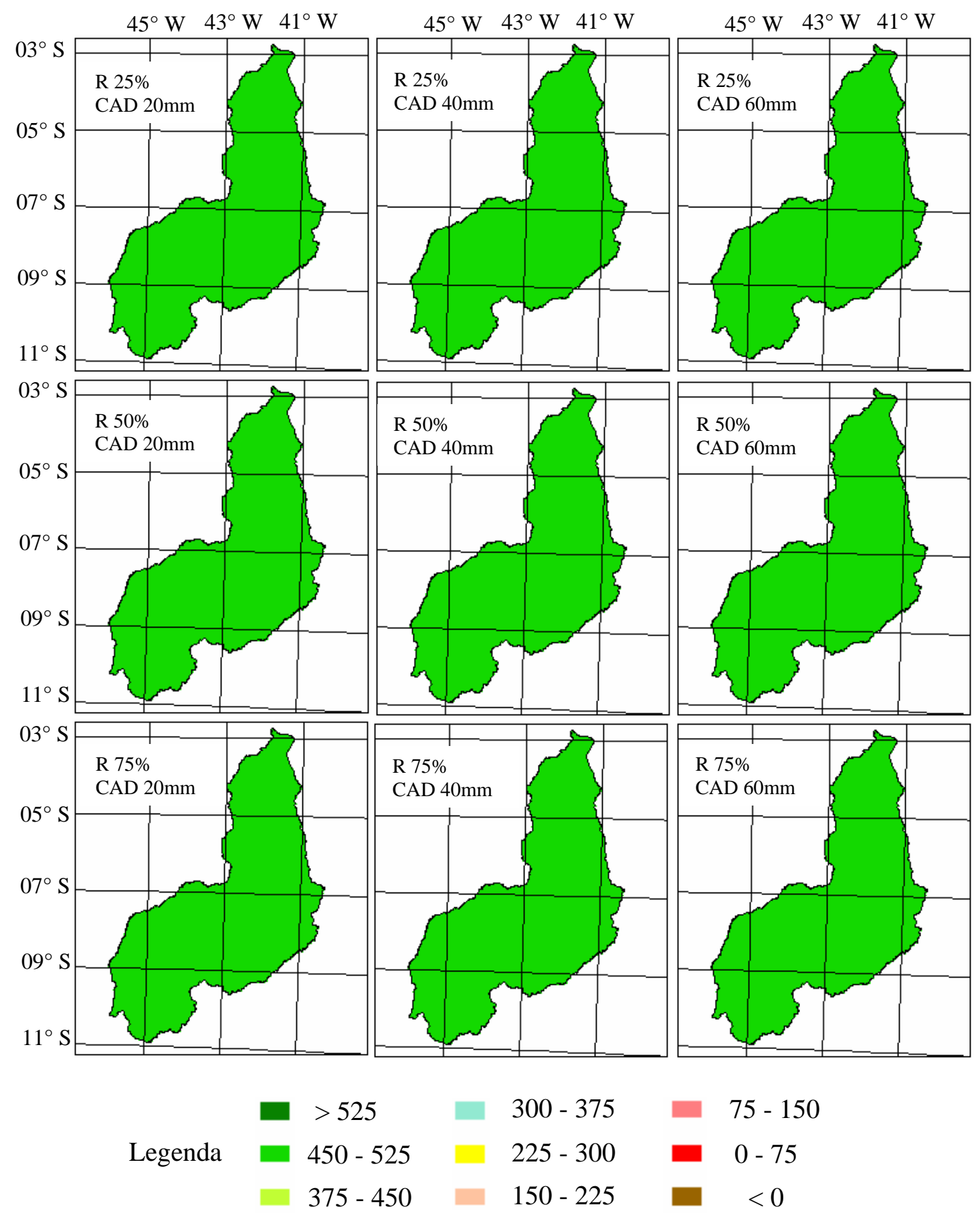

Figura 11 - Receitas líquidas (US\$ ha ${ }^{-1}$ ) obtidas com o cultivo irrigado do feijão-caupi no estado do Piauí, com semeadura em $1^{\circ}$ de setembro e diferentes níveis de risco $(\mathrm{R})$ e capacidade de água disponível no solo (CAD) 


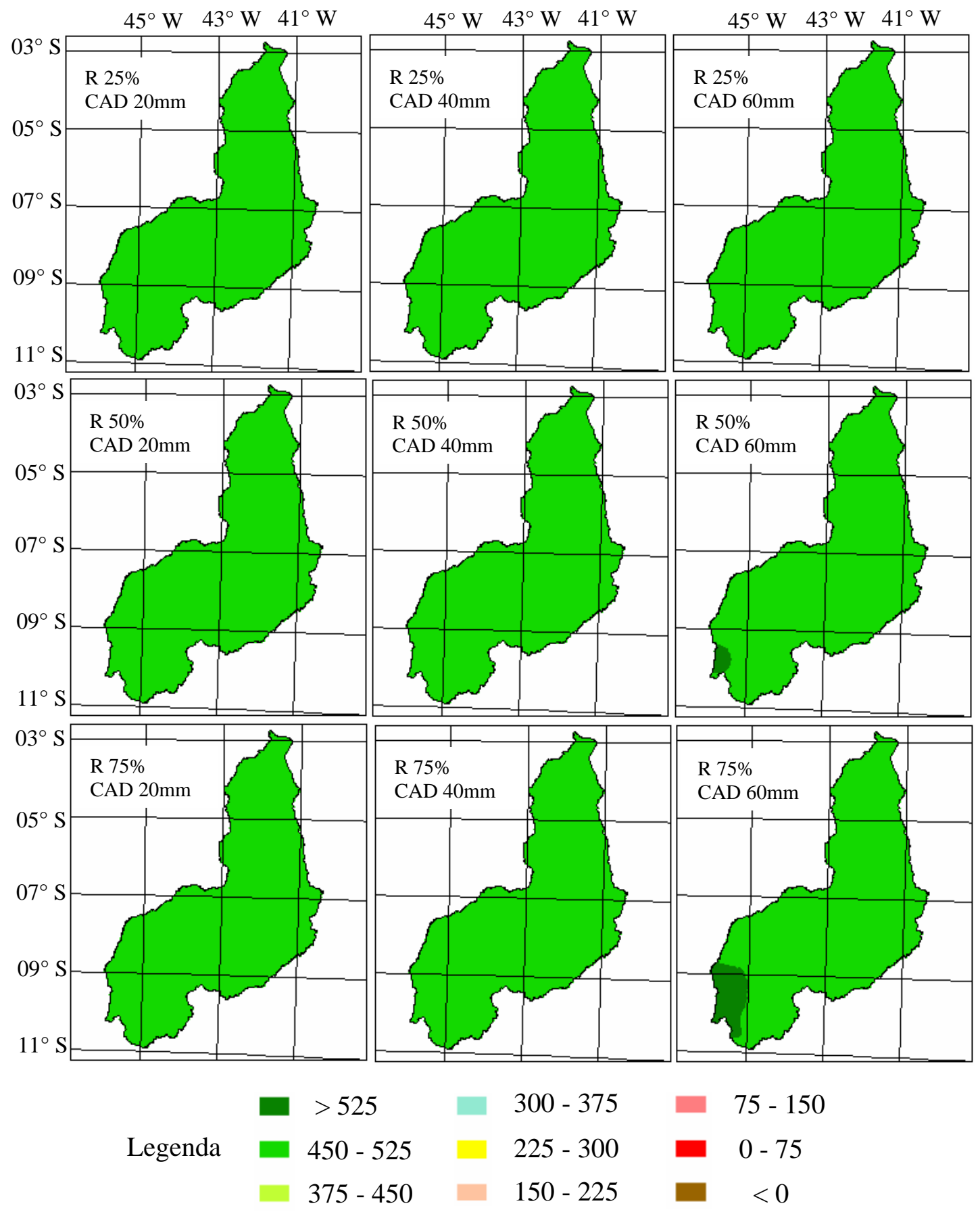

Figura 12 - Receitas líquidas (US\$ ha-1) obtidas com o cultivo irrigado do feijãocaupi no estado do Piauí, com semeadura em $1^{\circ}$ de outubro e diferentes níveis de risco (R) e capacidade de água disponível no solo (CAD) 


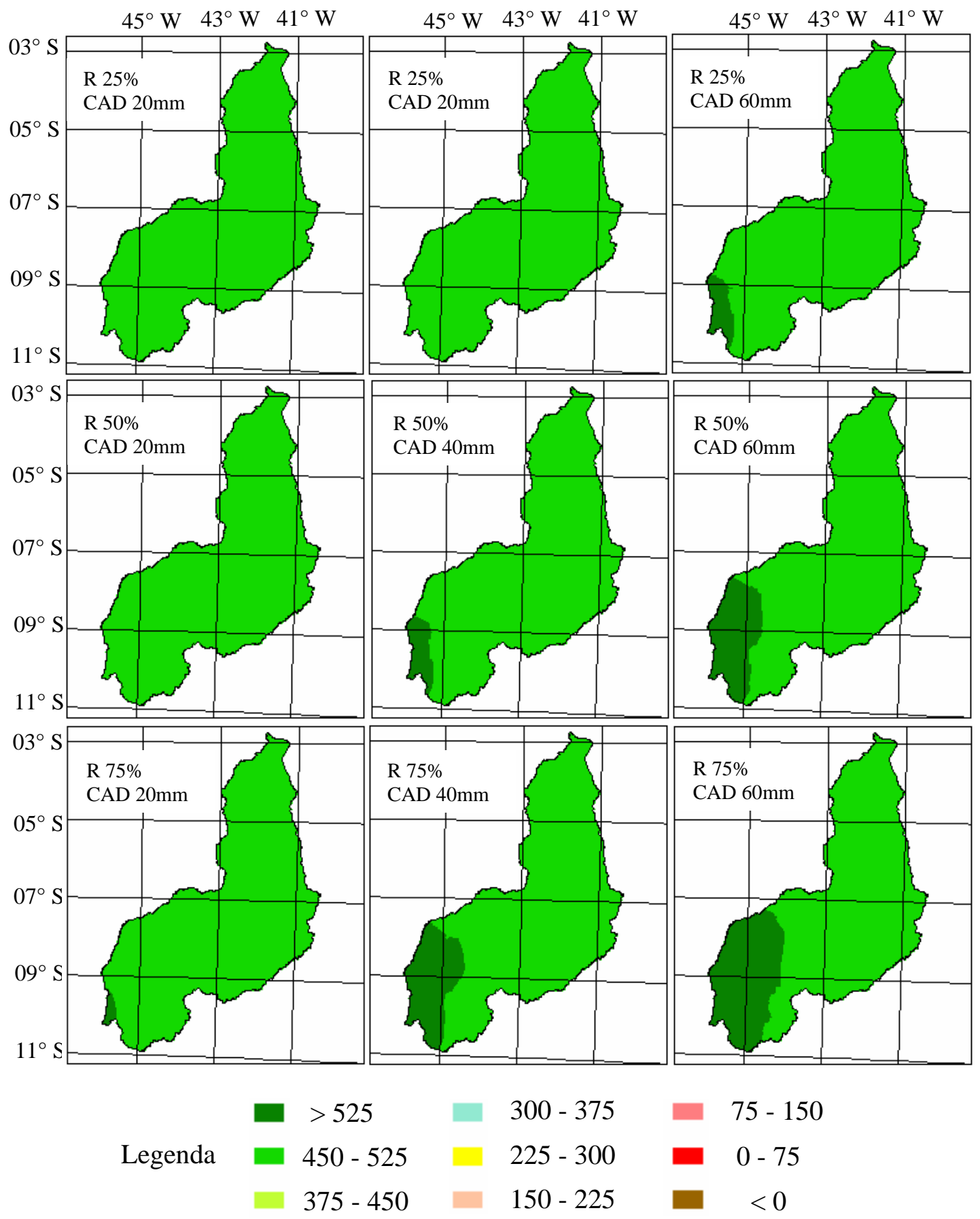

Figura 13 - Receitas líquidas (US\$ ha ${ }^{-1}$ ) obtidas com o cultivo irrigado do feijão-caupi no estado do Piauí, com semeadura em $1^{\circ}$ de novembro e diferentes níveis de risco (R) e capacidade de água disponível no solo (CAD) 


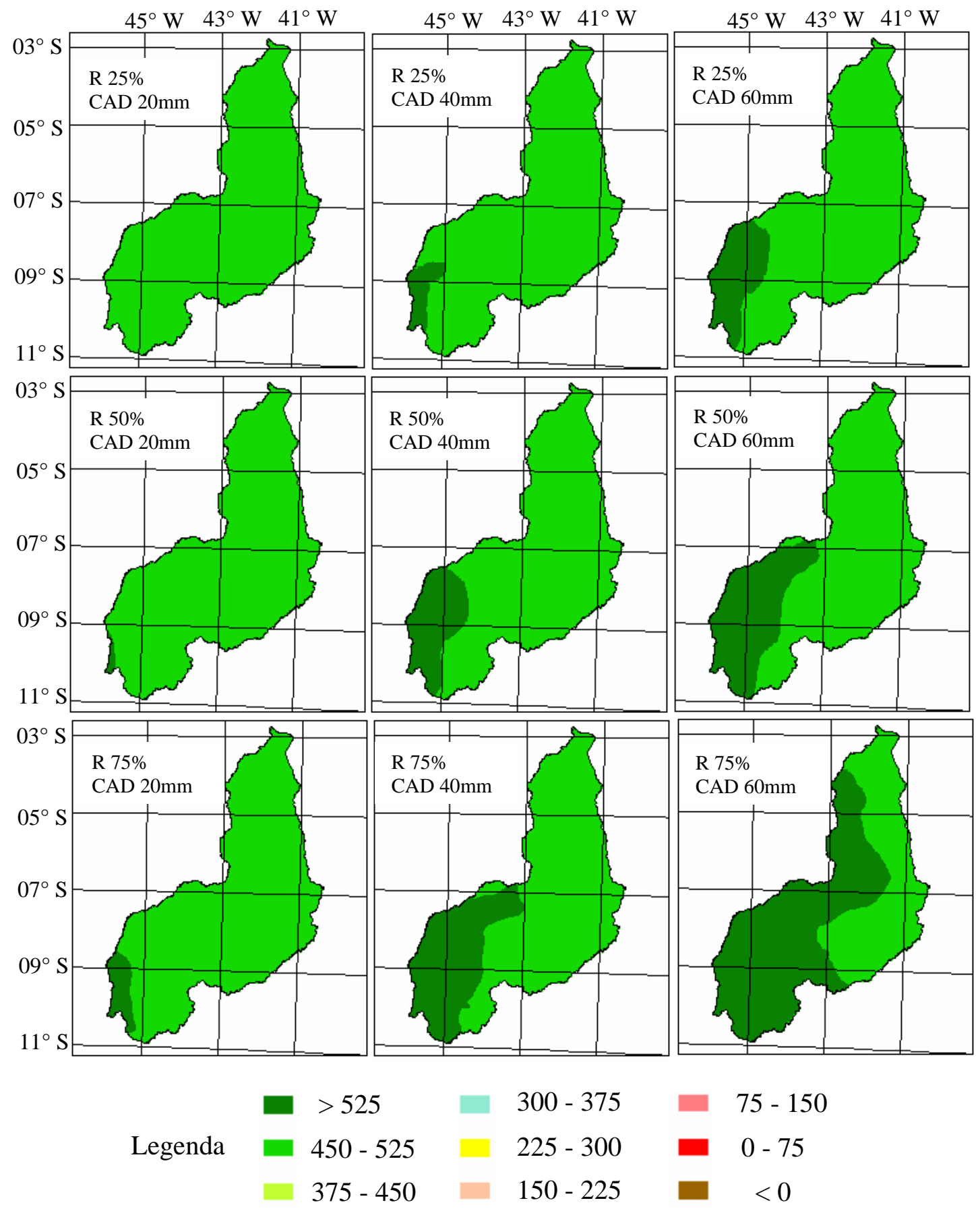

Figura 14 - Receitas líquidas (US\$ ha ${ }^{-1}$ ) obtidas com o cultivo irrigado do feijãocaupi no estado do Piauí, com semeadura em $1^{\circ}$ de dezembro e diferentes níveis de risco (R) e capacidade de água disponível no solo (CAD) 
Anexo B - Mapas de RL auferidas pelo cultivo de sequeiro do feijão-caupi no Piauí

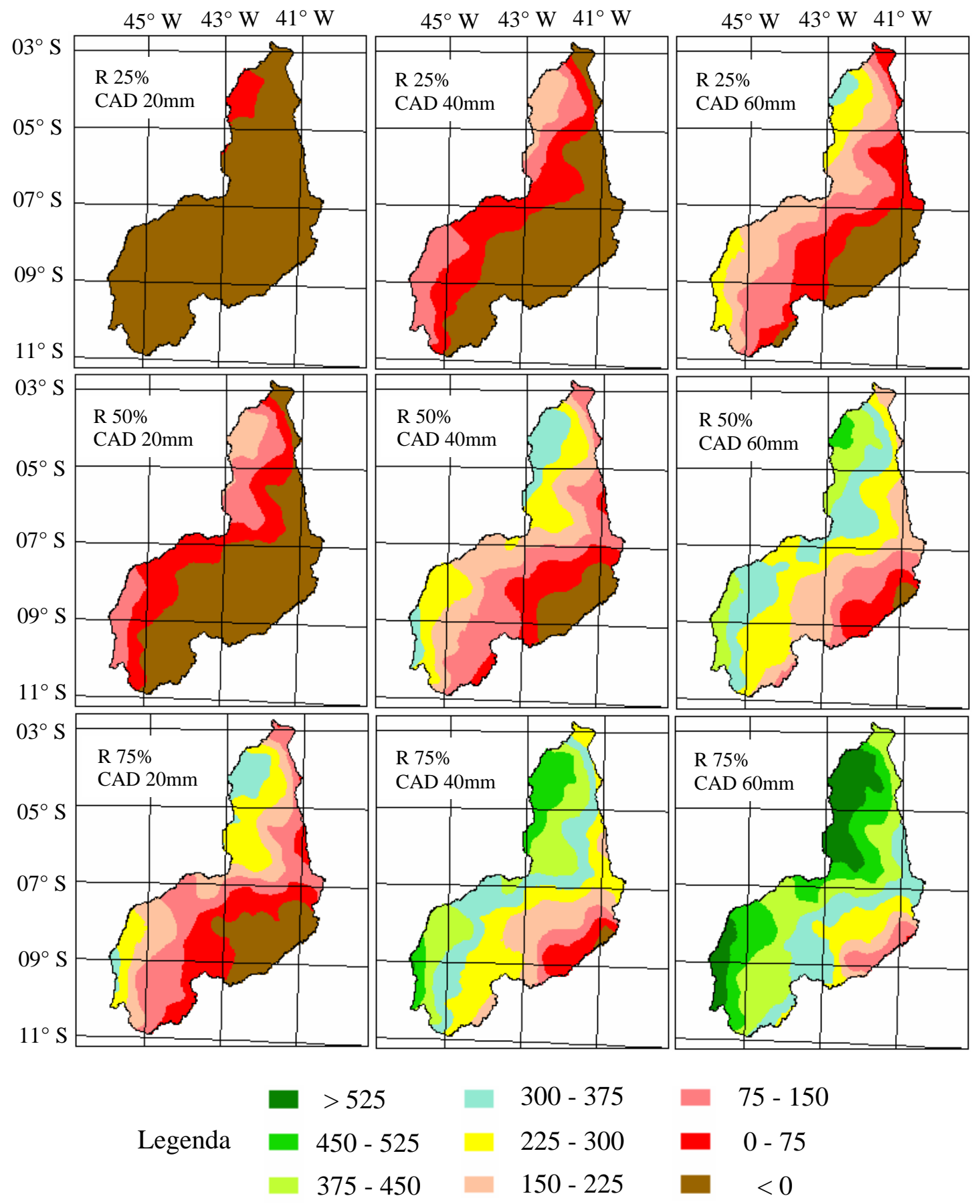

Figura 15 - Receitas líquidas (US\$ ha ${ }^{-1}$ ) obtidas com o cultivo de sequeiro do feijão-caupi no estado do Piaú, com semeadura em $1^{\circ}$ de janeiro e diferentes níveis de risco (R) e capacidade de água disponível no solo (CAD) 

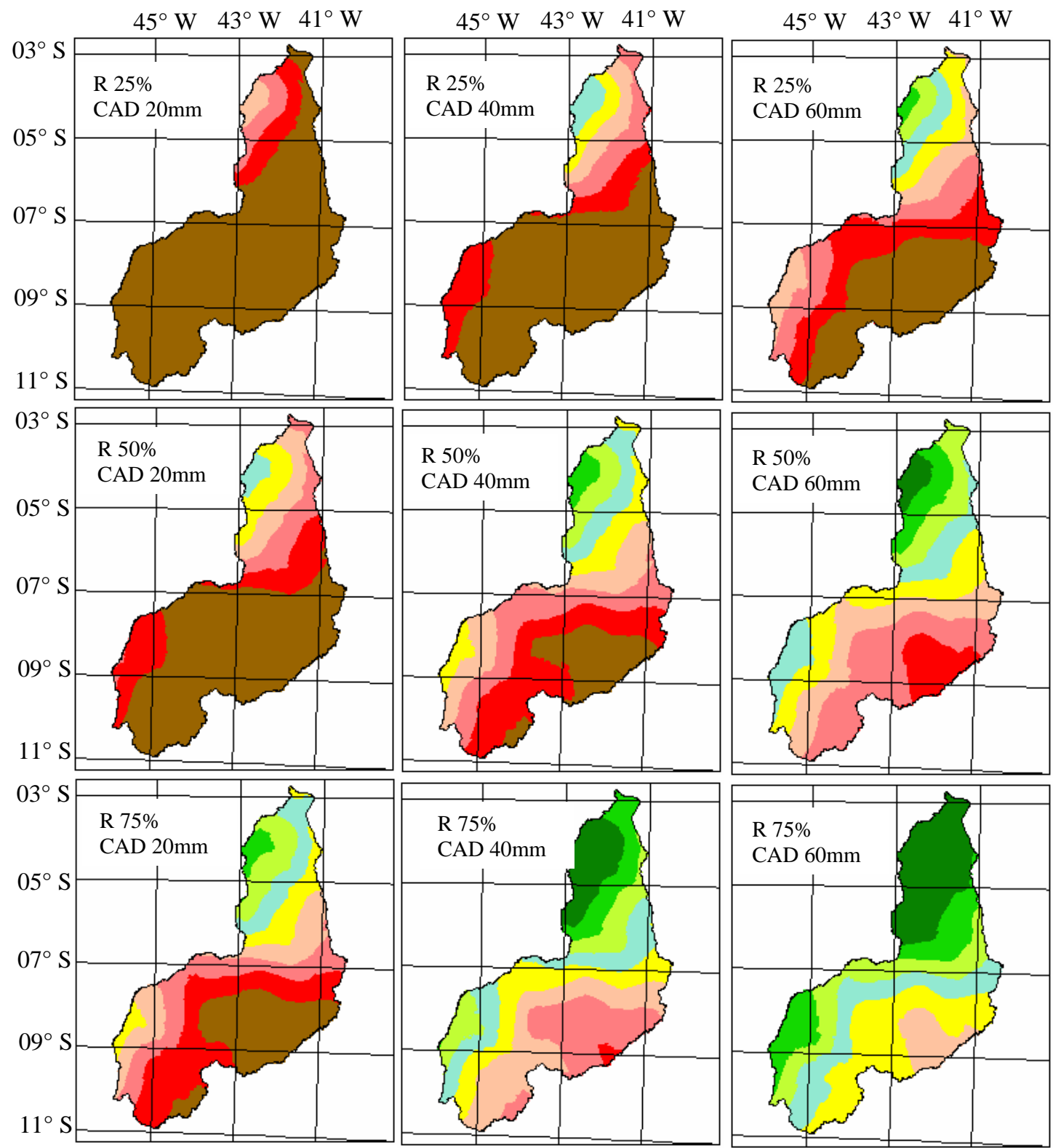

$$
\begin{aligned}
& \text { - }>525 \\
& 300-375 \\
& 75 \text { - } 150 \\
& 450 \text { - } 525 \\
& 225-300 \\
& \text { - } 0 \text { - } 75 \\
& 375 \text { - } 450 \\
& 150-225 \\
& <0
\end{aligned}
$$

Figura 16 - Receitas líquidas (US\$ ha ${ }^{-1}$ ) obtidas com o cultivo de sequeiro do feijãocaupi no estado do Piauí, com semeadura em $1^{\circ}$ de fevereiro e diferentes níveis de risco $(\mathrm{R})$ e capacidade de água disponível no solo (CAD) 


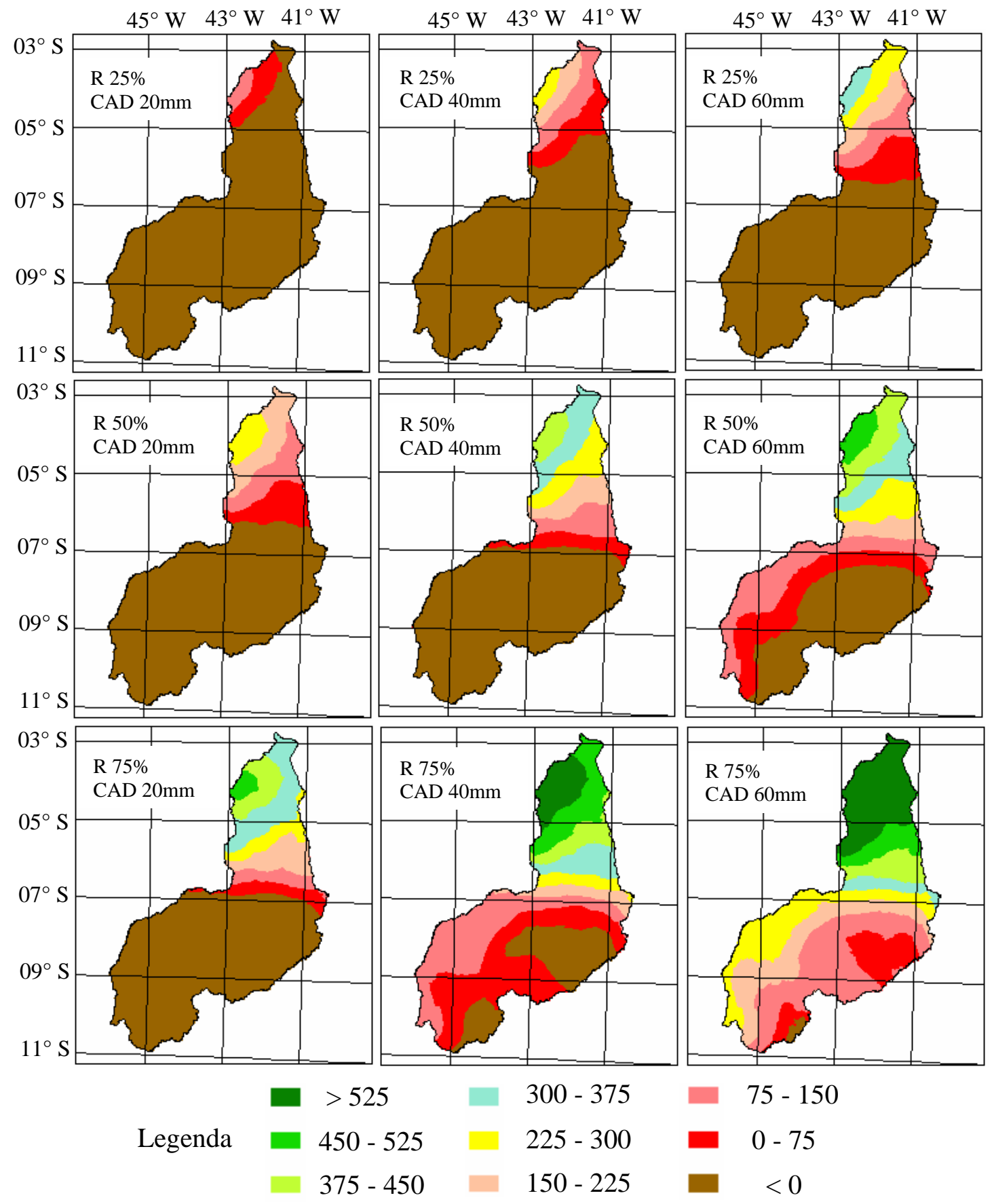

Figura 17 - Receitas líquidas (US\$ ha ${ }^{-1}$ ) obtidas com o cultivo de sequeiro do feijão-caupi no estado do Piauí, com semeadura em $1^{\circ}$ de março e diferentes níveis de risco (R) e capacidade de água disponível no solo (CAD) 

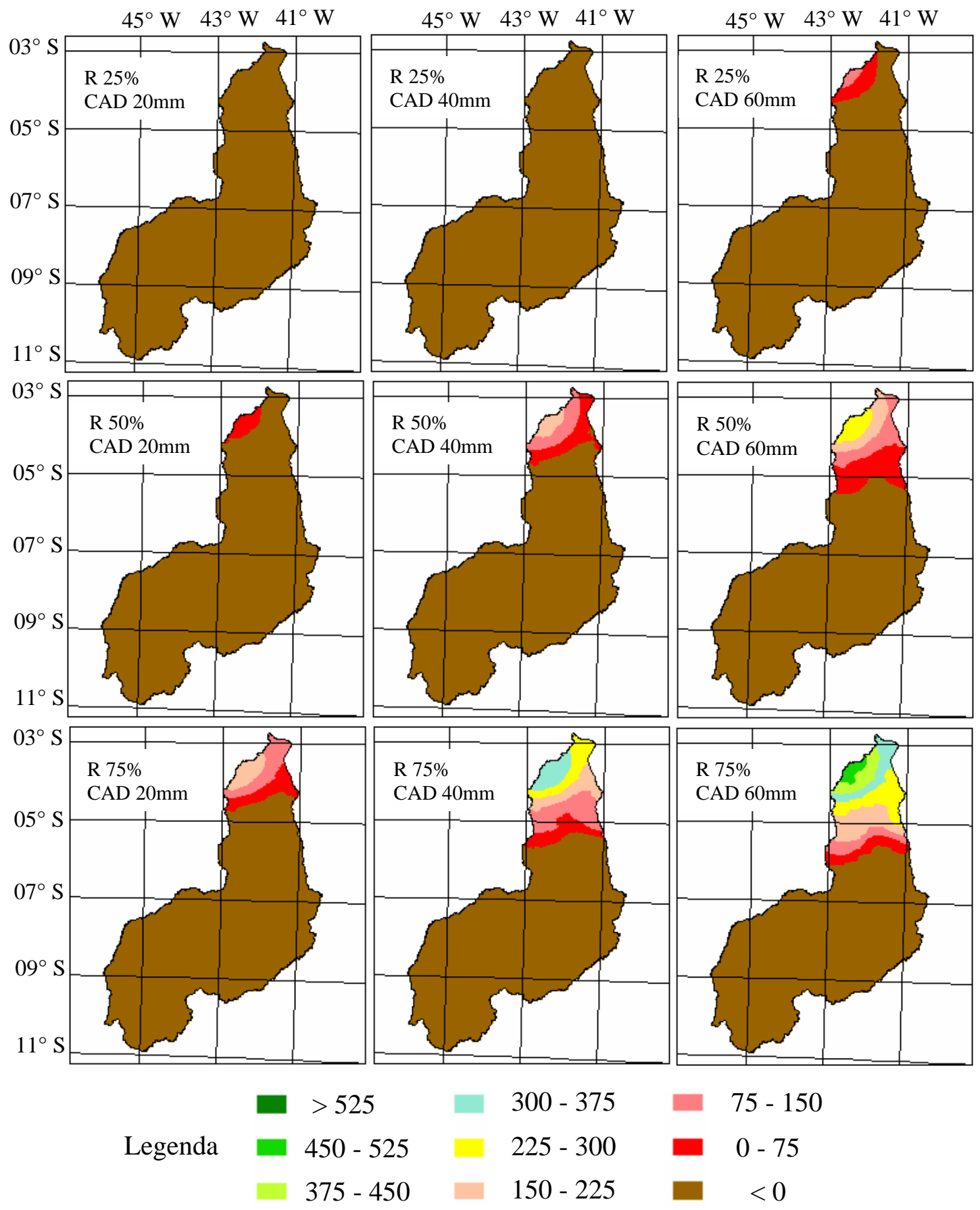

$300-375$

$75-150$

$225-300$

$0-75$

$375-450$

$150-225$

$<0$

Figura 18 - Receitas líquidas (US\$ ha ${ }^{-1}$ ) obtidas com o cultivo de sequeiro do feijão caupi no estado do Piauí, com semeadura em $1^{\circ}$ de abril e diferentes níveis de risco (R) e capacidade de água disponível no solo (CAD) 


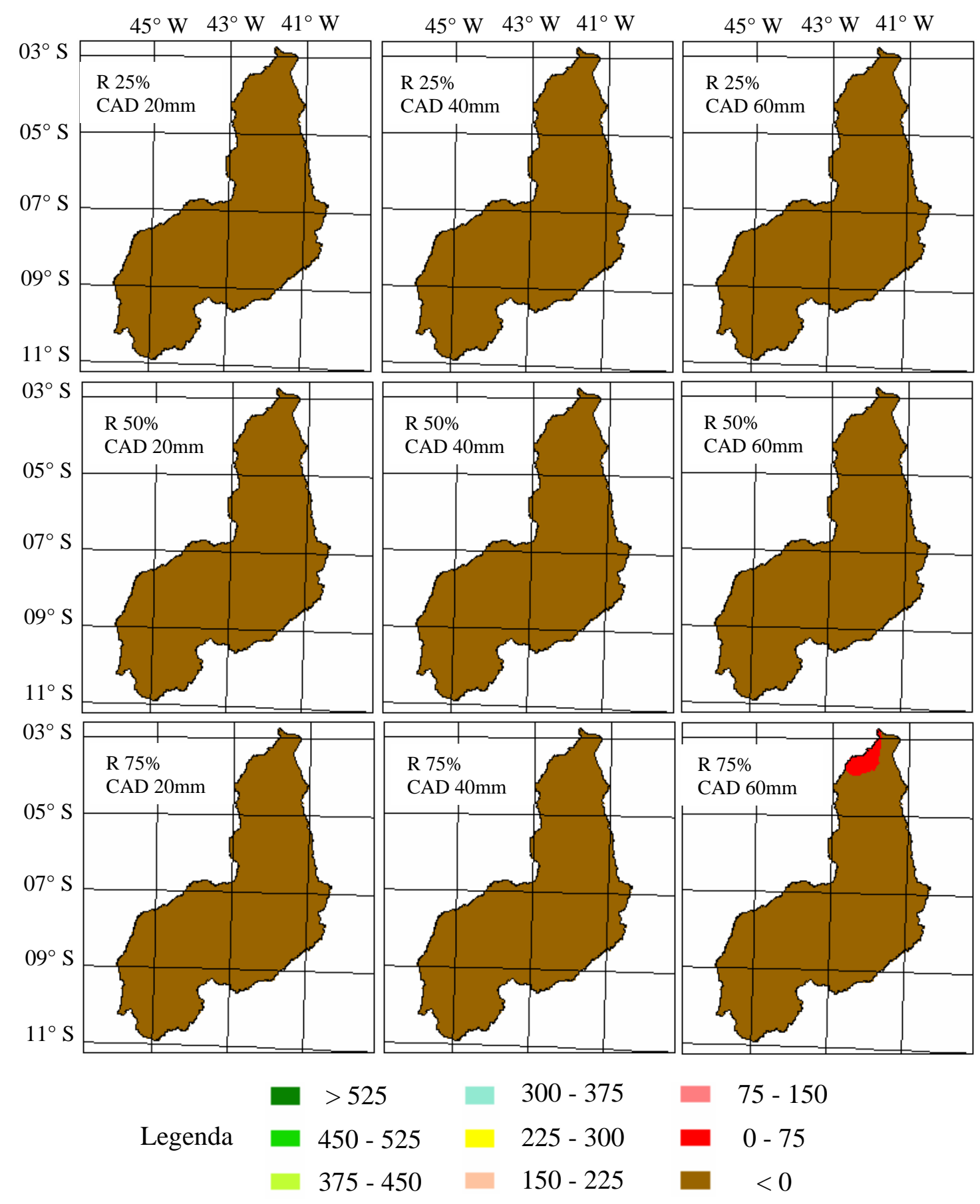

Figura 19 - Receitas líquidas (US\$ ha ${ }^{-1}$ ) obtidas com o cultivo de sequeiro do feijãocaupi no estado do Piauí, com semeadura em $1^{\circ}$ de maio e diferentes níveis de risco (R) e capacidade de água disponível no solo (CAD) 

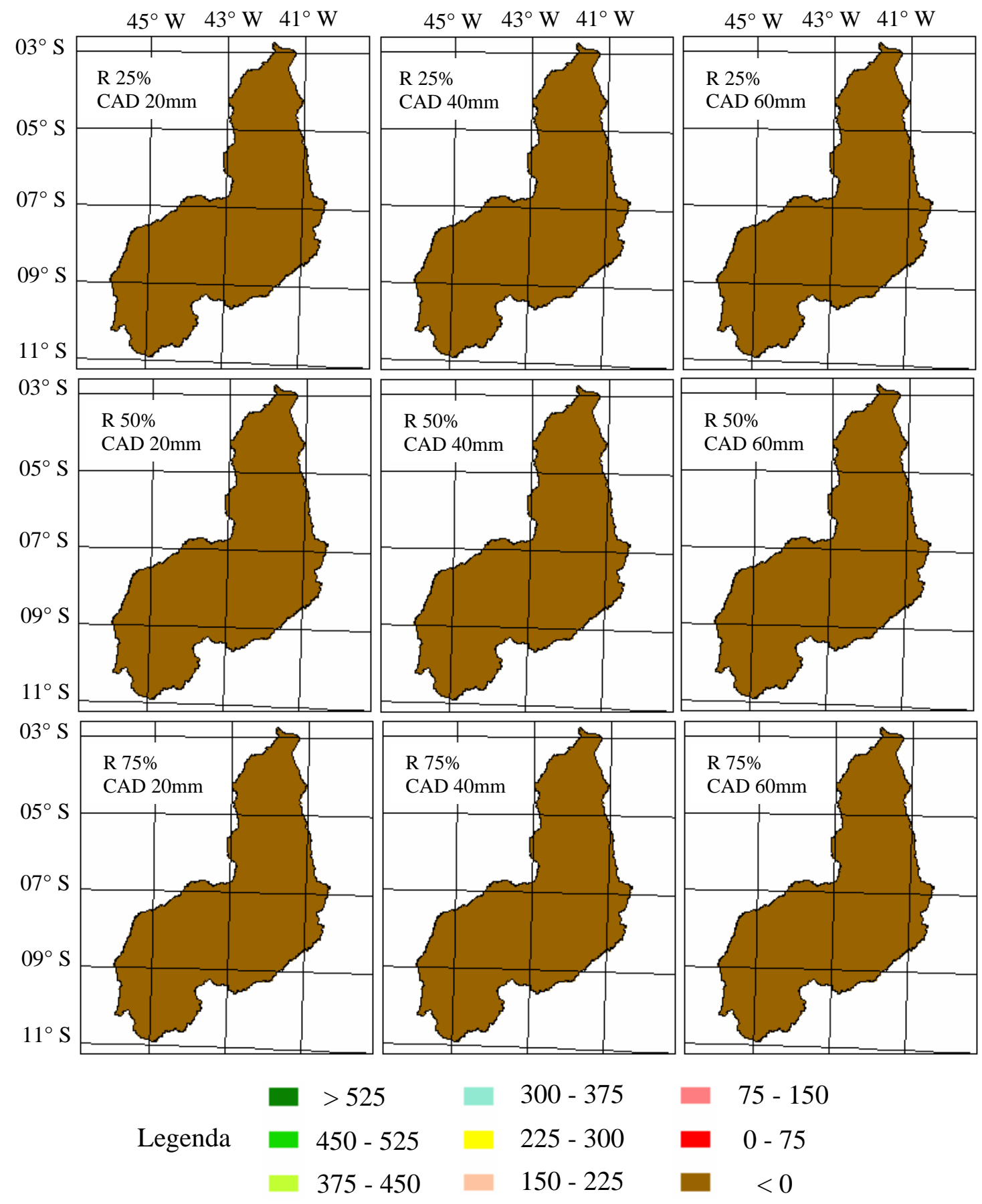

Figura 20 - Receitas líquidas (US\$ ha ${ }^{-1}$ ) obtidas com o cultivo de sequeiro do feijãocaupi no estado do Piauí, com semeadura em $1^{\circ}$ de junho e diferentes níveis de risco $(\mathrm{R})$ e capacidade de água disponível no solo (CAD) 

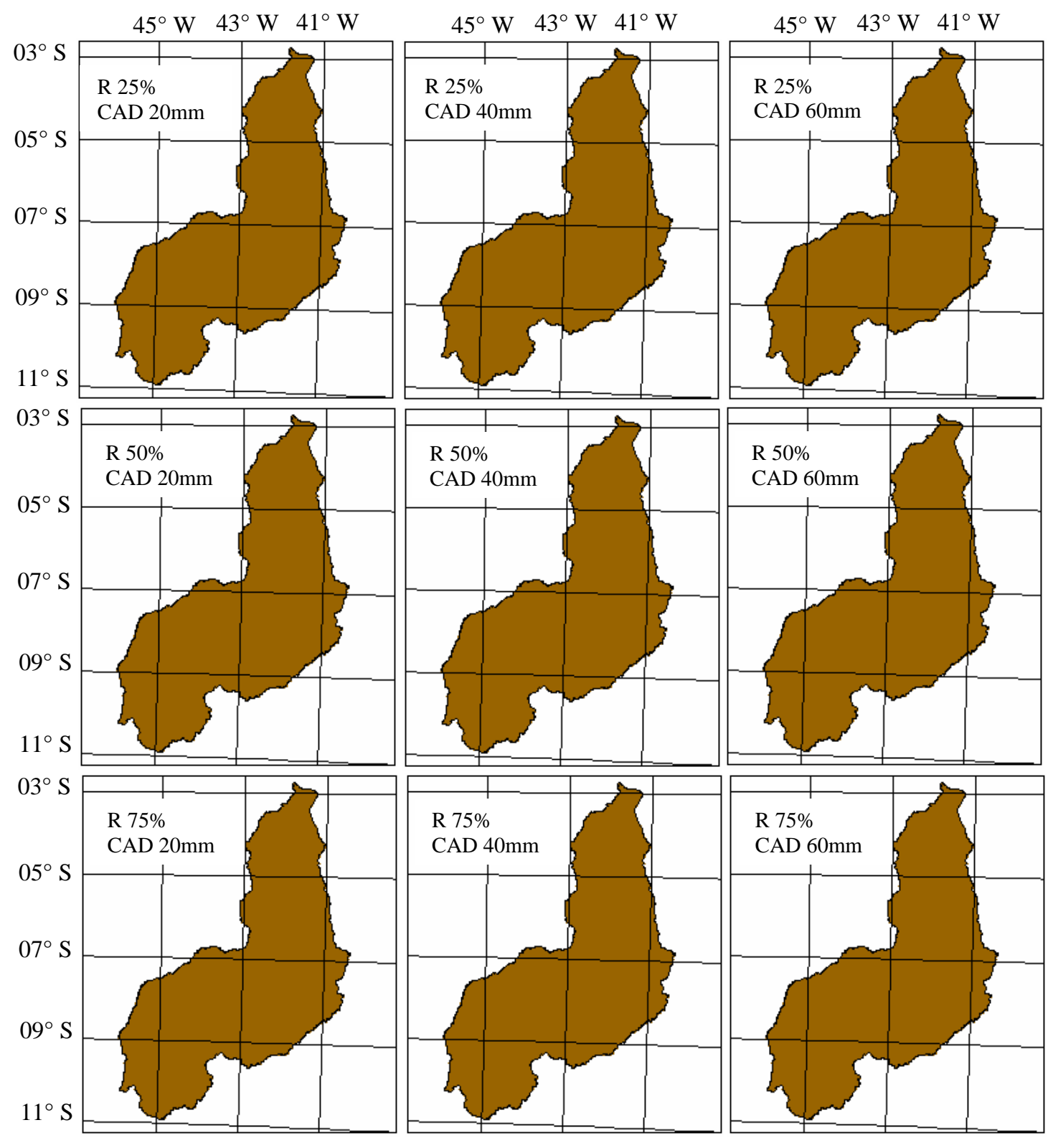

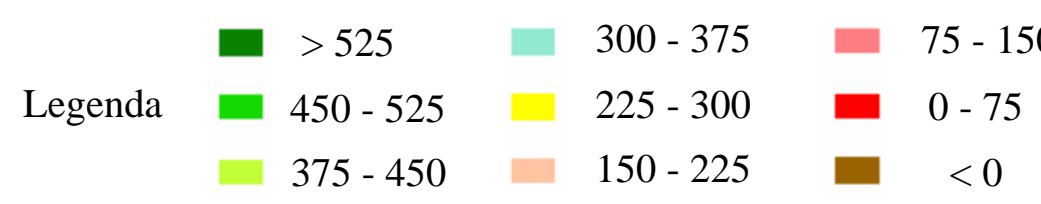

Figura 21 - Receitas líquidas (US\$ ha ${ }^{-1}$ ) obtidas com o cultivo de sequeiro do feijãocaupi no estado do Piauí, com semeadura em $1^{\circ}$ de julho e diferentes níveis de risco (R) e capacidade de água disponível no solo (CAD) 

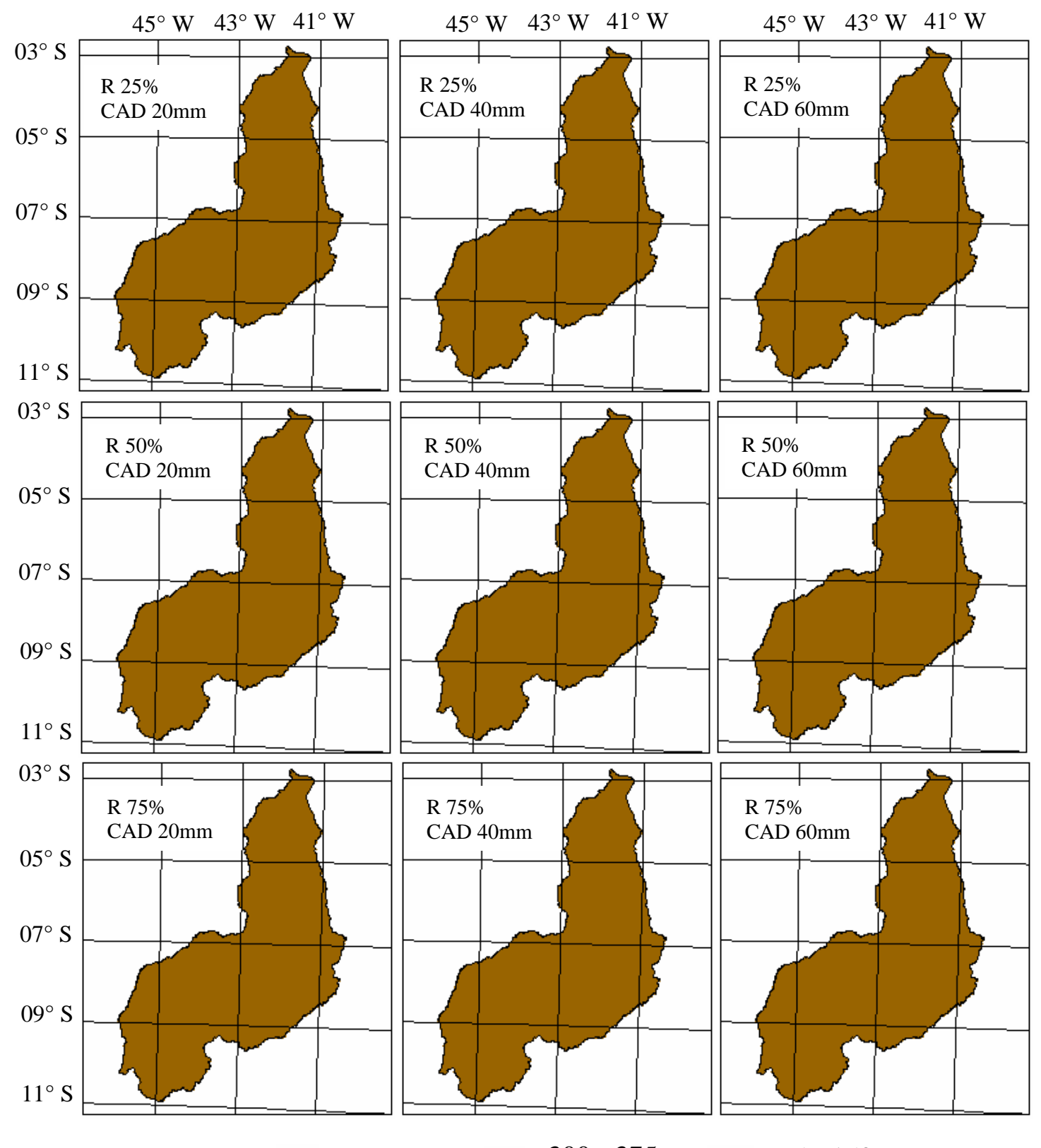

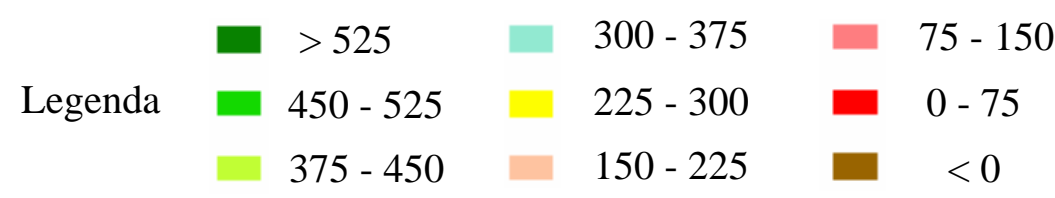

Figura 22 - Receitas líquidas (US\$ ha ${ }^{-1}$ ) obtidas com o cultivo de sequeiro do feijãocaupi no estado do Piauí, com semeadura em $1^{\circ}$ de agosto e diferentes níveis de risco (R) e capacidade de água disponível no solo (CAD) 

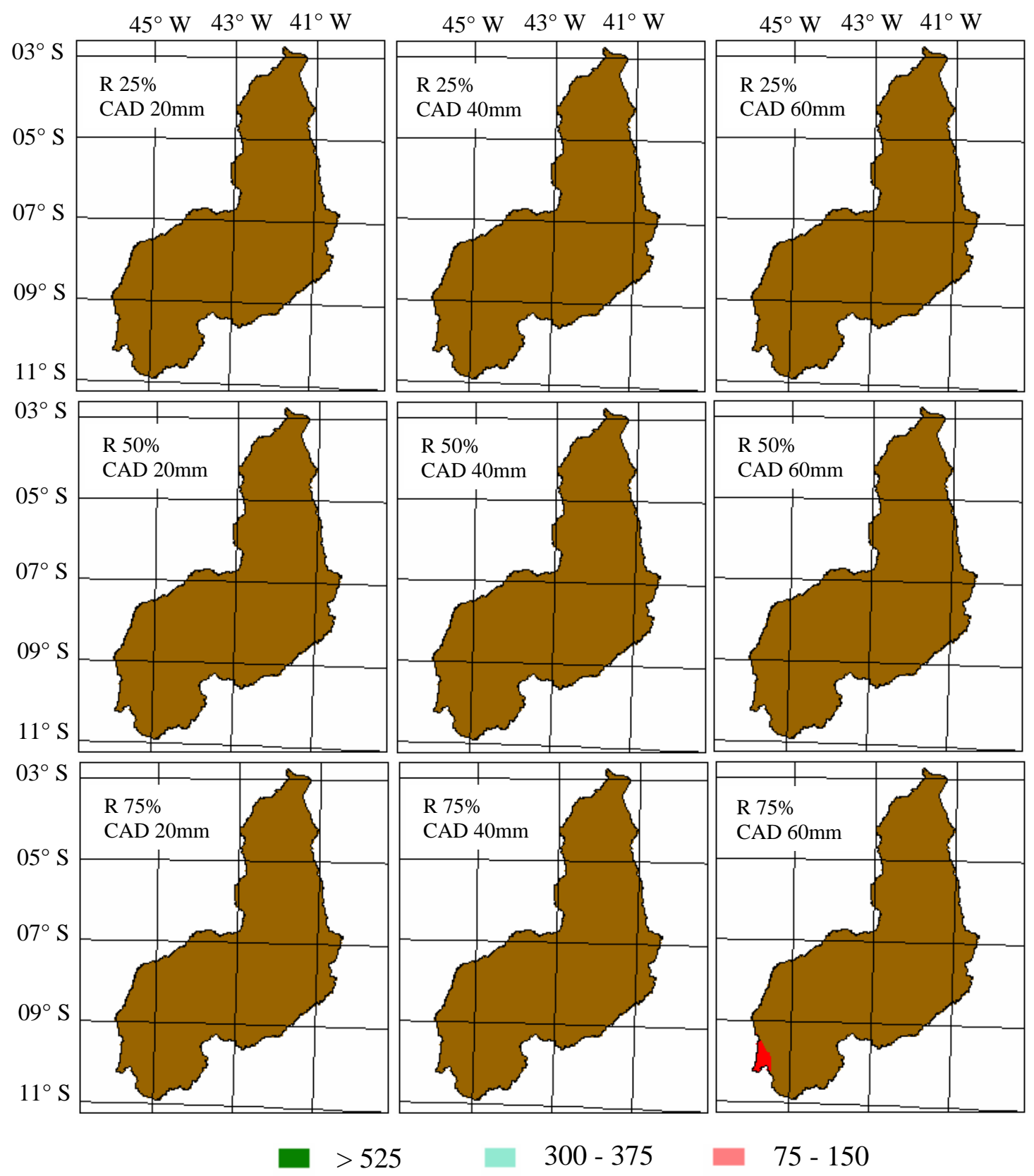

Legenda

$$
\begin{aligned}
& 450-525 \\
& 375-450
\end{aligned}
$$$$
300-375
$$$$
75-150
$$

$$
\begin{aligned}
& 225-300 \\
& 150-225
\end{aligned}
$$$$
0-75
$$$$
<0
$$

Figura 23 - Receitas líquidas (US\$ ha ${ }^{-1}$ ) obtidas com o cultivo de sequeiro do feijãocaupi no estado do Piauí, com semeadura em $1^{\circ}$ de setembro e diferentes níveis de risco (R) e capacidade de água disponível no solo (CAD) 

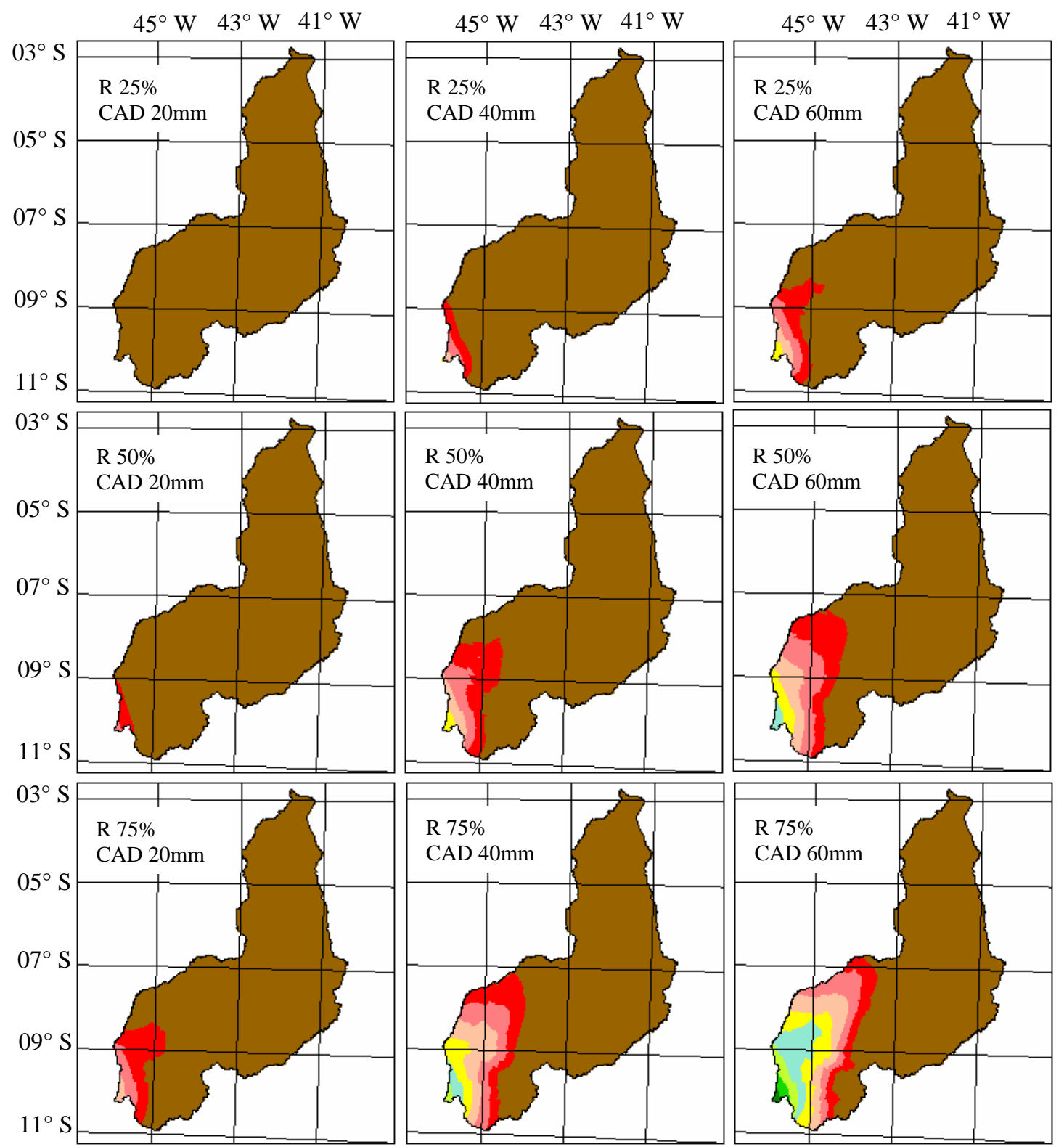

$$
\begin{aligned}
& \text { - }>525 \\
& 300-375 \\
& 75 \text { - } 150
\end{aligned}
$$

Figura 24 - Receitas líquidas (US\$ ha ${ }^{-1}$ ) obtidas com o cultivo de sequeiro do feijãocaupi no estado do Piauí, com semeadura em $1^{\circ}$ de outubro e diferentes níveis de risco (R) e capacidade de água disponível no solo (CAD) 

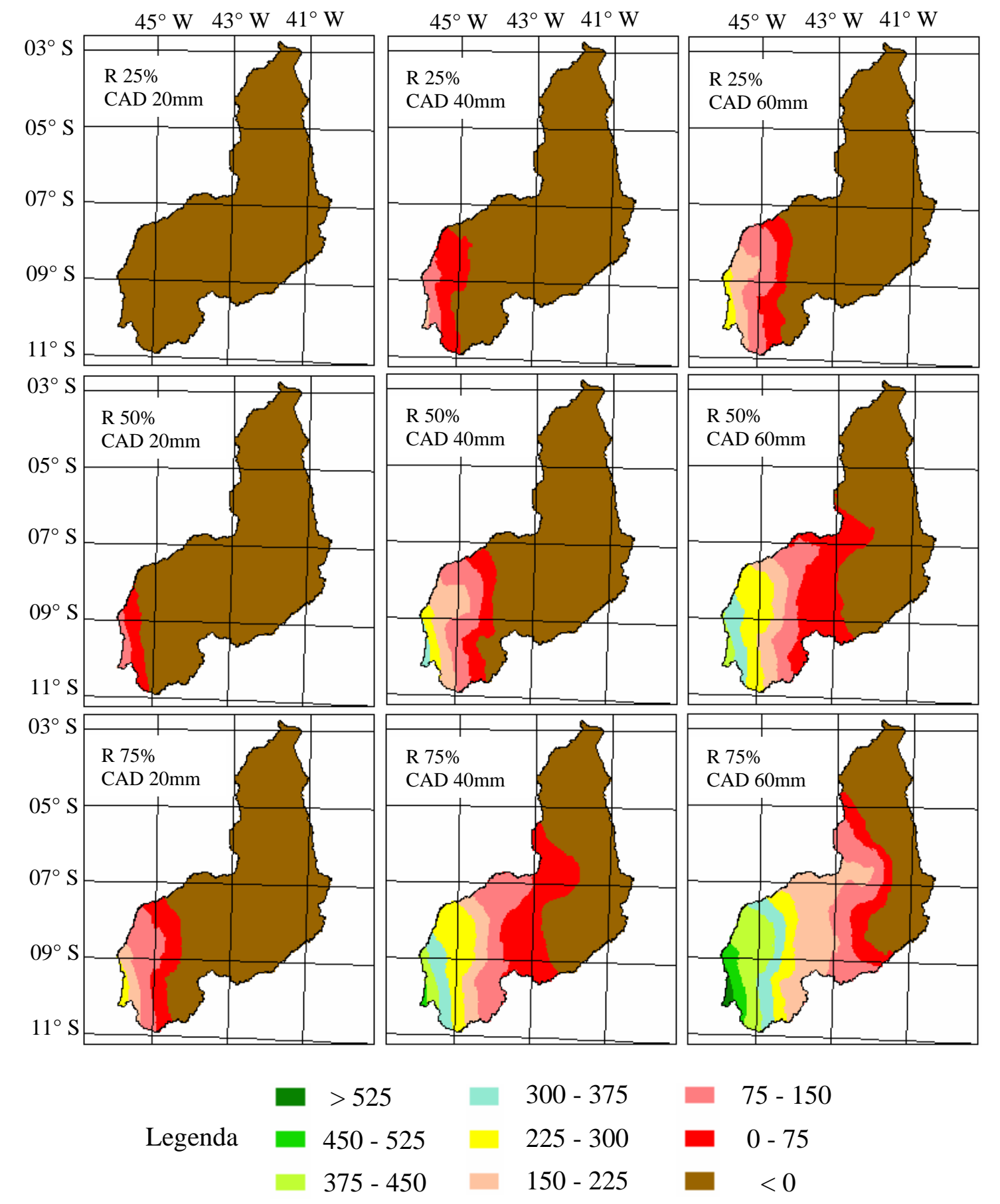

Figura 25 - Receitas líquidas (US\$ ha ${ }^{-1}$ ) obtidas com o cultivo de sequeiro do feijãocaupi no estado do Piauí, com semeadura em $1^{\circ}$ de novembro e diferentes níveis de risco (R) e capacidade de água disponível no solo (CAD) 

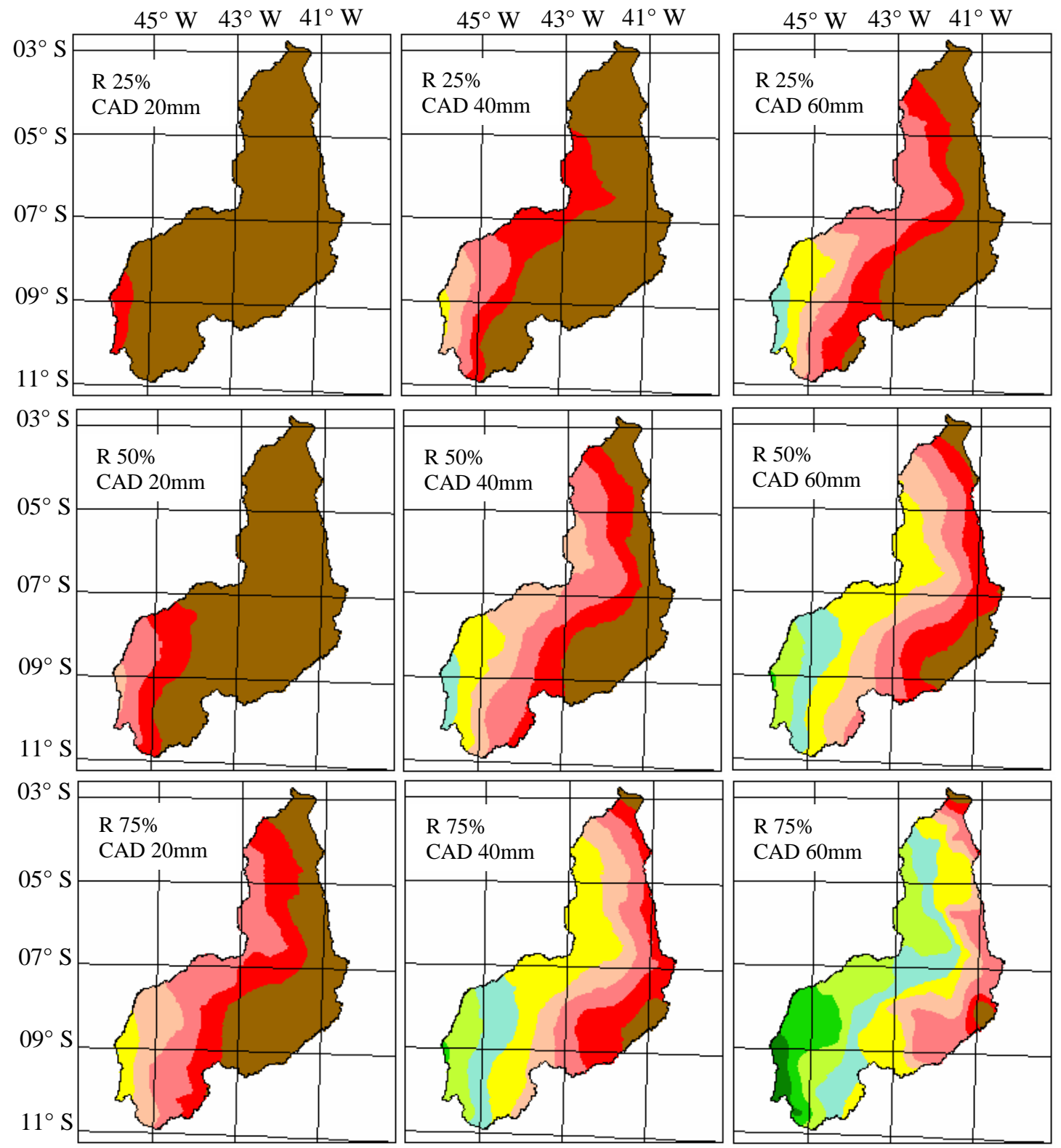

$$
\begin{array}{clll} 
& >525 & 300-375 & \\
\text { Legenda } & 45-150 \\
& 450-525 & 225-300 \\
& 375-450 & 150-225 & 0-75 \\
& 375 & <0
\end{array}
$$

Figura 26 - Receitas líquidas (US\$ ha ${ }^{-1}$ ) obtidas com o cultivo de sequeiro do feijãocaupi no estado do Piauí, com semeadura em $1^{\circ}$ de dezembro e diferentes níveis de risco $(\mathrm{R})$ e capacidade de água disponível no solo (CAD) 


\section{REFERÊNCIAS BIBLIOGRÁFICAS}

ALGOZIN, K.A.; BRALTS, V.F.; RITCHIE, J.T. Irrigation strategy selection based on crop yield, water and energy use relationships: A Michigan example. Journal of Soil and Water Conservation, v.43, p.428-431, Sep-Oct. 1988.

ANDRADE, M.J.B. Clima e solo. In: VIEIRA, C.; PAULA JÚNIOR, T. J.; BORÉM, A. (Ed.). Feijão: aspectos gerais e cultura no estado de Minas Gerais. Viçosa: UFV, 1998. 596p

ANDRADE, C.L.T.; SILVA, A.A.G.; SOUZA, I.R.P.; CONCEIÇÃO, M.A.F. Coeficientes de cultivo e de irrigação para o caupi. Teresina: Embrapa, CNPAI, 1993. 6p. (Embrapa. CNPAI. Comunicado Técnico, 9).

ANDRADE JÚNIOR, A.S. de. Viabilidade da irrigação, sob risco climático e econômico, nas microrregiões de Teresina e Litoral Piauiense. Piracicaba, 2000. 566p. Tese (Doutorado)- Escola Superior de Agricultura "Luiz de Queiroz", Universidade de São Paulo.

ANDRADE JÚNIOR, A.S. de; MELO, F.B.; BASTOS, E. A. Zoneamento de risco climático para o feijão-caupi no Piauí. In: REUNIÃO NACIONAL DE PESQUISA DE CAUPI, 5., Teresina, 2001. Anais. Teresina: Embrapa Meio-Norte, 2001. p.3-7. (Embrapa Meio-Norte, Documentos, 56). 
ANDRADE JÚNIOR, A.S. de; RODRIGUES, B.H.N.; FRIZZONE, J.A.; CARDOSO, M.J.; BASTOS, E.A.; MELO, F.B. Níveis de irrigação na cultura do feijão caupi. Revista Brasileira de Engenharia Agrícola e Ambiental, v.6, n.1, p.17-20, 2002.

ASSAD, E.D.; SANO, E.E.; BEZERRA, H.S.; SILVA, S.C.; LOBATO, E.J.E. Uso de modelos numéricos de terreno na espacialização de épocas de plantio. In: ASSAD, E.D.; SANO, E.E. (Ed.). Sistemas de informações geográficas: aplicações na agricultura. Brasília: Embrapa SPI;Embrapa CPAC, 1998. cap.16, p.311-326.

AZEVEDO FILHO, A.J.B.V. Análise econômica de projetos: "Software" para situações deterministas e de risco envolvendo simulação. Piracicaba, 1988. 127p. Tese (Doutorado) - Escola Superior de Agricultura "Luiz de Queiroz", Universidade de São Paulo.

BARROS, V.S.; COSTA, R.N.T.; MEDEIROS, A.T.; OLIVEIRA, V.R. Análise de componentes do balanço hídrico em cultura de feijão-de-corda sob condições de recarga natural. In: CONGRESSO BRASILEIRO DE ENGENHARIA AGRÍCOLA, 27., Poços de Caldas, 1998. Anais. Poços de Caldas: SBEA; UFLA, 1998. v.1, p.247-249.

BASTOS, E.A.; FOLEGATTI, M.V.; ANDRADE JÚNIOR, A.S. de; CARDOSO, M.J.; FARIA, R.T. Manejo econômico da irrigação de feijão caupi via modelo de simulação. Irriga, v.5, n.2, p.84-98, 2000.

BASTOS, E.A.; RODRIGUES, B.H.N.; ANDRADE ÚNIOR, A.S. de; CARDOSO, M.J. Parâmetros de crescimento do feijão caupi sob diferentes regimes hídricos. Engenharia Agrícola, v.22, n.1, p.43-50, 2002.

BERNARDO, S. Manual de irrigação. 5.ed. Viçosa: UFV, Imprensa Universitária, 1989. 586p. 
BEZERRA, J.R.C.; FREIRE FILHO, F.R. Evapotranspiração da cultura do feijão macassar (Vigna unguiculata L. Walp.) no município de Teresina - Piauí. In: SEMINÁRIO DE PESQUISA AGROPECUÁRIA DO PIAUÍ, 3., Teresina, 1982. Anais. Teresina: Embrapa, UEPAE de Teresina, 1984. p.304-324.

BEZERRA, F.M.L.; OLIVEIRA, C.H.C. Evapotranspiração real do caupi (Vigna unguiculata L. Walp.) no período chuvoso em Fortaleza - CE. In: CONGRESSO BRASILEIRO DE ENGENHARIA AGRÍCOLA, 27., Poços de Caldas, 1998. Anais. Poços de Caldas: SBEA; UFLA, 1998. v.2, p.85-87.

BEZERRA, F.M.L.; SAUNDERS, L.C.U. Irrigação de dois cultivares de feijão-decorda (Vigna unguiculata (L.) Walp.) em três épocas de plantio sob dois níveis de irrigação no Vale do Curu. Ciência Agronômica, v.23, n.1/2, p.39-44, 1992.

BEZERRA, F.M.L.; ARARIPE, M.A.E.; OLIVEIRA, C.H.C. Coeficientes de cultura de três cultivares de caupi em Fortaleza, CE (compact disc). In: CONGRESSO BRASILEIRO DE ENGENHARIA AGRÍCOLA, 28., Pelotas, 1999. Anais. Pelotas: SBEA; UFPel, 1999.

BISERRA, J.V. Rentabilidade da irrigação pública do Nordeste, sob condições de risco o caso do perímetro Morada Nova. Revista de Economia e Sociologia Rural, v.32, n.3, p.289-303, 1994.

BOGGES, W.G.; RITCHIE, J.T. Economic and risk analysis of irrigation decisions in humid regions. Journal of Production Agriculture, v.1, n.2, p.116-122, 1988.

BRUNELLI, G.M. Simulação do custo de produção de laranja no estado de São Paulo. Piracicaba, 1990. 99p. Dissertação (Mestrado) - Escola Superior de Agricultura "Luiz de Queiroz", Universidade de São Paulo. 
BURROUGH, P.A.; McDONNEL, R.A. Principles of geographical information system. New York: Oxford University Press, 1998. 333p.

CALHEIROS, C.B.M.; QUEIROZ, J.E. FRIZZONE, J.A.; PESSOA, P.C.S. Estratégias ótimas de irrigação do feijoeiro: água como fator limitante da produção. Pesquisa Agropecuária Brasileira, v.31, n.7, p.509-515, 1996.

CÂMARA, G.; SOUZA, R.C.M.; FREITAS, U.M.; GARRIDO, J. SPRING: Integrating remote sensing and GIS by object-oriented data modelling. Computers \& Graphics, v.20, n.3, p.395-403, 1996.

CARDOSO, C.O. Análise de riscos climáticos e estratégias de irrigação para milho "safrinha" no Paraná, através de modelos de simulação. Piracicaba, 2001. 114p. Tese (Doutorado) - Escola Superior de Agricultura "Luiz de Queiroz", Universidade de São Paulo.

CARDOSO, C.O.; FARIA, R.T.; FOLEGATTI, M.V. Simulação do rendimento e riscos climáticos para o milho safrinha em Londrina-Pr. Engenharia Agrícola, v.24, n.2, p.291-300, 2004.

CARDOSO, M.J.; FREIRE FILHO, F.R.; BEZERRA, J.R.C. Comportamento produtivo de genótipos de feijão macassar sob regime de irrigação. Ciência Agronômica, v.18, p.63-66, 1987.

CARDOSO, M.J.; FREIRE FILHO, F.R.; ATHAYDE SOBRINHO, C. Cultura do feijão macassar (Vigna unguiculata (L.) Walp.) no Piauí: aspectos técnicos. Teresina: EMBRAPA, UEPAE de Teresina, 1991. 43p. (EMBRAPA. UEPAE de Teresina. Circular Técnica, 9). 
CARDOSO, M.J.; MELO, F.B.; ANDRADE JÚNIOR, A.S. de. Densidade de plantas de caupi em regime irrigado. Pesquisa Agropecuária Brasileira, v.32, n.4, p.399-405, 1997.

CARDOSO, M.J.; ANDRADE JÚNIOR, A.S. de; MELO, F.B.; FROTA, A.B. Avaliação agroeconômica da produção de sementes de caupi sob irrigação. Teresina: Embrapa, CPAMN, 1995. 6p. (Embrapa. CPAMN. Comunicado Técnico, $62)$.

CARVALHO, J.A; PEREIRA, G.M.; ANDRADE, M.J.B.; ROQUE, M.W. Efeito do déficit hídrico sobre o rendimento do Feijão Caupi (Vigna unguiculata (L.) Walp). Ciência e Agrotecnologia, v.24, n.3, p.710-717, 2000.

CORDEIRO, L.G. Influência do déficit hídrico em diferentes estágios fenológicos sobre a produção de feijão caupi (Vigna unguiculata (L.) Walp.). Fortaleza, 1998. 58p. Dissertação (M. S.) - Universidade Federal do Ceará.

CORDEIRO, L.G.; BEZERRA, F.M.L.; SANTOS, J.J.A.; MIRANDA, E.P. Fator de sensibilidade ao déficit hídrico (Ky) da cultura do feijão caupi (Vigna unguiculata L. Walp.). In: CONGRESSO BRASILEIRO DE ENGENHARIA AGRÍCOLA, 27., Poços de Caldas, 1998. Anais. Poços de Caldas: SBEA; UFLA, 1998. v.2, p.178180.

COSTA, M.M.M.N.; TÁVORA, J.A.F.; PINHO, J.L.N.; MELO, F.I.O. Produção, componentes de produção, crescimento e distribuição das raízes de caupi submetido à deficiência hídrica. Pesquisa Agropecuária Brasileira, v.32, n.1, p.43-50, 1997.

CRUZ, J.M. Cultivares eretas e decumbentes de Caupi (Vigna unguiculata L. Walp.) submetidas a diferentes níveis de disponibilidade hídrica no solo. Fortaleza, 1993. 119p. Dissertação (M. S.) - Universidade Federal do Ceará. 
CUNHA, G.R.; BERGAMASCHI, H. Efeitos da disponibilidade hídrica sobre o rendimento das culturas. In: BERGAMASCHI, H. (Coord.). Agrometeorologia aplicada à irrigação. 2.ed. Porto Alegre: Editora Universidade/UFRGS, 1999. cap. 6, p. 85-97.

DIAS, C.T.S. Planejamento de uma fazenda em condições de risco: programação linear e simulação multidimensional. Piracicaba, 1996. 100p. Tese (Doutorado) - Escola Superior de Agricultura "Luiz de Queiroz", Universidade de São Paulo.

DOORENBOS, J.; KASSAM, A.H. Efeito da água no rendimento das culturas. Trad. de H.R. Gheyi et al. 2.ed. Campina Grande: UFPB, 2000. 221p. (Estudos FAO: Irrigação e Drenagem, 33).

DOORENBOS, J.; PRUITT, W.O. Necessidades hídrica das culturas. Trad. de H.R. Gheyi et al. Campina Grande: UFPB, 1997. (Estudos FAO: Irrigação e Drenagem, 24).

EMPRESA BRASILEIRA DE PESQUISA AGROPECUÁRIA. Cultivo de feijão caupi, Teresina, 2003a. Embrapa Meio-Norte. Sistemas de produção, 2. Versão eletrônica.

EMPRESA BRASILEIRA DE PESQUISA AGROPECUÁRIA. Sistema de Produção de Citrus para o Nordeste. 2003b. EMBRAPA Mandioca e Fruticultura. Sistemas de produção, 16. Versão eletrônica.

EMPRESA BRASILEIRA DE PESQUISA AGROPECUÁRIA. Centro Nacional de Pesquisa de Solos. Sistema Brasileiro de Classificação de Solos. Brasília: Embrapa Produção da Informação; Rio de Janeiro: Embrapa Solos, 1999. 412p. 
FANCELLI, A.L.; DOURADO NETO, D. Estresse de água e temperatura na cultura de feijão. In: FANCELLI, A. L.; DOURADO NETO, D. Feijão irrigado: estratégias básicas de manejo. Piracicaba: Publique, 1999. p.155-169.

FAO. Faostat Agriculture. 2004. http://faostat.fao.org/faostat/. (16 maio 2004)

FARIA, R.A.; SOARES, A.A.; SEDIYAMA, G.C; RIBEIRO, C.A.A.S. Demanda de irrigação suplementar para a cultura do milho no estado de Minas Gerais. Revista Brasileira de Engenharia Agrícola e Ambiental, v.4, n.1, p.46-50, 2000.

FARIAS, J.R.B.; ASSAD, E.D.; ALMEIDA, I.R. DE; EVANGELISTA, B.A.; SILVA, F.A.M DA; BEZERRA, H.S.; LAZZAROTTO, C. Identificação de regiões com riscos de déficit hídrico à cultura da soja. In: CONGRESSO BRASILEIRO DE AGrometeorologiA, 10., Piracicaba, 1997. Anais. Piracicaba: Sociedade Brasileira de Agrometeorologia, 1997. p.345-347.

FELGUEIRAS, C. Modelagem ambiental com tratamento de incertezas em Sistemas de Informação Geográfica: o paradigma geoestatístico por indicação. Instituto Nacional de Pesquisas Espaciais, 2000. http://www.dpi.inpe.br/teses/carlos. (20 nov. 2004.

FNP CONSULTORIA \& COMÉRCIO. Agrianual 2004: anuário da agricultura brasileira. São Paulo. 2004. 546p.

FOLLEGATTI, M.V.; PAZ, V.P.S.; PEREIRA, A.S.; LIBARDI, V.C.M. Efeitos de diferentes níveis de irrigação e do déficit hídrico na produção do feijoeiro (Phaseolus vulgaris L.). In: CONGRESO CHILENO DE INGENIERIA AGRÍCOLA, 2., Resumenes de trabajos. Chillan : Universidad de Concepcion, 1997. p.73. 
FONTANA, D.C.; BERLATO, M.A.; BERGAMASCHI, H. Alterações micrometeorológicas na cultura da soja submetida a diferentes regimes hídricos. Pesquisa Agropecuária Brasileira, v.27, n.5, p.661-669, 1992.

FRANCISCO, W. Matemática financeira. 7.ed. São Paulo: Atlas, 1991. 319p.

FRANKE, A.E. Balanço hídrico na cultura da batata (Solanum tuberosum L.) sob três níveis de manejo da irrigação. Santa Maria, 1990. 92p. Dissertação (M.S.) Universidade Federal de Santa Maria.

FRANKE, A.E. Avaliação econômica da irrigação, sob condições de risco, nas condições edafoclimáticas do Planalto Médio e Missões, RS. Porto Alegre, 1996. 116p. Tese (Doutorado) - Instituto de Pesquisas Hidráulicas, Universidade Federal do Rio Grande do Sul.

FRANKE, A.E.; DORFMAN, R. Viabilidade econômica da irrigação, sob condições de risco, em regiões de clima subtropical. I Cultura do milho. Pesquisa Agropecuária Brasileira, v.33, n.12, p.2003-2013, 1998.

FRIZZONE, J.A. Função de produção. In: FARIA, M.A.; SILVA, E.L.; VILELA, L.A.A.; SILVA, A.M. (Ed.). Manejo de irrigação. Lavras: UFLA;SBEA, 1998. p.86-116.

FRIZZONE, J.A. Análise de decisão econômica em irrigação. Piracicaba: ESALQ,LER, 2005. 371p. (Série Didática, 17).

FRIZZONE, J.A; SILVEIRA, S.F.R. Análise econômica de projetos hidroagrícolas. In: SILVA, D.D.; PRUSKI, F.F. (Ed.). Gestão de recursos hídricos: aspectos legais, econômicos, administrativos e sociais. Brasília: SRH; Viçosa: UFV; Porto Alegre: ABRH, 2000. cap. 5, p.449-617. 
GENNEVILLE, M.S.; BOOCK, A. Modelo estocástico para simulação da precipitação pluviométrica diária de uma região. Pesquisa Agropecuária Brasileira, v.18, n.9, p.959-966, 1983.

GONÇALVES, A.C.A. Variabilidade espacial de propriedades físicas do solo para fins de manejo da irrigação. Piracicaba, 1997. 118p. Tese (Doutorado) - Escola Superior de Agricultura “Luiz de Queiroz”, Universidade de São Paulo.

GONÇALVES, A.C.A., FOLEGATTI, M.V.; MATA, J.D.V.. Análises exploratória e geoestatística da variabilidade de propriedades físicas de um Argissolo vermelho. Acta Scientiarum, v.3, n. 5, p.1149-1157, 2001.

GONÇALVES, S.L.; CARAMORI, P.H.; WREGE, M.S.; BRUNETTA, D; DOTTO. S. Regionalização para épocas de semeadura de trigo no estado do Paraná. Revista Brasileira de Agrometeorologia, v.6, n.2, p.239-248, 1998.

GONDIM, R.S.; AGUIAR, J.V. de; COSTA, R.N.T. Estratégias de manejo de água em caupi irrigado. Revista Brasileira de Engenharia Agrícola e Ambiental, v.4, n.1, p.14-18, 2000.

GUERRA. A.F.; SILVA, D.B. da; RODRIGUES, G.C. Manejo de irrigação e fertilização nitrogenada para o feijoeiro na região dos cerrados. Pesquisa Agropecuária Brasileira, v.35, n.6, p.1229-1236, 2000.

GUIMARÃES, C.M.; STONE, L.F.; BRUNINI, O. Adaptação do feijoeiro (Phaseolus vulgaris L.) à seca. II. Produtividade e componentes agronômicos. Pesquisa Agropecuária Brasileira, v.31, n.7, p.481-488, 1996. 
HAMLETT, J.M.; HORTON, R.; CRESSIE, A.C. Resistant and exploratory techniques for use in semivariogram analyses. Soil Science Society of America Journal, v.50, p.868-875, 1986.

HEINEMANN, A.B; HOOGENBOOM, G. Regional irrigation requirements for dry bean based on the simulation model CROPGRO and a geographic information system. Annual Report of the Bean Improvement Cooperative, v.44, p.41-42, 2001.

INSTITUTO BRASILEIRO DE GEOGRAFIA E ESTATÍSTICA. Sistema IBGE de Recuperação Automática - SIDRA: banco de dados agregados. Produção agrícola municipal. 2002. http://www.sidra.ibge.gov.br/bda/. ( 26 mar. 2004).

JOURNEL, A.G. Fundamentals of geostatistics in five lessons. Washington: American Geophysical Union, 1989. 40p.

LEITE, M.L.; RODRIGUES, J.D.; MISCHAN, M.M.; VIRGENS FILHO, J.S. Efeitos do déficit hídrico sobre a cultura do caupi (Vigna unguiculata L. Walp.), cv, EMAPA821.II - Análise de crescimento. Revista de Agricultura, v.74, n.3, p.351-370, 1999.

LIBARDI, V.C. de. Efeitos de diferentes níveis de irrigação e do déficit hídrico na produção do feijoeiro. Piracicaba, 1996. 49p. Dissertação (Mestrado) - Escola Superior de Agricultura “Luiz de Queiroz”, Universidade de São Paulo.

LIMA, G.P.B. Crescimento e produtividade do caupi (Vigna unguiculata (L.) Walp.) sob diferentes níveis de disponibilidade hídrica no solo. In: REUNIÃO NACIONAL DE PESQUISA DE CAUPI, 4., Teresina, 1996. Resumos. Teresina: EMBRAPA, CPAMN, 1996. p. 41-43. (EMBRAPA. CPAMN. Documentos, 18 ).

LIMA, M.G.; RIBEIRO, V.Q. Equações de estimativa da temperatura do ar para o estado do Piauí. Revista Brasileira de Agrometeorologia, v.6, n.2, p.221-227, 1998. 
LIMA, M.G.; SILVA, F.A.M. Evapotranspiração máxima (ETm) da cultura do feijão macassar (Vigna unguiculata (L.) Walp.). In: SEMINÁRIO DE PESQUISA AGROPECUÁRIA DO PIAUÍ, 5., Teresina, 1988. Anais. Teresina: Embrapa, UEPAE de Teresina, 1988. p.9-20.

MALUF, J.R.T.; CUNHA, G.R da; MATZENAUER, R.; PASINATO, A.; PIMENTEL, M.B.M.; CAIAFFO, M.R; PIRES, J.L.F. Zoneamento de riscos climáticos para a cultura de milho no Rio Grande do Sul. Revista Brasileira de Agrometeorologia, v.9, n.3 p. 460-467, 2001. (Número especial: Zoneamento agrícola)

MARCHETTI, V. Risco e decisão em investimento produtivo. Porto Alegre: UFRGS, 1995. 95p.

MARIN, F.R.; SENTELHAS, P.C.; UNGARO, M.R.G. Perda de rendimento potencial da cultura do girassol por deficiência hídrica, no estado de São Paulo. Scientia Agricola, v.57, n.1, p.1-6, 2000.

MASSIGNAM, A.M.; VIEIRA, H.J.; HEMP, S.; DITTRICH, R.C.; FLESCH, R.D.; VICTORIA, F.B. Ecofisiologia do feijoeiro. I Determinação do período mais crítico à deficiência hídrica do solo. Revista Brasileira de Agrometeorologia, v.6, n.1, p.3539, 1998.

MATZENAUER, R.; PONS, A.L.; MALUF, J.R.T.;BUENO, A.C. Efeito da irrigação, adubação e densidade de plantas de milho. I. Rendimento de grãos e componentes do rendimento. In: REUNIÃO TÉCNICA ANUAL DO MILHO, 33., 1988, Porto Alegre. Ata. Porto Alegre: IPAGRO;EMATER, 1989. p.91-100. 
MATZENAUER, R.; BARNI, N.A.; MACHADO, F.A.; ROSA, F.S. da. Análise agroclimática das disponibilidades hídricas para a cultura da soja na região do Planalto Médio do Rio Grande do Sul. Revista Brasileira de Agrometeorologia, v.6, n.2, p.263-275, 1998.

MEDEIROS, R.M. Isoietas mensais e anuais do estado do Piauí. Teresina: Secretaria de Agricultura, Abastecimento e Irrigação, Departamento e Hidrometeorologia, 1996. $24 \mathrm{p}$.

MEIRELES, E.J.L. Utilização do modelo CROPGRO - dry bean na análise de risco climático da cultura do feijoeiro (Phaseolus vulgaris L.) na região de cerrados. Piracicaba, 2000. 105p. Tese (Doutorado) - Escola Superior de Agricultura "Luiz de Queiroz”, Universidade de São Paulo.

MEIRELES, E.J.L.; SILVA, S.C.; ASSAD, E.D.; LOBATO, E.J.V.; BEZERRA, H.S.; EVANGELISTA, B.A.; MOREIRA, L.; CUNHA, M.A.C. Zoneamento agroclimático para o arroz de sequeiro no estado do Tocantins. Goiânia: EMBRAPA, CNPAF, APA, 1995. 72p . (EMBRAPA-CNPAF. Documentos, 58).

MEIRELES, E.J.L.; SILVA, S.C. DA; ASSAD, E.D.; XAVIER, L.S. Caracterização do risco climático na cultura do feijoeiro no estado do Mato Grosso. In: CONGRESSO BRASILEIRO DE AGROMETEOROLOGIA, 10., Piracicaba, 1997a. Anais. Piracicaba: Sociedade Brasileira de Agrometeorologia, 1997a. p.351-353.

MEIRELES, E.J.L.; SILVA, S.C. DA; ASSAD, E.D.; XAVIER, L.S. Estudo espaçotemporal do risco climático no feijoeiro, ciclo de 90 dias, em Goiás. In: CONGRESSO BRASILEIRO DE AGROMETEOROLOGIA, 10., Piracicaba, 1997b. Anais. Piracicaba: Sociedade Brasileira de Agrometeorologia, 1997b. p.348-350. 
MORAIS, A.R. BOTELHO, V.A.V.A.; CARVALHO, L.G. de; MUNIZ, J.A.; LAGE, G. Estimativa da precipitação provável em Lavras(MG) através da distribuição Gama. Revista Brasileira de Agrometeorologia, v.9, n.2, p.305-310, 2001.

NASCIMENTO, J.T.; PEDROSA, M.B.; TAVARES SOBRINHO, J. Efeito da variação de níveis de água disponível no solo sobre o crescimento e produção de feijão caupi, vagens e grãos verdes. Horticultura Brasileira, v.22, n.2, p.174-177, 2004.

NAYLOR, T.H.; BALINTFY, J.L.; TEIXEIRA, E.E. Técnicas de simulação em computadores. Trad. de E.E. Teixeira. Petrópolis: Vozes, 1971. 402p.

NOGUEIRA, L.C.; NOGUEIRA, L.R.Q. Distribuição do sistema radicular de caupi em solo arenoso sob diferentes lâminas de água e doses de adubação fosfatada. Teresina: Embrapa, CPAMN, 1995. 4p. (Embrapa. CPAMN. Pesquisa em Andamento, 62).

OLIVEIRA, D. Evapotranspiração máxima e necessidade de água para irrigação de feijão (Phaseolus vulgaris L.) e trigo (Triticum aestivum L.) determinadas por balanço hídrico para seis locais do Paraná. Piracicaba, 1990. 155p. Dissertação (Mestrado.) Escola Superior de Agricultura “Luiz de Queiroz”, Universidade de São Paulo.

OLIVEIRA, I. P.; CARVALHO, A.M. A cultura do caupi nas condições de clima e solo dos trópicos úmidos e semi-áridos do Brasil. In: ARAÚJO, J. P. P.; WATT, E. E (Org.). O caupi no Brasil. Brasília: IITA;EMBRAPA, 1988. cap. 3, p.63-96.

OLIVEIRA, L.F.C.; CARVALHO, D.F. Regionalização da lâmina suplementar de irrigação e época de plantio da cultura de feijão, no estado de Goiás. Revista Brasileira de Engenharia Agrícola e Ambiental, v.7, n.1, p.106-110, 2003. 
PEITER, M.X. Estudo do manejo da irrigação via modelo de simulação. São Carlos, 1998. 183p. Tese (Doutorado) - Escola de Engenharia de São Carlos, Universidade de São Paulo.

PEREIRA, A.R.; ANGELOCCI, L.R.; SENTELHAS, P.C. Agrometeorologia: fundamentos e aplicações práticas. Guaíba: Agropecuária, 2002. 478p.

PERES, F.C.; MATOS, Z.P.B. Simulação como auxilio a decisão de confinar bovinos de corte. In: SOCIEDADE BRASILEIRA DE ZOOTECNIA. Nova tecnologias de produção animal. Piracicaba : FEALQ, 1990. p.59-70.

PORTO, V.H.F.; CRUZ, E.R.; INFELD, J.A. Metodologia para incorporação de risco em modelos de decisão usados na análise comparativa entre alternativas: o caso da cultura do arroz irrigado. Revista de Economia Rural, v.20, n.2, p.193-211, 1982.

RAO, N.H.; SARMA, P.B.S.; CHANDER, S. A simple dated water-production function for use in irrigated agriculture. Agricultural and Water Management, v.13, p.25-32, 1988.

ROBERTSON, G.P. GS+: geostatistics for the environmental sciences; versão 5.03 beta. Plainwell: Gamma Design Software, 1998. 152p.

RODRIGUES, B.H.N.; ANDRADE JÚNIOR, A.S. de; CARDOSO, M.J.; MELO, F.B.; BASTOS, E.A. Níveis de irrigação sobre a produção de vagens e grãos verdes de feijão caupi (compact disc). In: CONGRESSO BRASILEIRO DE ENGENHARIA AGRÍCOLA, 28., Pelotas, 1999. Anais. Pelotas: SBEA; UFPel, 1999. 
ROLIM, G.S. Ajuste e comparação de modelos de simulação da produtividade para a determinação do risco climático da cultura do girassol (Helianthus annuus L.). Piracicaba, 2000. 125p. Dissertação (Mestrado) - Escola Superior de Agricultura “Luiz de Queiroz”, Universidade de São Paulo.

SALES, M.G.; RODRIGUES, M.A.C. Consumo, qualidade nutricional e métodos de preparo do Caupi... In: ARAÚJO, J. P. P.; WATT, E. E (Org.). O caupi no Brasil. Brasília: IITA;EMBRAPA, 1988. cap. 24, p.697-722

SAMPAIO, S.C.; CORRÊA, M.M.; VILAS BÔAS, M.A.;OLIVEIRA, L.F.C. Estudo da precipitação efetiva para o município de Lavras, MG. Revista Brasileira de Engenharia Agrícola e Ambiental, v.4, n.2, p.210-213, 2000

SANTANA, M. O.; RIBEIRO, A.; SEDIYAMA, G. C. Sistema de geoespacialização da demanda de irrigação suplementar para o estado de Minas Gerais II - Avaliação. Revista Brasileira de Engenharia Agrícola e Ambiental, v.7, n.1, p.64-71, 2003.

SANS, L.M.A.; ASSAD, E.D.; AVELLAR, G.; FARIA, C.M.; SOUZA, L.F. Riscos climáticos para a cultura do milho nos estados de Minas Gerais, Goiás, Tocantins, Mato Grosso e Mato Grosso do Sul. In: CONGRESSO BRASILEIRO DE AGrometeorologiA, 10., Piracicaba, 1997. Anais. Piracicaba: Sociedade Brasileira de Agrometeorologia, 1997. p.357-359.

SANS, L.M.A.; ASSAD, E.D.; GUIMARÃES, D.P.; AVELAR, G. Zoneamento de riscos climáticos para a cultura de milho na Região Centro-Oeste do Brasil e para o estado de Minas Gerais. Revista Brasileira de Agrometeorologia, v.9, n.3, p.527535, 2001. (Número especial: Zoneamento Agrícola). 
SANTOS, C.A.F.; ARAÚJO, F.P.; MENEZES, E.A. Comportamento produtivo de caupi em regimes irrigado e de sequeiro em Petrolina e Juazeiro. Pesquisa Agropecuária Brasileira, v.35, n.11, p.2229-2234, 2000.

SANTOS, J.J.A.; BEZERRA, F.M.L.; MIRANDA, E.P.; CORDEIRO, L.G. Determinação da evapotranspiração de referência (ETo) e evapotranspiração máxima (ETm) em diferentes fases fenológicas do feijão caupi (Vigna unguiculata L. Walp.). In: CONGRESSO BRASILEIRO DE ENGENHARIA AGRÍCOLA, 27., Poços de Caldas, 1998. Anais. Poços de Caldas: SBEA; UFLA, 1998. v.2, p.184-186.

SAUNDERS, L.C.U.; CASTRO, P.T.; BEZERRA, F.M.L.; PEREIRA, A.L.C. Evapotranspiração atual da cultura do feijão-de-corda, Vigna unguiculata (L) Walp., na microrregião homogênea de Quixeramobim, Ceará. Ciência Agronômica, v.16, n. 1, p.75-81, 1985.

SILVA, R.I.; DHEIN, R.A. Viabilização sócio-econômicada rotação de culturas e da adubação verde na COTRIJUÍ. In: REUNIÃO CENTRO-SUL DE ADUBAÇÃO VERDE E ROTAÇÃO DE CULTURAS, 4., 1993, Passo Fundo, RS. Anais. Passo Fundo: Embrapa,CNPT, 1994. p.15-27.

SILVA, S.C. da; MEIRELES, E.J.L.; ASSAD, E.D.; XAVIER, L.S.; CUNHA, M.A.C. Caracterização do risco climático para o arroz de terras altas no estado do Mato Grosso. Goiânia: Embrapa, CNPAF, 1997. 72p. (Embrapa. CNPAF. Documentos, 76).

SILVA, S.C. da; MEIRELES, E.J.L.; XAVIER, L.S.; ALVES, S.F.; BARSI, R.O. Zoneamento agroclimático para o cultivo do feijão da “seca” em Goiás. Santo Antônio de Goiás: Embrapa Arroz e Feijão, 1999. 52p. (Embrapa Arroz e Feijão. Documentos, 94). 
SILVA, W.L.C.; OLIVEIRA, C.A.S.; MORQUELLI, W.A. Subsídios para dimensionamento de sistemas de irrigação. In: CONGRESSO NACIONAL DE IRRIGAÇÃO E DRENAGEM, 8., Florianópolis, 1988. Florianópolis: ABID, 1988. v.1, p.535-553.

SILVEIRA, P.M.; STONE, L.F. Irrigação. In: VIEIRA, C.; PAULA JÚNIOR, T.J.; BORÉM, A. (Ed). Feijão: aspectos gerais e cultura no estado de Minas Gerais. Viçosa: UFV, 1998. 596p.

SILVEIRA, P.M.S.; STONE, L.F. Irrigação do feijoeiro. Santo Antonio de Goiás: Embrapa Arroz e Feijão, 2001. 230 p.

SOUSA, S.A.V. Programa computacional para simulação da ocorrência de veranicos e queda de produção. Piracicaba, 1999. 124p. Tese (Doutorado) - Escola Superior de Agricultura "Luiz de Queiroz", Universidade de São Paulo.

SOUSA, J.R.; QUEIROZ, J.E.; GHEYI, H.R. Variabilidade espacial de características físico-hídricas e de água disponível em um solo aluvial no semi-árido paraibano. Revista Brasileira de Engenharia Agrícola e Ambiental, v.3, n.2, p.140-144, 1999.

SOUSA, S.A.V.; FRIZZONE, J.A. Uso da função triangular na simulação do déficit de evapotranspiração na cultura do fumo em Cruz das Almas, Bahia. In: CONGRESSO BRASILEIRO DE ENGENHARIA AGRÍCOLA, 27., Poços de Caldas, 1998. Anais. Poços de Caldas: SBEA; UFLA, 1998. v.1, p.325-327.

STONE, L.F.; MOREIRA, J.A.A. Resposta do feijoeiro ao nitrogênio em cobertura, sob diferentes lâminas de irrigação e preparos do solo. Pesquisa Agropecuária Brasileira, v.36, n.3, p.473-481, 2001. 
TEÓFILO E.M.; MAMEDE, F.B.F.; SOMBRA, N.S. Hibridação natural em feijão caupi (Vigna unguiculata (L.) Walp - Fabaceae). Ciência e Agrotecnologia, v.23, n.4, p.1010-1011, 1999.

THORNTHWAITE, C.W. An approach toward a rational classification of climate. Geografical Review, v.38, n.1 p.55-94, 1948.

THORNTHWAITE, C.W.; MATHER, J.R. The water balance. New Jersey: Drexel Institute of Technology, 1955. 104p. (Publications in Climatology).

VIEIRA, R.F.; VIEIRA, C.; CALDAS, M.T. Comportamento do feijão-fradinho na primavera-verão na zona da mata de Minas Gerais. Pesquisa Agropecuária Brasileira, v.35, n.7, p.1359-1365, 2000.

WREGE, M.S.; GONÇALVES, S.L.; CARAMORI, P.H.; VASCONCELOS, M.E.C.; OLIVEIRA, D.; ABUCARUB NETO, M.; CAVIGLIONE, J.H. Risco de deficiência hídrica na cultura do feijoeiro durante a safra das águas no estado do Paraná. Revista Brasileira de Agrometeorologia, v.5, n.1, p.51-59, 1997. 
APÊNDICE 
APÊNDICE 1 - Postos Pluviométricos onde foram obtidos os dados diários de precipitação pluviométrica utilizados no estudo, suas posições geográficas e número de anos das séries de dados pluviométricos

\begin{tabular}{|c|c|c|c|c|c|}
\hline $\begin{array}{c}\mathrm{N}^{\mathrm{o}} \\
\text { ordem }\end{array}$ & Posto pluviométrico & $\begin{array}{l}\text { Latitude } \\
\text { (Sul) }\end{array}$ & $\begin{array}{c}\text { Longitude } \\
\text { (Oeste) }\end{array}$ & $\begin{array}{l}\text { Altitude } \\
\text { (m) }\end{array}$ & $\begin{array}{l}\text { Número } \\
\text { de anos }\end{array}$ \\
\hline 1. & Açude Caldeirão & $04^{\circ} 20^{\prime}$ & $41^{\circ} 44^{\prime}$ & 170 & 15 \\
\hline 2. & Alívio & $05^{\circ} 27^{\prime}$ & $41^{\circ} 06^{\prime}$ & 730 & 15 \\
\hline 3. & Alto Alegre & $04^{\circ} 01^{\prime}$ & $41^{\circ} 27^{\prime}$ & 80 & 15 \\
\hline 4. & Alto Bonito & $07^{\circ} 41^{\prime}$ & $44^{\circ} 36^{\prime}$ & 220 & 15 \\
\hline 5. & Alto Parnaíba & $09^{\circ} 08^{\prime}$ & $45^{\circ} 56^{\prime}$ & 220 & 15 \\
\hline 6. & Alto Sereno & $06^{\circ} 59^{\prime}$ & $42^{\circ} 25^{\prime}$ & 160 & 15 \\
\hline 7. & Altos & $05^{\circ} 02^{\prime}$ & $42^{\circ} 28^{\prime}$ & 160 & 15 \\
\hline 8. & Amarante & $06^{\circ} 15^{\prime}$ & $42^{\circ} 51^{\prime}$ & 72 & 15 \\
\hline 9. & Anísio de Abreu & $09^{\circ} 09^{\prime}$ & $42^{\circ} 59^{\prime}$ & 460 & 15 \\
\hline 10. & Arizona & $08^{\circ} 40^{\prime}$ & $40^{\circ} 58^{\prime}$ & 500 & 15 \\
\hline 11. & Aroases & $06^{\circ} 07^{\prime}$ & $41^{\circ} 47^{\prime}$ & 400 & 15 \\
\hline 12. & Assunção & $05^{\circ} 52^{\prime}$ & $41^{\circ} 03^{\prime}$ & 480 & 15 \\
\hline 13. & Barra do Lance & $07^{\circ} 14^{\prime}$ & $43^{\circ} 38^{\prime}$ & 150 & 14 \\
\hline 14. & Barra do Gurgueia & $06^{\circ} 55^{\prime}$ & $43^{\circ} 22^{\prime}$ & 210 & 15 \\
\hline 15. & Barra do Prata & $08^{\circ} 03^{\prime}$ & $44^{\circ} 28^{\prime}$ & 270 & 15 \\
\hline 16. & Barras & $04^{\circ} 15^{\prime}$ & $42^{\circ} 18^{\prime}$ & 75 & 18 \\
\hline 17. & Barreiras do Piauí & $09^{\circ} 57^{\prime}$ & $45^{\circ} 29^{\prime}$ & 500 & 15 \\
\hline 18. & Barroquinha & $02^{\circ} 59^{\prime}$ & $41^{\circ} 05^{\prime}$ & 5 & 15 \\
\hline 19. & Batalha & $04^{\circ} 02^{\prime}$ & $42^{\circ} 05^{\prime}$ & 80 & 20 \\
\hline 20. & Benedítimos (São Benedito) & $05^{\circ} 27^{\prime}$ & $42^{\circ} 20^{\prime}$ & 80 & 15 \\
\hline 21. & Bertolínia (Aparecida) & $07^{\circ} 38^{\prime}$ & $43^{\circ} 57^{\prime}$ & 320 & 15 \\
\hline 22. & Boa Esperança & $08^{\circ} 31^{\prime}$ & $42^{\circ} 27^{\prime}$ & 250 & 15 \\
\hline 23. & Bocaina & $06^{\circ} 54^{\prime}$ & $41^{\circ} 19^{\prime}$ & 250 & 15 \\
\hline 24. & Bom Jardim & $09^{\circ} 21^{\prime}$ & $42^{\circ} 25^{\prime}$ & 600 & 15 \\
\hline 25. & Bom Jesus do Itaueira & $07^{\circ} 05^{\prime}$ & $43^{\circ} 01^{\prime}$ & 95 & 15 \\
\hline 26. & Bom Princípio & $03^{\circ} 15^{\prime}$ & $41^{\circ} 38^{\prime}$ & 50 & 15 \\
\hline 27. & Boqueirão (Codevasf) & $11^{\circ} 20^{\prime}$ & $43^{\circ} 51^{\prime}$ & 2 & 15 \\
\hline 28. & Boqueirão dos Felipes & $09^{\circ} 45^{\prime}$ & $45^{\circ} 40^{\prime}$ & 580 & 15 \\
\hline 29. & Brejo & $09^{\circ} 24^{\prime}$ & $45^{\circ} 14^{\prime}$ & 550 & 15 \\
\hline 30. & Buriti dos Lopes & $03^{\circ} 11^{\prime}$ & $41^{\circ} 52^{\prime}$ & 23 & 15 \\
\hline 31. & Cachoeira do Roberto & $08^{\circ} 38^{\prime}$ & $41^{\circ} 09^{\prime}$ & 630 & 15 \\
\hline 32. & Cambuí & $09^{\circ} 10^{\prime}$ & $46^{\circ} 12^{\prime}$ & 370 & 15 \\
\hline 33. & CampoSanto & $08^{\circ} 19^{\prime}$ & $40^{\circ} 34^{\prime}$ & 34 & 15 \\
\hline 34. & Cantinho & $05^{\circ} 51^{\prime}$ & $42^{\circ} 29^{\prime}$ & 150 & 15 \\
\hline 35. & Canto do Buriti & $08^{\circ} 07^{\prime}$ & $42^{\circ} 57^{\prime}$ & 280 & 15 \\
\hline
\end{tabular}


APÊNDICE 1 - Postos Pluviométricos onde foram obtidos os dados diários de precipitação pluviométrica utilizados no estudo, suas posições geográficas e número de anos das séries de dados pluviométricos (continuação)

\begin{tabular}{|c|c|c|c|c|c|}
\hline $\begin{array}{l}\mathrm{N}^{\mathrm{o}} \\
\text { ordem }\end{array}$ & Posto pluviométrico & $\begin{array}{l}\text { Latitude } \\
\text { (Sul) }\end{array}$ & $\begin{array}{l}\text { Longitude } \\
\text { (Oeste) }\end{array}$ & $\begin{array}{l}\text { Altitude } \\
\text { (m) }\end{array}$ & $\begin{array}{l}\text { Número } \\
\text { de anos }\end{array}$ \\
\hline 36. & Capitão de Campos & $04^{\circ} 28^{\prime}$ & $41^{\circ} 57^{\prime}$ & 120 & 15 \\
\hline 37. & Carnaubal & $04^{\circ} 11^{\prime}$ & $40^{\circ} 58^{\prime}$ & 700 & 15 \\
\hline 38. & Cascavel & $07^{\circ} 29^{\prime}$ & $44^{\circ} 08^{\prime}$ & 350 & 15 \\
\hline 39. & Castelo do Piauí (Marvão) & $05^{\circ} 20^{\prime}$ & $41^{\circ} 34^{\prime}$ & 250 & 15 \\
\hline 40. & Cavalheiro & $09^{\circ} 06^{\prime}$ & $42^{\circ} 23^{\prime}$ & 380 & 15 \\
\hline 41. & Caxingó & $10^{\circ} 31^{\prime}$ & $45^{\circ} 13^{\prime}$ & 500 & 15 \\
\hline 42. & Cícero Coelho & $08^{\circ} 08^{\prime}$ & $44^{\circ} 25^{\prime}$ & 310 & 15 \\
\hline 43. & Cocal & $03^{\circ} 29^{\prime}$ & $41^{\circ} 34^{\prime}$ & 220 & 15 \\
\hline 44. & Conceição & $06^{\circ} 34^{\prime}$ & $42^{\circ} 52^{\prime}$ & 80 & 15 \\
\hline 45. & Conceição do Canindé & $07^{\circ} 54^{\prime}$ & $41^{\circ} 34^{\prime}$ & 249 & 15 \\
\hline 46. & Conceição II & $08^{\circ} 46^{\prime}$ & $44^{\circ} 24^{\prime}$ & 390 & 15 \\
\hline 47. & Corrente & $10^{\circ} 27^{\prime}$ & $45^{\circ} 09^{\prime}$ & 434 & 15 \\
\hline 48. & Cristalândia do Piauí & $10^{\circ} 35^{\prime}$ & $45^{\circ} 17^{\prime}$ & 600 & 15 \\
\hline 49. & Cristino Castro & $08^{\circ} 4^{\prime}$ & $44^{\circ} 13^{\prime}$ & 220 & 17 \\
\hline 50. & Curral Novo & $09^{\circ} 01^{\prime}$ & $41^{\circ} 58^{\prime}$ & 350 & 15 \\
\hline 51. & Curralinho & $06^{\circ} 38^{\prime}$ & $41^{\circ} 17^{\prime}$ & 420 & 15 \\
\hline 52. & Demerval Lobão & $05^{\circ} 22^{\prime}$ & $42^{\circ} 42^{\prime}$ & 102 & 15 \\
\hline 53. & Dico Leopoldino & $05^{\circ} 51^{\prime}$ & $41^{\circ} 23^{\prime}$ & 290 & 15 \\
\hline 54. & Esperantina (Boa Esperança) & $03^{\circ} 54^{\prime}$ & $42^{\circ} 14^{\prime}$ & 50 & 18 \\
\hline 55. & Fartura & $09^{\circ} 22^{\prime}$ & $42^{\circ} 47^{\prime}$ & 520 & 15 \\
\hline 56. & Fauveira & $08^{\circ} 01^{\prime}$ & $43^{\circ} 58^{\prime}$ & 260 & 15 \\
\hline 57. & Fazenda Alegria & $04^{\circ} 41^{\prime}$ & $42^{\circ} 17^{\prime}$ & 190 & 17 \\
\hline 58. & Fazenda Barra & $10^{\circ} 03^{\prime}$ & $45^{\circ} 04^{\prime}$ & 490 & 15 \\
\hline 59. & Fazenda Barreiros & $09^{\circ} 59^{\prime}$ & $44^{\circ} 37^{\prime}$ & 310 & 15 \\
\hline 60. & Fazenda Bela Vista & $09^{\circ} 42^{\prime}$ & $45^{\circ} 23^{\prime}$ & 520 & 15 \\
\hline 61. & Fazenda Boa Esperança & $05^{\circ} 17^{\prime}$ & $41^{\circ} 44^{\prime}$ & 195 & 18 \\
\hline 62. & $\begin{array}{l}\text { Fazenda Boa Vista dos } \\
\text { Cariocas }\end{array}$ & $03^{\circ} 39^{\prime}$ & $42^{\circ} 08^{\prime}$ & 90 & 15 \\
\hline 63. & Fazenda Bom Jardim & $11^{\circ} 01^{\prime}$ & $42^{\circ} 25^{\prime}$ & 600 & 15 \\
\hline 64. & Fazenda Bravo & $07^{\circ} 08^{\prime}$ & $40^{\circ} 54^{\prime}$ & 490 & 15 \\
\hline 65. & Fazenda Bugiu & $08^{\circ} 12^{\prime}$ & $41^{\circ} 58^{\prime}$ & 250 & 15 \\
\hline 66. & Fazenda Campo Alegre & $08^{\circ} 27^{\prime}$ & $44^{\circ} 04^{\prime}$ & 270 & 15 \\
\hline 67. & Fazenda Ipiranga & $05^{\circ} 01^{\prime}$ & $42^{\circ} 05^{\prime}$ & 140 & 15 \\
\hline 68. & Fazenda Lustosa & $04^{\circ} 20^{\prime}$ & $42^{\circ} 33^{\prime}$ & 90 & 15 \\
\hline 69. & Fazenda Macambira & $11^{\circ} 35^{\prime}$ & $44^{\circ} 10^{\prime}$ & 430 & 15 \\
\hline 70. & Fazenda Madeira Cortada & $04^{\circ} 29^{\prime}$ & $41^{\circ} 10^{\prime}$ & 600 & 15 \\
\hline
\end{tabular}


APÊNDICE 1 - Postos Pluviométricos onde foram obtidos os dados diários de precipitação pluviométrica utilizados no estudo, suas posições geográficas e número de anos das séries de dados pluviométricos (continuação)

\begin{tabular}{|c|c|c|c|c|c|}
\hline $\begin{array}{c}\mathrm{N}^{\mathrm{o}} \\
\text { ordem }\end{array}$ & Posto pluviométrico & $\begin{array}{c}\text { Latitude } \\
\text { (Sul) }\end{array}$ & $\begin{array}{c}\text { Longitude } \\
\text { (Oeste) }\end{array}$ & $\begin{array}{l}\text { Altitude } \\
\text { (m) }\end{array}$ & $\begin{array}{l}\text { Número } \\
\text { de anos }\end{array}$ \\
\hline 71. & Fazenda Poço da Pedra & $08^{\circ} 32^{\prime}$ & $40^{\circ} 39^{\prime}$ & 470 & 15 \\
\hline 72. & Fazenda Prevenido & $03^{\circ} 34^{\prime}$ & $41^{\circ} 44^{\prime}$ & 120 & 15 \\
\hline 73. & Fazenda Riacho das Vacas & $08^{\circ} 56^{\prime}$ & $42^{\circ} 18^{\prime}$ & 270 & 15 \\
\hline 74. & Fazenda Riacho Frio & $10^{\circ} 05^{\prime}$ & $44^{\circ} 59^{\prime}$ & 480 & 15 \\
\hline 75. & Fazenda São Domingos & $03^{\circ} 39^{\prime}$ & $41^{\circ} 55^{\prime}$ & 40 & 15 \\
\hline 76. & Fazenda Talhada & $06^{\circ} 53^{\prime}$ & $42^{\circ} 07^{\prime}$ & 160 & 15 \\
\hline 77. & Fazenda Tocaia & $04^{\circ} 35^{\prime}$ & $42^{\circ} 18^{\prime}$ & 120 & 15 \\
\hline 78. & Fazenda Veneza & $05^{\circ} 35^{\prime}$ & $43^{\circ} 02^{\prime}$ & 70 & 18 \\
\hline 79. & Fazenda Ventura & $10^{\circ} 50^{\prime}$ & $42^{\circ} 55^{\prime}$ & 380 & 15 \\
\hline 80. & Fazenda Vitória de Baixo & $03^{\circ} 42^{\prime}$ & $41^{\circ} 59^{\prime}$ & 60 & 15 \\
\hline 81. & Flores do Piauí & $07^{\circ} 49^{\prime}$ & $42^{\circ} 56^{\prime}$ & 270 & 15 \\
\hline 82. & Formosa & $07^{\circ} 34^{\prime}$ & $42^{\circ} 10^{\prime}$ & 230 & 15 \\
\hline 83. & Formosa do Rio Preto & $11^{\circ} 03^{\prime}$ & $45^{\circ} 11^{\prime}$ & 345 & 15 \\
\hline 84. & Francisco Aires & $06^{\circ} 38^{\prime}$ & $42^{\circ} 41^{\prime}$ & 80 & 15 \\
\hline 85. & Fronteiras (Socorro) & $07^{\circ} 05^{\prime}$ & $40^{\circ} 37^{\prime}$ & 418 & 15 \\
\hline 86. & Gado Bravo & $06^{\circ} 56^{\prime}$ & $43^{\circ} 50^{\prime}$ & 180 & 15 \\
\hline 87. & Inhuma & $06^{\circ} 40^{\prime}$ & $41^{\circ} 42^{\prime}$ & 300 & 15 \\
\hline 88. & Itainópolis & $07^{\circ} 24^{\prime}$ & $41^{\circ} 31^{\prime}$ & 210 & 17 \\
\hline 89. & Itaueira & $07^{\circ} 36^{\prime}$ & $43^{\circ} 02^{\prime}$ & 230 & 15 \\
\hline 90. & Jaicos & $07^{\circ} 22^{\prime}$ & $41^{\circ} 08^{\prime}$ & 255 & 15 \\
\hline 91. & Japecanga & $08^{\circ} 44^{\prime}$ & $43^{\circ} 56^{\prime}$ & 240 & 15 \\
\hline 92. & Jenipapeiro & $10^{\circ} 39^{\prime}$ & $45^{\circ} 11^{\prime}$ & 510 & 15 \\
\hline 93. & José de Freitas & $04^{\circ} 45^{\prime}$ & $42^{\circ} 35^{\prime}$ & 130 & 17 \\
\hline 94. & Juscelino Kubistchek & $08^{\circ} 49^{\prime}$ & $42^{\circ} 30^{\prime}$ & 324 & 15 \\
\hline 95. & Lagoa do Sítio & $06^{\circ} 31^{\prime}$ & $41^{\circ} 34^{\prime}$ & 480 & 20 \\
\hline 96. & Landri Sales & $07^{\circ} 16^{\prime}$ & $43^{\circ} 56^{\prime}$ & 240 & 15 \\
\hline 97. & Loreto & $07^{\circ} 05^{\prime}$ & $45^{\circ} 08^{\prime}$ & 170 & 15 \\
\hline 98. & Luíz Correa & $02^{\circ} 53^{\prime}$ & $41^{\circ} 40^{\prime}$ & 10 & 15 \\
\hline 99. & Luzilândia & $03^{\circ} 27^{\prime}$ & $42^{\circ} 22^{\prime}$ & 20 & 14 \\
\hline 100. & Mangabeira & $08^{\circ} 32^{\prime}$ & $44^{\circ} 01^{\prime}$ & 180 & 15 \\
\hline 101. & Matias Olímpio & $03^{\circ} 43^{\prime}$ & $42^{\circ} 33^{\prime}$ & 50 & 15 \\
\hline 102. & Mato Grande & $04^{\circ} 04^{\prime}$ & $42^{\circ} 32^{\prime}$ & 130 & 15 \\
\hline 103. & Miguel Alves & $04^{\circ} 10^{\prime}$ & $42^{\circ} 54^{\prime}$ & 34 & 18 \\
\hline 104. & Monsenhor Gil & $05^{\circ} 35^{\prime}$ & $42^{\circ} 37^{\prime}$ & 120 & 15 \\
\hline 105. & Morais & $07^{\circ} 39^{\prime}$ & $40^{\circ} 24^{\prime}$ & 570 & 15 \\
\hline
\end{tabular}


APÊNDICE 1 - Postos Pluviométricos onde foram obtidos os dados diários de precipitação pluviométrica utilizados no estudo, suas posições geográficas e número de anos das séries de dados pluviométricos (continuação)

\begin{tabular}{|c|c|c|c|c|c|}
\hline $\begin{array}{c}\mathrm{N}^{\mathrm{o}} \\
\text { ordem }\end{array}$ & Posto pluviométrico & $\begin{array}{l}\text { Latitude } \\
\text { (Sul) }\end{array}$ & $\begin{array}{c}\text { Longitude } \\
\text { (Oeste) }\end{array}$ & $\begin{array}{l}\text { Altitude } \\
\text { (m) }\end{array}$ & $\begin{array}{l}\text { Número } \\
\text { de anos }\end{array}$ \\
\hline 106. & Moreira & $08^{\circ} 37^{\prime}$ & $42^{\circ} 08^{\prime}$ & 250 & 15 \\
\hline 107. & Nascente (Olho d'agua) & $07^{\circ} 50^{\prime}$ & $40^{\circ} 27^{\prime}$ & 600 & 15 \\
\hline 108. & Nazaré do Piauí & $06^{\circ} 58^{\prime}$ & $42^{\circ} 40^{\prime}$ & 180 & 15 \\
\hline 109. & Oeiras & $07^{\circ} 01^{\prime}$ & $42^{\circ} 08^{\prime}$ & 170 & 15 \\
\hline 110. & Oitis & $06^{\circ} 22^{\prime}$ & $41^{\circ} 37^{\prime}$ & 270 & 15 \\
\hline 111. & Olho D'água Grande & $04^{\circ} 15^{\prime}$ & $41^{\circ} 17^{\prime}$ & 330 & 15 \\
\hline 112. & Paes Landim & $07^{\circ} 44^{\prime}$ & $42^{\circ} 15^{\prime}$ & 180 & 15 \\
\hline 113. & Palmeirais & $05^{\circ} 58^{\prime}$ & $43^{\circ} 04^{\prime}$ & 85 & 17 \\
\hline 114. & Parnaguá & $10^{\circ} 13^{\prime}$ & $44^{\circ} 38^{\prime}$ & 316 & 15 \\
\hline 115. & Patos & $07^{\circ} 40^{\prime}$ & $41^{\circ} 15^{\prime}$ & 260 & 15 \\
\hline 116. & Pavucu & $07^{\circ} 56^{\prime}$ & $43^{\circ} 13^{\prime}$ & 270 & 15 \\
\hline 117. & Pedro II & $04^{\circ} 25^{\prime}$ & $41^{\circ} 28^{\prime}$ & 580 & 15 \\
\hline 118. & Picos 82780 & $07^{\circ} 04^{\prime}$ & $41^{\circ} 29^{\prime}$ & 208 & 20 \\
\hline 119. & Pio IX (Patrocínio) & $06^{\circ} 50^{\prime}$ & $40^{\circ} 37^{\prime}$ & 550 & 15 \\
\hline 120. & Piracuruca & $03^{\circ} 56^{\prime}$ & $41^{\circ} 43^{\prime}$ & 70 & 16 \\
\hline 121. & Piripiri & $04^{\circ} 17^{\prime}$ & $41^{\circ} 47^{\prime}$ & 160 & 18 \\
\hline 122. & Piripirizinho & $07^{\circ} 25^{\prime}$ & $43^{\circ} 11^{\prime}$ & 230 & 15 \\
\hline 123. & Poranga & $04^{\circ} 44^{\prime}$ & $40^{\circ} 56^{\prime}$ & 700 & 15 \\
\hline 124. & Porto & $03^{\circ} 54^{\prime}$ & $42^{\circ} 43^{\prime}$ & 32 & 18 \\
\hline 125. & Prata do Piauí & $05^{\circ} 40^{\prime}$ & $42^{\circ} 13^{\prime}$ & 80 & 17 \\
\hline 126. & Puca & $08^{\circ} 03^{\prime}$ & $43^{\circ} 39^{\prime}$ & 280 & 15 \\
\hline 127. & Puca II & $08^{\circ} 24^{\prime}$ & $44^{\circ} 24^{\prime}$ & 390 & 15 \\
\hline 128. & Regalo & $09^{\circ} 47^{\prime}$ & $45^{\circ} 02^{\prime}$ & 520 & 15 \\
\hline 129. & Retiro & $04^{\circ} 40^{\prime}$ & $41^{\circ} 28^{\prime}$ & 530 & 15 \\
\hline 130. & Riacho da Mata & $04^{\circ} 56^{\prime}$ & $40^{\circ} 45^{\prime}$ & 290 & 15 \\
\hline 131. & Riacho do Mendes & $07^{\circ} 38^{\prime}$ & $43^{\circ} 40^{\prime}$ & 170 & 15 \\
\hline 132. & Ribeiro Gonçalves & $07^{\circ} 32^{\prime}$ & $45^{\circ} 14^{\prime}$ & 150 & 17 \\
\hline 133. & Saco dos Reis & $07^{\circ} 14^{\prime}$ & $42^{\circ} 11^{\prime}$ & 230 & 15 \\
\hline 134. & Salinas & $08^{\circ} 06^{\prime}$ & $42^{\circ} 34^{\prime}$ & 170 & 15 \\
\hline 135. & Sambaíba & $07^{\circ} 08^{\prime}$ & $45^{\circ} 22^{\prime}$ & 284 & 15 \\
\hline 136. & Sangue & $07^{\circ} 34^{\prime}$ & $44^{\circ} 43^{\prime}$ & 170 & 15 \\
\hline 137. & Santa Cruz do Piauí & $07^{\circ} 09^{\prime}$ & $41^{\circ} 48^{\prime}$ & 170 & 17 \\
\hline 138. & Santa Cruz dos Milagres & $05^{\circ} 49^{\prime}$ & $41^{\circ} 58^{\prime}$ & 80 & 15 \\
\hline 139. & São Félix de Balsas & $07^{\circ} 03^{\prime}$ & $44^{\circ} 59^{\prime}$ & 180 & 15 \\
\hline 140. & São Francisco & $08^{\circ} 24^{\prime}$ & $41^{\circ} 49^{\prime}$ & 370 & 15 \\
\hline
\end{tabular}


APÊNDICE 1 - Postos Pluviométricos onde foram obtidos os dados diários de precipitação pluviométrica utilizados no estudo, suas posições geográficas e número de anos das séries de dados pluviométricos (continuação)

\begin{tabular}{llcccc}
\hline $\begin{array}{c}\mathrm{N}^{\mathrm{o}} \\
\text { ordem }\end{array}$ & Posto pluviométrico & $\begin{array}{c}\text { Latitude } \\
(\text { Sul) }\end{array}$ & $\begin{array}{c}\text { Longitude } \\
(\text { Oeste })\end{array}$ & $\begin{array}{c}\text { Altitude } \\
(\mathrm{m})\end{array}$ & $\begin{array}{c}\text { Número } \\
\text { de anos }\end{array}$ \\
\hline 141. & São Francisco do Piaúi & $07^{\circ} 15^{\prime}$ & $42^{\circ} 33^{\prime}$ & 150 & 15 \\
142. & São João da Serra & $05^{\circ} 30^{\prime}$ & $41^{\circ} 55^{\prime}$ & 180 & 15 \\
143. & São Lourenço & $09^{\circ} 11^{\prime}$ & $42^{\circ} 33^{\prime}$ & 480 & 15 \\
144. & São Miguel do Tapuio & $05^{\circ} 30^{\prime}$ & $41^{\circ} 20^{\prime}$ & 440 & 15 \\
145. & São Pedro & $06^{\circ} 27^{\prime}$ & $41^{\circ} 20^{\prime}$ & 260 & 15 \\
146. & São Pedro do Piauí & $05^{\circ} 56^{\prime}$ & $42^{\circ} 44^{\prime}$ & 190 & 15 \\
147. & São Raimundo Nonato & $09^{\circ} 01^{\prime}$ & $42^{\circ} 41^{\prime}$ & 386 & 15 \\
148. & São Vicente & $05^{\circ} 43^{\prime}$ & $41^{\circ} 42^{\prime}$ & 220 & 15 \\
149. & Serra do Faustino & $08^{\circ} 22^{\prime}$ & $42^{\circ} 36^{\prime}$ & 300 & 15 \\
150. & Serra Vermelha & $07^{\circ} 51^{\prime}$ & $44^{\circ} 10^{\prime}$ & 360 & 15 \\
151. & Serra Vermelha II & $07^{\circ} 56^{\prime}$ & $40^{\circ} 53^{\prime}$ & 280 & 15 \\
152. & Sete Lagoas & $08^{\circ} 27^{\prime}$ & $41^{\circ} 42^{\prime}$ & 380 & 15 \\
153. & Sítio Croata & $07^{\circ} 15^{\prime}$ & $42^{\circ} 20^{\prime}$ & 200 & 15 \\
154. & Sítio Estação & $08^{\circ} 47^{\prime}$ & $42^{\circ} 44^{\prime}$ & 510 & 15 \\
155. & Socorro do Piauí & $07^{\circ} 48^{\prime}$ & $42^{\circ} 30^{\prime}$ & 180 & 15 \\
156. & Tamboril & $07^{\circ} 19^{\prime}$ & $42^{\circ} 47^{\prime}$ & 230 & 15 \\
157. & Tasso Fragoso & $08^{\circ} 28^{\prime}$ & $45^{\circ} 46^{\prime}$ & 191 & 15 \\
158. & Teresina & $05^{\circ} 05^{\prime}$ & $42^{\circ} 49^{\prime}$ & 72 & 17 \\
159. & Tinguis & $03^{\circ} 44^{\prime}$ & $41^{\circ} 59^{\prime}$ & 50 & 14 \\
160. & Tucuns & $07^{\circ} 07^{\prime}$ & $44^{\circ} 20^{\prime}$ & 130 & 15 \\
161. & União & $04^{\circ} 35^{\prime}$ & $42^{\circ} 52^{\prime}$ & 50 & 15 \\
162. & Valença do Piauí (Berlengas) & $06^{\circ} 24^{\prime}$ & $41^{\circ} 45^{\prime}$ & 295 & 15 \\
163. & Várzea Grande & $06^{\circ} 34^{\prime}$ & $42^{\circ} 13^{\prime}$ & 270 & 15 \\
164. & Veados & $06^{\circ} 49^{\prime}$ & $43^{\circ} 30^{\prime}$ & 85 & 15 \\
165. & Vereda da Glória & $09^{\circ} 45^{\prime}$ & $44^{\circ} 52^{\prime}$ & 290 & 15 \\
\hline
\end{tabular}

